American University Washington College of Law

Digital Commons @ American University Washington College of

Law

Articles in Law Reviews \& Other Academic Journals

Scholarship \& Research

2013

Exclusion as a Core Competition Concern

Jonathan Baker

Follow this and additional works at: https://digitalcommons.wcl.american.edu/facsch_lawrev

Part of the Antitrust and Trade Regulation Commons, and the Law and Economics Commons 


\title{
EXCLUSION AS A CORE COMPETITION CONCERN
}

\author{
JONATHAN B. BAKER*
}

Exclusionary conduct ${ }^{1}$ is commonly relegated to the periphery in contemporary antitrust discourse, while price fixing, market division, and other forms of collusion are placed at the core of competition policy. When the term "hard core" is applied to an antitrust violation, ${ }^{2}$ or the "supreme evil" of antitrust is identified, ${ }^{3}$ the reference is invariably to cartels. ${ }^{4}$ At the same time, antitrust is "more cautious" in condemning exclusion than collusion. ${ }^{5}$

* Professor of Law, American University Washington College of Law. This paper revises and extends keynote remarks delivered to the Twenty-second Annual Workshop of the Competition Law and Policy Institute of New Zealand (CLPINZ). The author is especially grateful to Andy Gavil and also indebted to Svend Albaek, Rick Brunell, Peter Carstensen, Pat DeGraba, Aaron Edlin, Harry First, Scott Hemphill, Heather Hughes, Al Klevorick, Prasad Krishnamurthy, Bob Lande, James May, Doug Melamed, Doug Richards, Steve Salop, David Snyder, Josh Soven, Peter Taylor, John Woodbury, Josh Wright, an anonymous referee, and participants in the faculty business law workshop at American University, the law and economics workshop at Berkeley Law School, the CLPINZ workshop, and the Loyola Antitrust Colloquium.

${ }^{1}$ The terms "exclusion" and "foreclosure," which will be used interchangeably, encompass both the complete foreclosure of rivals or potential entrants and conduct that disadvantages rivals without necessarily inducing them to exit. Exclusion is anticompetitive if the excluding firms use it to obtain or maintain market power, as by raising price or keeping a supracompetitive price from declining.

${ }^{2}$ E.g., Organization for Economic Co-Operation and Development, Hard Core CarTELs 58 (2000), available at http://www.oecd.org/dataoecd/39/63/2752129.pdf ("[H]ard core cartels are the most egregious violations of competition law ...."). "Hard core cartels" are collusive arrangements lacking an efficiency justification. See id. at 6. In Europe, the term "hard core" is also applied to a class of prohibited vertical restraints. See Commission Regulation (EU) No. 303/2010, 2010 O.J. (L 102) 1, 4-5 (stating block exemption for vertical agreements not applied to supply or distribution agreements that contain a "hardcore" restriction such as vertical price fixing or territorial or customer sales restrictions).

${ }^{3}$ Verizon Commc'ns Inc. v. Law Offices of Curtis V. Trinko, LLP, 540 U.S. 398, 408 (2004) (noting that collusion is the "supreme evil" of antitrust).

${ }^{4}$ Accord U.S. Dep't of Justice, Antitrust Enforcement and the Consumer 3, available at http://www.justice.gov/atr/public/div_stats/antitrust-enfor-consumer.pdf ("The worst antitrust offenses are cartel violations[.]").

${ }^{5}$ Herbert Hovenkamp, The Antitrust Enterprise 24 (2005); see Leegin Creative Leather Prods., Inc. v. PSKS, Inc., 551 U.S. 877, 888 (2007) (“Our recent cases formulate antitrust principles in accordance with the appreciated differences in economic effect between vertical and horizontal agreements[.]"); Copperweld Corp. v. Independence Tube Corp., 467 U.S.

78 Antitrust Law Journal No. 3 (2013). Copyright 2013 American Bar Association. Reproduced by permission. All rights reserved. This information or any portion thereof may not be copied or disseminated in any form or by any means or downloaded or stored in an electronic database or retrieval system without the express written consent of the American Bar Association. 
Antitrust commentators associated with the Chicago School ${ }^{6}$ have long expressed deep skepticism about exclusion as an antitrust theory, particularly as applied to dominant firm conduct. ${ }^{7}$ Mainstream and progressive commentators also call collusion the central antitrust problem, ${ }^{8}$ although post-Chicago commentators tend more than most to take exclusionary conduct seriously. ${ }^{9}$ Moreover, the antitrust enforcement agencies routinely emphasize collusion over exclusion in articulating their enforcement priorities. ${ }^{10}$ These rhetorical dis-

752, 768 (1984) (“Concerted activity subject to $§ 1$ is judged more sternly than unilateral activity under $§ 2 . ”)$.

${ }^{6}$ The three major eras of antitrust interpretation-classical (1890 to the 1940s), structural (1940s through the 1970s), and Chicago School (since the late 1970s)—and emerging post-Chicago approaches are surveyed in Jonathan B. Baker, A Preface to Post-Chicago Antitrust, in Post-Chicago Developments in Antitrust Law 60, 60-67 (Antonio Cucinotta, Roger Van den Bergh \& Roberto Pardolesi eds., 2002).

${ }^{7}$ In Judge Robert Bork's view, in his influential book The Antitrust Paradox, courts should almost never credit the possibility that a firm could exclude rivals by refusing to deal with suppliers or distributors also or otherwise force rivals to bear higher distribution costs. ROBERT H. Bork, The Antitrust Paradox 156, 346 (1978). However, Bork did identify one case in which he believed that unilateral conduct by a dominant firm had properly been condemned as exclusionary. See id. at 344-46 (citing Lorain Journal Co. v. United States, 342 U.S. 143 (1951)). Judge Richard Posner has similarly described anticompetitive exclusion as "rare," RICHARD PosNER, ANTITRUST LAw 194 (2d ed. 2001), though he is not as skeptical about exclusion as other Chicago School commentators, see id. at 194 \& n. 2.

${ }^{8}$ For example, Professor Herbert Hovenkamp, author of the leading antitrust treatise, recently described price fixing as "kind of the first-degree murder of antitrust violations," Thomas Catan, Critics of E-Books Lawsuit Miss the Mark, Experts Say, Wall St. J., Apr. 23, 2012, at B1, and Professor Robert Lande, a Director of the pro-enforcement American Antitrust Institute, recently called collusion among rivals "the essence of the most evil thing we have in antitrust," Sara Forden, U.S. Sues Apple for eBook Pricing as Three Firms Settle, Bloomberg (Apr. 17, 2012), http://www.bloomberg.com/news/2012-04-17/u-s-sues-apple-for-ebook-pricing-as-three-firmssettle.html.

${ }^{9}$ Professor Steven Salop, a leading post-Chicago antitrust commentator, has long emphasized the importance of antitrust's concern with exclusion. See, e.g., Steven C. Salop, Economic Analysis of Exclusionary Vertical Conduct: Where Chicago Has Overshot the Mark, in How THE Chicago School Overshot the Mark: The Effect of Conservative Economic Analysis on U.S. Antitrust 141, 141-44 (Robert Pitofsky ed., 2008); Thomas G. Krattenmaker \& Steven C. Salop, Anticompetitive Exclusion: Raising Rivals' Costs to Achieve Power Over Price, 96 Yale L.J. 209, 213 (1986). See generally Jonathan B. Baker, Professor of Law, Am. Univ. Wash. Coll. of Law, Remarks at the Presentation of the American Antitrust Institute Antitrust Achievement Award to Steven C. Salop (June 24, 2010), http://www.antitrustinstitute.org/ antitrust/sites/default/files/Baker\%20Salop\%20Comments_062820101005.pdf. Exclusionary conduct has been the source of the most significant divide between Chicago School and postChicago commentators.

${ }^{10} \mathrm{~A}$ recent Assistant Attorney General for Antitrust identified cartel enforcement as his agency's "top priority," well ahead of "single firm conduct" (which often involves exclusion by a dominant firm). See Thomas O. Barnett, Deputy Assistant Att'y Gen. for Antitrust, U.S. Dep't of Justice, Antitrust Enforcement Priorities: A Year in Review (Nov. 19, 2004), available at http:// www.justice.gov/atr/public/speeches/206455.htm. Similarly, it is "uncontroversial," according to a former Chairman of the FTC, that non-merger antitrust enforcement should focus on "horizontal activities" (which are often collusive). Timothy J. Muris, Chairman, Fed. Trade Comm'n, Antitrust Enforcement at the Federal Trade Commission: In a Word-Continuity (Aug. 7, 2001), http://www.ftc.gov/speeches/muris/murisaba.shtm. By "horizontal activities," Muris intended to refer primarily to collusive conduct; he would have used the term "single firm" to discuss most 
tinctions may be framed in terms of traditional doctrinal distinctions between concerted and unilateral conduct, and between horizontal and vertical conduct, but, as Part I of this article explains, they are better understood in terms of the related but not identical economic distinction between collusive and exclusionary conduct.

Exclusion is routinely described as having a lesser priority than collusion even though exclusion is well established as a serious competitive problem in both antitrust law and industrial organization economics. Part II of this article surveys the breadth of practices that courts have considered exclusionary, shows that exclusion has not been downplayed in court decisions, and explains that the emerging doctrinal rules governing exclusion and collusion place the two types of competitive problems on similar footings. In formal structure, antitrust rules are not tougher on collusion. Rather, the rules are tough on conduct with no plausible efficiency justification, i.e., what is commonly termed "naked" collusion or what will be referred to here as "plain" exclusion. Part III demonstrates that collusion and exclusion are also closely related as a matter of economics-so much so as to make the economic reasons for concern about anticompetitive collusion equally reasons for concern about anticompetitive exclusion. If anything, as this Part further explains, anticompetitive exclusion may be the more important problem because of the particular threat exclusion poses to economic growth.

Notwithstanding the broad parallels in the economic analysis of exclusion and collusion, the two types of anticompetitive conduct arise through different economic mechanisms. Just as colluding firms must find a way to solve "cartel problems" (reaching consensus on terms of coordination, deterring cheating on those terms, and preventing new competition), excluding firms must find a way to solve "exclusion problems" (identifying an exclusionary method, excluding sufficient rivals to harm competition, and ensuring that the exclusionary conduct is profitable for each excluding firm). Despite these differences, as Part IV demonstrates, the doctrinal rules identified in Part II truncate the comprehensive reasonableness analysis of exclusionary conduct in ways analogous to the structured reasonableness rules governing collusive conduct by making it unnecessary to show how or whether defendants solve all the relevant exclusion problems or cartel problems. Again, therefore, the

exclusionary behavior. E-mail from Timothy J. Muris, Former Chairman, Fed. Trade Comm'n, to Jonathan Baker, Professor of Law, Am. Univ. Wash. Coll. of Law (Dec. 10, 2011, 7:37 PM EST) (on file with author). Even enforcers "not so aligned with the Chicago School may approach exclusionary claims more cautiously than collusion claims." John Woodbury, Paper Trail: Working Papers and Recent Scholarship, Antitrust Source, Apr. 2012, http://www. americanbar.org/content/dam/aba/publishing/antitrust_source/apr12_papertrail_4_26f.authcheck dam.pdf (referencing Justice Department materials from the current administration). 
formal structure of antitrust rules does not downplay anticompetitive exclusion.

The rhetorical consensus is so powerful that claims of priority for collusion over exclusion are typically stated without explicit justification. They nevertheless appear to be grounded primarily in two commonly accepted and closely related suppositions, evaluated critically in Part V along with other purported justifications for downplaying exclusion. The first supposition is that it is more difficult for courts and enforcers to identify anticompetitive exclusionary conduct than to identify harmful collusive conduct, because conduct that looks exclusionary commonly also promotes competition by enhancing efficiency. ${ }^{11}$ The second is that exclusionary conduct often benefits consumers in the short run, and that as a result, overly aggressive enforcement against exclusionary conduct risks chilling such procompetitive practices as price cutting and new product introductions. Together, these premises, if accepted, would imply that mistakes in enforcement and adjudication against anticompetitive exclusion pose greater threats than mistakes in enforcement and adjudication against anticompetitive collusion, and, consequently, would justify downplaying exclusionary conduct in antitrust enforcement.

Justice Scalia's opinion for the Supreme Court in Verizon Communications Inc. v. Law Offices of Curtis V. Trinko also suggests that mistakes in enforcement and adjudication are more frequent and more troublesome in exclusion cases, but grounds that view in different and more controversial arguments. ${ }^{12}$ The opinion's sweeping rhetoric-all dicta ${ }^{13}$ - minimizes the competitive

${ }^{11}$ See, e.g., U.S. Dep't of Justice, Competition and Monopoly: Single-Firm Conduct Under Section 2 of the Sherman Act 12-13 (2008), available at http://www.justice.gov/atr/ public/reports/236681.pdf, withdrawn, Press Release, U.S. Dep't of Justice, Justice Department Withdraws Report on Antitrust Monopoly Law (May 11, 2009), http://www.usdoj.gov/atr/public/ press_releases/2009/245710.pdf [hereinafter DOJ SEction 2 Report (Withdrawn)]. These themes were also emphasized by speakers at a conference discussion of a draft of this article, including among those sympathetic to a robust antitrust concern with exclusionary conduct.

12 See generally Verizon Commc'ns Inc. v. Law Offices of Curtis V. Trinko, LLP, 540 U.S. 398 (2004). The central claim in the case involved exclusionary conduct: a class of local telephone service customers alleged that Verizon, an incumbent local exchange carrier, had protected its monopoly prices from erosion by denying interconnection services to entrants seeking to offer competing local telephone service. Id. at 402-03 (noting that Verizon was obligated to provide new entrants with interconnection services under the Telecommunications Act of 1996). The Court held that Verizon's unilateral refusal to assist its rivals did not state a claim under the Sherman Act. Id. at 415-16.

${ }^{13}$ Trinko is best read as precluding monopolization liability in a setting in which a separate statutory scheme provides for extensive regulation aimed at promoting competition. (The statute incorporated specific mechanisms for promoting competition by requiring incumbent monopolists to deal with entrants.) See id. at 402-03. If the regulatory scheme is sufficiently extensive and effective, Trinko holds, antitrust enforcement may be displaced. See id. at 413 ("[T]he [regulatory] regime was an effective steward of the antitrust function."); see also Nobody v. Clear Channel Commc'ns, Inc., 311 F. Supp. 2d 1048, 1112-14 (D. Colo. 2004) (limiting Trinko to regulated industry settings). But see John Doe 1 v. Abbott Labs., 571 F.3d 930, 934 (9th Cir. 
concern arising from a monopolist's unilateral exclusionary acts by implicitly describing the consequences of judicial mistakes from Sherman Act Section 2 enforcement in asymmetric terms. ${ }^{14}$ The Trinko opinion can be understood to claim that false negatives (false acquittals) are not troublesome because monopolies are temporary, hence self-correcting; ${ }^{15}$ that false positives (false convictions) are troublesome because monopolies foster economic growth; ${ }^{16}$ and that courts cannot practically craft relief to avoid ongoing judicial supervision, at least with respect to the violation alleged in the case. ${ }^{17}$ Consistent with its skeptical view of antitrust enforcement against exclusionary conduct, Trinko declares that collusion is the "supreme evil" of antitrust ${ }^{18}$ and rhetorically cabins-in an earlier pro-plaintiff monopolization decision, Aspen Skiing Co. v. Aspen Highlands Skiing Corp. ${ }^{19}$ by describing it as "at or near the outer boundary of $\S 2$ liability." 20

Whether the claimed policy justifications for downplaying exclusion are grounded in common ideas about the difficulty distinguishing procompetitive conduct from anticompetitive exclusion or in the more controversial arguments made in Trinko, they do not stand up to analysis. The antitrust enforcement agencies do challenge collusion more frequently than exclusion. This observation could be explained through a theory sympathetic to assigning exclusion a lower priority than collusion, as consistent with the dual suppositions that it is more difficult to rule out efficiencies and avoid erroneous findings of liability in exclusionary conduct cases than in collusive conduct cases. But, as Part V explains, the relatively low frequency of enforcement against anticompetitive exclusion instead probably reflects an enforcement

2009) (considering Trinko outside of the regulated industries context). More recently, the Court again displaced an antitrust court in favor of awarding exclusive jurisdiction over competition enforcement to an industry regulator. Credit Suisse Sec. (USA) LLC v. Billing, 551 U.S. 264 (2007) (expanding the implied antitrust immunity conferred by regulation under the securities laws). See generally Howard A. Shelanski, The Case for Rebalancing Antitrust and Regulation, 109 Мich. L. REv. 683 (2011) (discussing the reasoning and potential consequences of Trinko and Credit Suisse).

14 See Andrew I. Gavil, Exclusionary Distribution Strategies by Dominant Firms: Striking a Better Balance, 72 Antitrust L.J. 3, 42-51 (2004) (offering a detailed exposition and critique of the rhetoric of the majority opinion in Trinko).

15 See Trinko, 540 U.S. at 407.

16 The opinion argues in particular that the prospect of monopoly induces risk-taking and innovation. See id.

17 See id. at 414-15.

${ }^{18} \mathrm{Id}$. at 408.

19472 U.S. 585 (1983).

${ }^{20}$ Trinko, 540 U.S. at 409; accord Pacific Bell Tel. Co. v. linkLine Commc'ns, Inc., 555 U.S. 438, 448 (2009) (dictum) ("[Aspen suggests that] a firm's unilateral refusal to deal with its rivals can give rise to antitrust liability [in] limited circumstances[.]"). Appeals courts have noted the narrow reading that Trinko and linkLine give to Aspen. See, e.g., Broadcom Corp. v. Qualcomm Inc., 501 F.3d 297, 316 (3d Cir. 2007); MetroNet Servs. Corp. v. Qwest Corp., 383 F.3d 1124, 1131-34 (9th Cir. 2004). 
preference for attacking conduct lacking a legitimate justification, combined with the greater frequency of naked collusion relative to plain exclusion when businesses operate in the shadow of antitrust enforcement. Part V also criticizes other policy arguments that have been offered for assigning lesser priority to exclusion, including one based on empirical studies, another rooted in an analysis of institutional competence, and still others suggested by the Supreme Court in Trinko.

The troublesome rhetorical consensus placing exclusionary conduct at antitrust's periphery, not its core, is not just unwarranted; it is damaging. The more that exclusion is downplayed rhetorically, the more that its legitimacy as a subject for antitrust enforcement will be undermined, ${ }^{21}$ so the greater the likelihood that antitrust rules will eventually change to limit enforcement against anticompetitive foreclosure when they should not. Accordingly, anticompetitive exclusion, like anticompetitive collusion, must be understood as a core concern of competition policy.

Part VI of this article discusses the implications for antitrust enforcement of recognizing exclusion as a core concern of competition policy along with collusion. Doing so could lead enforcers to assign a higher priority to attacking exclusion than they do today, particularly challenging conduct foreclosing potential entry in markets subject to rapid technological change. In addition, it would encourage further development of the doctrinal rule governing truncated condemnation of exclusionary conduct in the courts, and protect the rules governing anticompetitive exclusion against pressure for modifications that would limit enforcement.

\section{EXCLUSION AS AN ANTITRUST CATEGORY}

Exclusion and collusion are neither statutory nor doctrinal categories; they are economic categories. The Sherman Act distinguishes between concerted conduct (Section 1) and single-firm behavior (Section 2), ${ }^{22}$ each of which could harm competition through exclusion or collusion..$^{23}$ The doctrinal rules developed to implement both the Sherman Act and the Clayton Act prohibition on anticompetitive mergers distinguish between horizontal and vertical agreements, each of which again could harm competition through exclusion or

\footnotetext{
${ }^{21}$ Cf. Jonathan B. Baker, Preserving a Political Bargain: The Political Economy of the NonInterventionist Challenge to Monopolization Enforcement, 76 ANTITRUST L.J. 605, 625-26 (2010) ("Had Microsoft come out differently, Trinko might have gone farther to question the legitimacy of the antitrust bar on monopolization.").

2215 U.S.C. $\S \S 1-2$. Sherman Act Section 2 also recognizes conspiracy to monopolize, but this statutory provision is rarely invoked.

${ }^{23}$ A single firm could harm competition collusively if a dominant firm fixes prices or divides markets in cooperation with a fringe rival, for example.
} 
collusion. ${ }^{24}$ Although these legal categories continue to play a role in modern antitrust analysis, "today's antitrust lawyers, enforcers and courts focus far more on the nature of the anticompetitive effects, and in private cases, the antitrust injuries, alleged." ${ }^{25}$ For this reason, the antitrust casebook I co-authored "separately groups conduct threatening collusive anticompetitive effects-including traditional horizontal agreements, vertical intrabrand agreements and horizontal mergers-and conduct threatening exclusionary effects-including dominant firm behavior, vertical interbrand restraints and vertical mergers." ${ }^{26}$ In making this distinction, the casebook adopted the major structural division employed by Judge Posner in his antitrust treatise and his co-authored antitrust casebook. ${ }^{27}$

Although exclusionary claims are most commonly framed as challenges to vertical agreements or monopolization, antitrust's traditional doctrinal categories do not perfectly track the distinction between exclusion and collusion. Vertical conduct is not invariably exclusionary. Agreements between manufacturers and distributors, for example, may harm competition by facilitating collusion at either level as well as by excluding entrants into manufacturing or distribution..$^{28}$ Nor is horizontal conduct invariably collusive. The category includes, for example, exclusionary group boycotts. ${ }^{29}$

${ }^{24}$ The Sherman Act also distinguishes between exclusionary and exploitative conduct. See United States v. Grinnell Corp., 384 U.S. 563, 570-71 (1966) (noting that the exercise of market power by a firm that obtained it "as a consequence of a superior product, business acumen, or historic accident" is not actionable as monopolization). But see Einer Elhauge, Tying, Bundled Discounts, and the Death of the Single Monopoly Profit Theory, 123 HARv. L. Rev. 397, 420-26 (2009) (arguing that the Supreme Court's tying jurisprudence is predicated in part on recognition of the exploitation of monopoly power as a basis for liability). By contrast, in the European approach to competition policy, a dominant firm can be found to have abused its position through exploitative offenses such as charging higher prices, though such cases are rare. THE EC LAW OF Competition $\$ \S 4.358-361$ (Jonathan Faull \& Ali Nikpay eds., 2d ed. 2007). It is an open question whether exploitative conduct could be reached as a violation of FTC Act Section 5 .

25 Andrew I. Gavil, William E. Kovacic \& Jonathan B. Baker, Antitrust Law in Perspective: Cases, Concepts and Problems in Competition Policy vii (2d ed. 2008) [hereinafter Antitrust Law in Perspective]. Although modern antitrust emphasizes effects, the Sherman Act's agreement requirement means that the statute does not reach every instance in which firms harm competition through coordination. See Jonathan B. Baker, Two Sherman Act Section 1 Dilemmas: Parallel Pricing, the Oligopoly Problem, and Contemporary Economic Theory, 38 Antitrust Bull. 143 (1993).

${ }^{26}$ Antitrust Law in Perspective, supra note 25, at vii. The doctrinal categories are grouped based on whether the harm to competition addressed in the leading cases more commonly results from exclusion or collusion, but all the practices could harm competition either way.

27 See Posner, supra note 7; Richard A. Posner \& Frank H. Easterbrook, Antitrust: Cases, Economic Notes and Other Materials (2d ed. 1981); $c f$. Bork, supra note 7, at 134 (describing collusive and exclusionary conduct as "two theories of the ways in which competition may be injured that ... shape and drive the law").

${ }^{28}$ See Leegin Creative Leather Prods., Inc. v. PSKS, Inc., 551 U.S. 877, 892-94 (2007) (discussing both collusive and exclusionary explanations for resale price maintenance).

${ }^{29}$ E.g., Nw. Wholesale Stationers, Inc. v. Pac. Stationery \& Printing Co., 472 U.S. 284 (1985). 
The antitrust rules most closely associated with exclusion-those governing the conduct of monopolists and would-be monopolists, and vertical agreements-have long been among the most controversial in U.S. competition policy; the antitrust norms in these categories have aptly been described as "contested." ${ }^{30}$ Over the course of antitrust history, the Supreme Court has repeatedly altered its approach to evaluating the legality of vertical non-price restraints. ${ }^{31}$ The modern legal rule nearly inverts the rule applied forty-five years ago. ${ }^{32}$ The standard used to test vertical agreements concerning price has been even less consistent, ${ }^{33}$ and remains contested, ${ }^{34}$ although the case law did not explicitly associate resale price maintenance with exclusion until recently. ${ }^{35}$ A switch of one vote would have led the Supreme Court to abandon the longstanding per se prohibition against tying. ${ }^{36}$ Monopolization standards

${ }^{30}$ William E. Kovacic, The Modern Evolution of U.S. Competition Policy Enforcement Norms, 71 Antitrust L.J. 377, 410 (2003) (describing as "contested" the antitrust norms governing "abuse of dominance and vertical contractual restraints" between 1961 and 2000). Kovacic sees different patterns in the evolution of norms developed in other areas of antitrust: "progressive contraction (Robinson-Patman matters), progressive expansion (criminal and civil horizontal restraints), [or] contraction followed by stabilization (mergers) . . .." Id.

${ }^{31}$ See, e.g., Richard A. Posner, The Next Step in the Antitrust Treatment of Restricted Distribution: Per Se Legality, 48 U. CHI. L. Rev. 6, 6 (1981) (noting that between 1963 and 1976, the legality of (non-price) distribution restrictions "oscillated from the Rule of Reason to per se illegality and back").

${ }^{32}$ The Court adopted a rule of per se illegality in 1967, in United States v. Arnold, Schwinn \& Co., 388 U.S. 365 (1967), but overruled that decision in favor of applying the rule of reason ten years later, in Continental T.V., Inc. v. GTE Sylvania Inc., 433 U.S. 36 (1977). Since 1977, vertical non-price restraints have rarely been prohibited, leading one commentator to describe the practical standard as close to per se legality. See Douglas H. Ginsburg, Vertical Restraints: De Facto Legality Under the Rule of Reason, 60 AnTitRust L.J. 67 (1991).

${ }^{33}$ Since vertical restraints on price were held illegal per se in Dr. Miles Medical Co. v. John D. Park \& Sons Co., 220 U.S. 373 (1911), Congress authorized states to allow such agreements (see Miller-Tydings Act, Pub. L. No. 314, 50 Stat. 693 (1937)), then broadened that authority (see McGuire Act, Pub. L. No. 542, 66 Stat. 631 (1952)), and then returned the law to the rule of per se illegality by repealing its authorization (see Consumer Goods Pricing Act of 1975, Pub. L. No. 94-145, 89 Stat. 801). More recently, the Supreme Court overruled Dr. Miles and adopted the rule of reason. Leegin, 551 U.S. at 907.

${ }^{34}$ The Leegin decision drew a passionate dissent from four Justices. See id. at 908 (Breyer, J., dissenting). One month before the oral argument, an FTC Commissioner issued an unusual public statement detailing her disagreement with the Solicitor General's pro-defendant brief. See Letter from Pamela Jones Harbour, Commissioner, Fed. Trade Comm'n, to the Supreme Court of the United States (Feb. 26, 2007), available at http://www.ftc.gov/speeches/harbour/070226verticalminimumpricefixing.pdf. The continuing controversy over resale price maintenance in the wake of Leegin is discussed in Andrew Gavil, Resale Price Maintenance in the Post-Leegin World: A Comparative Look at Recent Developments in the United States and European Union, CPI Antitrust J., Summer 2010, Vol. 6, No. 1.

${ }^{35}$ See Leegin, 551 U.S. at 892-94 (discussing both collusive and exclusionary explanations for resale price maintenance).

${ }^{36}$ See Jefferson Parish Hosp. Dist. No. 2 v. Hyde, 466 U.S. 2 (1984) (5-4 decision). However, courts have found ways to avoid applying the per se prohibition when tying may promote competition. See, e.g., United States v. Microsoft Corp., 253 F.3d 34, 89-95 (D.C. Cir. 2001) (en banc). See generally 1 ABA Section of Antitrust Law, Antitrust Law Developments 201-04 
are also controversial, as is evident from a debate between the federal antitrust enforcement agencies early in the 21 st century. ${ }^{37}$

From a contemporary perspective that recognizes the central role economic concepts now play in antitrust, the controversies over monopolization and vertical restraints standards are best understood as proxy battles over the appropriate treatment of exclusionary conduct. ${ }^{38}$ This interpretation draws an economic distinction between exclusion and collusion in preference to the statutory distinction between single firm conduct and agreements, and the doctrinal distinction between horizontal agreements on the one hand and vertical agreements and monopolization on the other.

As antitrust has come to focus on economic distinctions in preference to doctrinal pigeonholes, exclusion has become an important and controversial antitrust category. For this reason, the next Part looks across doctrinal categories in identifying common themes in the judicial approach to exclusionary conduct.

\section{EXCLUSION IN ANTITRUST CASE LAW AND DOCTRINE}

The rhetorical consensus downplaying the significance of exclusionary conduct is surprising because anticompetitive exclusion is treated by antitrust law as a serious competitive problem. A number of leading U.S. antitrust decisions, including recent ones, have been concerned primarily with exclusionary conduct. Microsoft made it difficult for Netscape to market its browsers to computer users in order to protect its Windows operating system monopoly from the competition that would be created if software applications could access any operating system through the browser. ${ }^{39}$ Standard Oil exploited its leverage over the railroads to stop the entry of new refiners in order to protect its monopoly in oil refining..$^{40}$ Before AT\&T (the Bell System) was broken up,

(7th ed. 2012) [hereinafter Antitrust Law Developments]; Herbert Hovenkamp, Federal Antitrust Policy: The Law of Competition and Its Practice $§ 10.7$ a (4th ed. 2011).

${ }^{37}$ During the George W. Bush administration, the Justice Department encouraged courts to adopt a doctrinal approach that would favor defendants, but the Federal Trade Commission pointedly refused to go along. At the start of the Obama administration, the Justice Department withdrew the previous administration's proposal. See Baker, supra note 21, at 606-07.

${ }^{38}$ See Posner, supra note 7, at 4 (arguing that the economic theory of monopoly had much more to say about collusive practices than exclusionary ones, leading some economists and lawyers identified with the Chicago School (but not Posner) to the view "that there was no economic basis for concern with the exclusionary practices"). But see Bus. Elecs. Corp v. Sharp Elecs. Corp., 485 U.S. 717, 747-48 (1988) (Stevens, J., dissenting) (explaining the majority opinion as turning, without justification, on treating the distinction between horizontal and vertical agreements as more important than the distinction between collusive and exclusionary conduct).

${ }^{39}$ Microsoft, 253 F.3d at 64-67.

40 United States v. Standard Oil, 221 U.S. 1 (1911). See generally Elizabeth Granitz \& Benjamin Klein, Monopolization by "Raising Rivals Costs": The Standard Oil Case, 39 J.L. \& Econ. 1 (1996). Compare George L. Priest, Rethinking the Economic Basis of the Standard Oil Refining 
it maintained market power in unregulated markets for specialized telephone service and customer premises equipment by discriminating against rivals that sought to connect with its regulated local telephone service monopoly. ${ }^{41}$ Visa and MasterCard prevented member banks from issuing American Express and Discover cards in order to protect their own market power. ${ }^{42}$

Exclusionary conduct allegations are also central to other antitrust decisions commonly thought of as alleging collusion. The NCAA threatened two large state universities with disciplinary action if they did not comply with the NCAA's arrangement for broadcasting college football games. ${ }^{43}$ Dentists that did not comply with the advertising restrictions promulgated by the California Dental Association could be censured or expelled. ${ }^{44}$ The National Society of Professional Engineers encouraged state societies to launch disciplinary proceedings against engineers that did not comply with its ethical code, which included the challenged restrictions on competitive bidding restrictions. ${ }^{45}$ The predatory conspiracies alleged (but ultimately not demonstrated) in Brooke Group and Matsushita were said to have excluded generic cigarettes and a U.S. firm manufacturing televisions, respectively. ${ }^{46}$ The horizontal (collusive) market division agreement attacked in Topco allowed the firms to prevent their rivals from selling the cooperative's private label products. ${ }^{47}$ The nearly two hundred insurance companies indicted for price fixing during the early 1940s were also accused of employing boycotts, coercion, and intimidation to prevent competition from firms that were not members of their trade association. $^{48}$

During the modern era, moreover, the Supreme Court and the appellate courts have addressed exclusionary conduct without consistently favoring ei-

\footnotetext{
Monopoly: Dominance Against Competing Cartels, 85 S. CAL. L. Rev. 499 (2012) (questioning some of Granitz \& Klein's argument), with Benjamin Klein, The "Hub-and-Spoke" Conspiracy that Created the Standard Oil Monopoly, 85 S. CAL. L. Rev. 459 (2012) (responding to Priest).

${ }^{41}$ See United States v. AT\&T, 552 F. Supp. 131, 162, 170 (D.D.C. 1982) (entering consent decree requiring divestitures), aff'd, 714 F.2d 178 (D.C. Cir. 1983).

42 United States v. Visa U.S.A., Inc., 344 F.3d 229, 240 (2d Cir. 2003).

${ }^{43}$ NCAA v. Bd. of Regents of the Univ. of Okla., 468 U.S 85, 85 (1984).

${ }^{44}$ Cal. Dental Ass'n v. FTC, 526 U.S. 756 (1959).

${ }^{45}$ United States v. Nat'l Soc'y of Prof'l Eng'rs, 389 F. Supp. 1193, 1210 (D.D.C. 1974), aff'd 555 F.2d 978 (D.C. Cir. 1977), aff'd 435 U.S. 679 (1978).

${ }^{46}$ Brooke Grp. Ltd. v. Brown \& Williamson Tobacco Corp., 509 U.S. 209 (1993); Matsushita Elec. Indus. Co., v. Zenith Radio Corp., 475 U.S. 574 (1986). Brooke Group was arguably decided incorrectly. See Jonathan B. Baker, Predatory Pricing after Brooke Group: An Economic Perspective, 62 Antitrust L.J. 585, 598 (1994) ("[T]he Court took the case from the jury to award judgment to the defendant when the record on this key question of fact, construed favorably to plaintiff, arguably supported plaintiff's position.").

${ }^{47}$ United States v. Topco Assocs., 405 U.S. 596 (1972). See generally Peter C. Carstensen \& Harry First, Rambling Through Economic Theory: Topco's Closer Look, in AnTITRUST STORIES 171, 171-204 (Eleanor M. Fox \& Daniel A. Crane eds., 2007).

48 United States v. South-Eastern Underwriters Ass'n, 322 U.S. 533, 535-36 (1944).
} 
ther defendants or plaintiffs. ${ }^{49}$ Looking to outcome, reasoning, and tone, decisions of the courts of appeals during the first half of 2011 (an arbitrarily chosen recent period), ${ }^{50}$ as well as notable decisions of the circuit courts and the Supreme Court from the past three decades,,${ }^{51}$ do not systematically favor either side.

To show how seriously the courts take exclusionary conduct, this article adopts two approaches. Part II.A documents the wide range of exclusionary conduct that the courts have evaluated. This informal survey shows that anticompetitive exclusion has not been downplayed by the courts through limitation to a narrow range of practices, contrary to what the rhetoric of enforcers and commentators might suggest.

Part II.B identifies parallels in the formal structure of the emerging doctrinal rules employed by the courts to identify anticompetitive exclusionary and anticompetitive collusive conduct. In particular, the courts have evolved a similar approach to the two doctrinal areas: adopting a presumption in each against conduct lacking a plausible efficiency justification. Although these

\footnotetext{
${ }^{49}$ The relative success of plaintiffs and defendants is difficult to interpret because it may depend on a variety of factors beyond the general attitude of the courts, including whether legal rules are changing, the willingness of firms to engage in questionable conduct that could be challenged, and the willingness of the parties to a lawsuit to litigate rather than settle. Accordingly, even a consistently one-sided pattern of decisions may be a poor indicator of judicial attitudes toward exclusionary conduct.

${ }^{50}$ During this period, arguably pro-enforcement exclusion decisions were issued by circuit courts of appeals in Watson Carpet \& Floor Covering, Inc. v. Mohawk Industries, Inc., 648 F.3d 452 (6th Cir. 2011), E.I DuPont de Nemours \& Co. v. Kolon Industries, Inc., 637 F.3d 435 (4th Cir. 2011), and Realcomp II, Ltd. v. FTC, 635 F.3d 815 (6th Cir. 2011), while arguably noninterventionist exclusion decisions were issued in Southeast Missouri Hospital v. C.R. Bard Inc., 642 F.3d 608 (8th Cir. 2011), Brantley v. NBC Universal, Inc., 649 F.3d 1078 (9th Cir. 2011), and Smugglers' Notch Homeowners Association v. Smugglers' Notch Management Co., 414 F. App'x 372 (2d Cir. 2011).

${ }_{51}$ The Supreme Court exclusion decisions listed below more often take the non-interventionist side, exclusively so since 1993, but the circuit courts do not appear to have interpreted the recent pattern as a mandate to raise the bar to plaintiffs in exclusion cases. Notable decisions from the Supreme Court and appellate courts arguably on the pro-enforcement side of the ledger include Eastman Kodak Co. v. Image Technical Services, Inc., 504 U.S. 451 (1992); Aspen Skiing Co. v. Aspen Highlands Skiing Corp., 472 U.S. 585 (1983); Spirit Airlines, Inc. v. Northwest. Airlines, Inc., 431 F.3d 917 (6th Cir. 2005); United States v. Dentsply International, Inc., 399 F.3d 181 (3d Cir. 2005); United States v. Visa, 344 F.3d 229 (2d Cir. 2003); LePage's Inc. v. 3M, 324 F.3d 141 (3d Cir. 2003); United States v. Microsoft Corp., 253 F.3d 34 (D.C. Cir. 2001) (en banc); and JTC Petroleum Co. v. Piasa Motor Fuels, Inc., 190 F.3d 775 (7th Cir. 1999). Notable decisions arguably on the non-interventionist side include Pacific Bell Telephone Co. v. linkLine Communications, Inc., 555 U.S. 438 (2009); Verizon Communications Inc. v. Law Offices of Curtis V. Trinko, LLP, 540 U.S. 398, 408 (2004); Brooke Group Ltd. v. Brown \& Williamson Tobacco Corp., 509 U.S. 209 (1993); Spectrum Sports, Inc. v. McQuillan, 506 U.S. 447 (1993); Matsushita Electric Industrial Co, v. Zenith Radio Corp., 475 U.S. 574 (1986); Jefferson Parish Hospital District No. 2 v. Hyde, 466 U.S. 2 (1984); Cascade Health Solutions v. PeaceHealth, 515 F.3d 883 (9th Cir. 2008); E\&L Consulting, Ltd. v. Doman Industries Ltd., 472 F.3d 23 (2d Cir. 2006); United States v. AMR Corp., 335 F.3d 1109 (10th Cir. 2003); and Omega Environmental, Inc. v. Gilbarco, Inc., 127 F.3d 1157 (9th Cir. 1997).
} 
presumptions are invoked more frequently in collusion cases than exclusion cases, the difference is attributable to the greater frequency with which antitrust enforcers and private plaintiffs challenge facially anticompetitive collusion, and not to any difference in how tough the rules are when the two types of anticompetitive conduct are identified. Part II.C explains why those structural parallels will remain as courts clarify open questions regarding the emerging truncated rule governing exclusionary conduct.

\section{A. Exclusionary Practices Identified by the Courts}

The courts do not treat anticompetitive exclusion as an unusual event; instead they have recognized that exclusionary conduct harming competition can take a wide range of forms..$^{52}$ The anticompetitive possibilities surveyed have been divided into three broad categories based on the mechanism by which exclusion takes place, with an eye toward the economic analysis in Part III. ${ }^{53}$ In general, these practices are neither necessarily nor invariably anticompetitive, as rivals could be excluded without harm to competition, and practices that exclude rivals could help firms lower costs, improve products, or otherwise achieve efficiencies as well as helping them obtain or maintain market power. The survey is not intended as an inventory of all possible means of exclusion; rather, it is intended to illustrate the breadth of conduct that could harm competition through foreclosure.

The practices described in the first two categories exclude rivals by imposing a constraint on the latter firms' conduct, as by raising rivals' costs or, to similar effect, reducing rivals' access to customers. ${ }^{54}$ The methods in the first category can be undertaken by the excluding firms acting alone, whether through the unilateral action of a single excluding firm or the joint action of a group of excluding firms. The methods in the second category require the excluding firms to coordinate with firms that are not rivals through the purchase of an exclusionary right. Because coordination is required, the profitability of practices in the second category turns in part on factors not relevant to the profitability of practices in the other categories, as discussed below in Part IV.B. In the third category, the excluding firms discourage competition

\footnotetext{
52 See generally Richard M. Steuer, Foreclosure, in 2 ABA Section of Antitrust Law, Issues in Competition Law and Policy 925, 926-29 (Wayne Dale Collins ed., 2008) (surveying case law).

${ }^{53}$ For an alternative classification scheme more closely tied to familiar doctrinal categories, see Scott Hemphill \& Tim Wu, Parallel Exclusion, 122 YALE L.J. 1182 (2013) (identifying six mechanisms of foreclosure: simple exclusion, recruiting agents, overbuying an input, tying and bundling, resale price maintenance, and most favored nations provisions).

${ }^{54}$ Input foreclosure strategies are commonly thought of as raising rivals' costs while customer foreclosure strategies are commonly thought of as limiting rivals' access to the market, but customer foreclosure strategies can also be understood as another form of raising rivals' costs because they raise rivals' costs of distribution.
} 
by altering their rivals' incentives, in particular by credibly threatening the rivals with harm should the latter firms seek to compete aggressively.

\section{Constraints Imposed on Rival Conduct}

The most obvious anticompetitive exclusionary strategies directly constrain rivals by imposing costs or reducing rivals' access to customers. A dominant firm might destroy a fringe rival's distribution facilities, ${ }^{55}$ or obtain a monopoly position through fraudulent acquisition of a patent. ${ }^{56}$ To similar effect, a vertically integrated dominant firm could redesign its upstream product in order to create an incompatibility for its downstream rival. ${ }^{57}$ A firm may also directly exclude its rivals by failing to disclose in advance its patent

\footnotetext{
55 See Conwood Co. v. U.S. Tobacco Co., 290 F.3d 768, 778 (6th Cir. 2002) (discussing a dominant manufacturer of snuff that excluded a fringe rival by destroying its rival's in-store display racks); Kenneth P. Brevoort \& Howard P. Marvel, Successful Monopolization Through Predation: The National Cash Register Company, 21 Res. IN L. \& Econ. 85 (John B. Kirkwood ed., 2004) (discussing a dominant firm maintained its monopoly power in part through espionage and sabotage; federal criminal prosecution settled by consent). Allegedly tortious conduct accompanied a restriction on access to supply in Watson Carpet \& Floor Covering, Inc. v. Mohawk Industries, Inc., 648 F.3d 452, 455 (6th Cir. 2011), which involved "false derogatory accusations about [the excluded firm to] potential customers[.]" See also Nat'l Ass'n of Pharm. Mfrs., Inc. v. Ayerst Labs., 850 F.2d 904, 916 (2d Cir. 1988) (noting that dominant firm's public statements disparaging rival's product would support monopolization claim if "(1) clearly false, (2) clearly material,[ and] (3) clearly likely to induce reasonable reliance"); Int'l Travel Arrangers, Inc. v. W. Airlines, Inc., 623 F.2d 1255, 1262 (8th Cir. 1980) (dominant firm's exclusionary conduct included a false, misleading, and deceptive newspaper ad). Managers at one pizza chain were recently charged with arson after allegedly burning down a rival's nearby store in order to increase sales, though no antitrust violation was apparently charged. Florida Domino's Managers Charged with Burning Down Rival Pizza Parlor, FoxNews.com (Oct. 29, 2011), http://www.fox news.com/us/2011/10/29/florida-dominos-managers-charged-with-burning-down-rival-pizzaparlor/print\#ixzz1d1mfXJ3B. Business torts can exclude rivals without harming competition, though, and thus do not necessarily also constitute violations of the antitrust laws.

${ }^{56}$ Walker Process Equip., Inc. v. Food Mach. \& Chem. Corp., 382 U.S. 172 (1965).

${ }^{57}$ E.g., C.R. Bard, Inc. v. M3 Sys., Inc., 157 F.3d 1340, 1382-83 (Fed. Cir. 1998). A deceptive misrepresentation concerning incompatibility may similarly harm competition if believed. See Joseph Farrell, Janis K. Pappalardo \& Howard Shelanski, Economics at the FTC: Mergers, Dominant-Firm Conduct, and Consumer Behavior, 37 Rev. Indus. Org. 263, 268 (2010) (describing the FTC complaint against Intel resolved by consent settlement as based in part on this theory).
} 
rights in a technology adopted as an industry standard, ${ }^{58}$ engaging in sham litigation, ${ }^{59}$ or manipulating a regulatory scheme. ${ }^{60}$

Other methods by which firms can impose constraints that exclude rivals may be less direct but equally harmful. A vertically integrated dominant firm can refuse to sell a key input to rivals, ${ }^{61}$ or degrade the quality of the input it provides, as by refusing to sell the highest quality inputs. ${ }^{62} \mathrm{~A}$ vertical merger may threaten anticompetitive exclusion by conferring an incentive for the merged firm unilaterally to foreclose upstream rivals from access to distribution (customer foreclosure) or unilaterally to foreclose downstream rivals from access to a key input (input foreclosure). ${ }^{63}$ A dominant firm can exclude its rivals by refusing to deal with their suppliers, thereby discouraging the suppliers from dealing with competing firms. ${ }^{64}$ A dominant firm that sells complementary products can take customers away from an unintegrated rival, thereby reducing the rival's scale of operations and so raising its costs. The dominant firm can also accomplish the same end by tying complementary products together, ${ }^{65}$ offering discounts to buyers purchasing a package of

\footnotetext{
${ }^{58}$ Several related exclusion scenarios are suggested by the case law. All suppose that a standard-setting organization (SSO) selects a particular technology owned by one firm in preference to alternative technologies, conditional on a representation by the firm that it does not have intellectual property covering the standard or that it will abide by a commitment to license on a non-discriminatory basis and charge reasonable royalties if the technology is selected. After the technology is incorporated into the standard, and firms adopting the standard make sunk investments to use it (become locked-in), the firm owning the technology acts inconsistently with its commitment, as by asserting intellectual property rights and charging royalties (see Dell Computer Corp., 121 F.T.C. 616 (1996)), charging unreasonably high royalties, or preventing firms from using its intellectual property if they compete with it in the sale of products that incorporate the standard. See Broadcom Corp. v. Qualcomm Inc., 501 F.3d 297, 316 (3d Cir. 2007).

${ }^{59}$ Cal. Motor Transp. Co. v. Trucking Unlimited, 404 U.S. 508 (1972).

${ }^{60}$ In re K-Dur Antitrust Litig., 686 F.3d 197 (3d Cir. 2012).

${ }^{61}$ E.g., Aspen Skiing Co. v. Aspen Highlands Skiing Corp., 472 U.S. 585 (1985) (firm controlling three of the four mountains at a leading destination ski resort excluded the company owning the fourth mountain from participating in a multi-area ski ticket, making it difficult for the excluded firm to attract customers scheduling week-long ski vacations).

${ }^{62}$ Bell Atl. Corp. v. Twombly, 550 U.S. 544 (2007) (major local telephone companies, which had different territorial footprints, allegedly acted in concert to evade their statutory obligation to interconnect with new rivals by making interconnection costly and cumbersome or providing low quality connections).

${ }^{63}$ Applications of Comcast Corporation, General Electric Company, and NBC Universal, Inc., For Consent to Assign Licenses and Transfer Control of Licensees, Memorandum Opinion and Order, 26 FCC Rcd. 48 (2011) (noting that Comcast could disadvantage rival video distributors by denying them access to NBC programming or raising the price, and disadvantage rival programming suppliers by denying them access to Comcast's video distribution customers or charging them more), available at transition.fcc.gov/FCC-11-4.pdf.

${ }^{64}$ Lorain Journal Co. v. United States, 342 U.S. 143 (1951) (monopolist newspaper refused to accept ads from firms that advertised on a new radio station).

${ }^{65}$ See Eastman Kodak Co. v. Image Technical Servs., Inc., 504 U.S. 451 (1992) (Kodak allegedly tied copier parts to copier service in order to exclude independent service operators). Tying or bundling may be employed as an exclusionary strategy. See, e.g., Dennis W. Carlton \& Michael Waldman, The Strategic Use of Tying to Preserve and Create Market Power in Evolving
} 
products, ${ }^{66}$ or offering discounts to buyers based on the share of the buyer's total input purchases accounted for by the excluding seller. ${ }^{67}$ Similar exclusionary strategies to those set forth above could be employed by a group of excluding firms acting collectively to harm a rival, as through an exclusionary group boycott, ${ }^{68}$ parallel exclusionary conduct, ${ }^{69}$ or pooling weak patents. ${ }^{70}$

\section{Purchase of an Exclusionary Right}

The exclusionary strategies in the second category require the involvement of non-excluding firms to raise rivals' costs, as through vertical agreement. A firm can foreclose its rivals by contracting with sellers of key inputs, inexpensive distribution, or other complementary products or services to raise the price that rivals must pay for the complement or to deny rivals access to that product entirely. ${ }^{71} \mathrm{~A}$ dominant firm may also employ other contracting strategies to raise rivals' costs. It may overbuy a key input to bid up the market

Industries, 33 RAND J. ECON. 194, 209 (2002); John Simpson \& Abraham L. Wickelgren, Bundled Discounts, Leverage Theory, and Downstream Competition, 9 Am. L. \& Econ. Rev. 370 (2007); Michael D. Whinston, Exclusivity and Tying in U.S. v. Microsoft: What We Know, and Don't Know, J. Econ. PersP., Spring 2001, at 63; Michael D. Whinston, Tying, Foreclosure, and Exclusion, 80 Am. Econ. Rev. 837 (1990). See generally Eliana Garcés, An Introduction to Tying, Foreclosure, and Exclusion by M.D. Whinston, 8 Competition Pol'y InT'L 145 (2012) (literature survey). Other explanations for tying include price discrimination, which could either harm or promote competition, and an effort to achieve efficiencies such as scale or scope economies for sellers or a reduction in transaction costs for buyers. See, e.g., Marius Schwartz \& Daniel Vincent, Quantity Forcing and Exclusion: Bundled Discounts and Nonlinear Pricing, in 2 Issues in Competition Law and Policy, supra note 52, at 939; David S. Evans \& Michael Salinger, Why Do Firms Bundle and Tie? Evidence from Competitive Markets and Implications for Tying Law, 22 Yale J. on Reg. 37 (2005).

${ }^{66}$ Cascade Health Solutions v. PeaceHealth, 515 F.3d 883 (9th Cir. 2008).

${ }^{67}$ See Farrell et al., supra note 57, at 267 (discussing FTC complaint resolved by consent settlement based on this theory). Market share discounts could exclude rivals through two economic mechanisms. First, they may operate like a tax on incremental buyer purchases from competitors. See id. Second, if rivals' marginal costs increase as their output falls, market share discounts (like quantity discounts) could shift sales away from rivals, thereby raising rivals' costs by denying them economies of scale. See id.

${ }^{68}$ E.g., Nw. Wholesale Stationers, Inc. v. Pac. Stationery \& Printing Co., 472 U.S. 284 (1985) (discussing office supply store members of a purchasing cooperative that expelled a rival).

${ }^{69}$ See generally Hemphill \& Wu, supra note 53.

${ }^{70}$ See United States v. Singer Mfg. Co., 374 U.S. 174 (1963). The pooling of patents that would be essential (or otherwise substitutes) if valid could harm competition through exclusion by reducing the likelihood that questionable patents would be reviewed for validity. Pooling could also benefit competition if used to avoid costly litigation over patent boundaries.

${ }^{71}$ Alcoa, the early 20th century aluminum monopolist, entered into contracts with hydroelectric power producers that barred the power companies from supplying electricity to other aluminum manufacturers. See United States v. Aluminum Co. of Am., 148 F.2d 416, 422 (2d Cir. 1945) (Alcoa) (describing 1912 government enforcement action); see also United States v. Dentsply Int'l., Inc., 399 F.3d 181 (3d Cir. 2005); United States v. Microsoft Corp., 253 F.3d 34 (D.C. Cir. 2001) (exclusionary agreements between Microsoft and Original Equipment Manufacturers and Internet Access Providers). When the excluded firm is forced to adopt a higher cost method of distribution, this exclusionary approach is sometimes described as disrupting an optimal distribution strategy. 
price; this may be worth it if the higher input price forces rivals to exit, ${ }^{72}$ or if the strategy raises competitors' marginal costs, and thus increases the market price by more than the dominant firm's own average costs rise. ${ }^{73}$ The dominant firm may also exclude rivals by contracting with suppliers to give the monopolist the benefit of any discount the suppliers offer a rival. ${ }^{74}$

\section{Commitment to Tough Competition}

In the third category of exclusionary strategies, excluding firms, perhaps especially dominant firms, scare off competition through commitments that convince rivals that aggressive conduct will be met with a strong response. Such a strategy works when the rivals conclude that their best response is to live and let live-to avoid entry, price cutting, or other competitive moves that would provoke the giant. ${ }^{75}$ The leading antitrust example involves predatory pricing: a multimarket monopolist may respond aggressively to single market entry, and profit from doing so mainly by discouraging entry in other markets, allowing the monopolist to protect its market power there. ${ }^{76}$ In addi-

72 See, e.g., Weyerhauser Co. v. Ross-Simmons Hardwood Lumber Co., 549 U.S. 312 (2007) (dominant seller of hardwood lumber allegedly protected the market power of its hardwood lumber mills by bidding up the price of logs, in order to force a rival mill to exit). Overbuying could alternatively be viewed as a constraint on rival conduct, and placed in the first category.

${ }^{73}$ In general, a firm's marginal cost is the cost concept relevant to determining its price, while its average cost is the cost concept relevant to determining its profitability.

${ }^{74}$ See, e.g., Complaint at 3-6, United States v. Blue Cross Blue Shield of Mich., 2012 WL 4513600 (E.D. Mich. Oct. 1, 2012) (No. 10-CV-14155), available at http://www.justice.gov/atr/ cases/f263200/263235.htm; United States v. Delta Dental of R.I., 943 F. Supp. 172, 174-75 (D.R.I. 1996). These contractual provisions are termed "most favored nations" or "most favored customer" clauses. They can protect the dominant firm from new competition by making it impossible for an entrant to obtain key inputs cheaply from suppliers that might have been willing to give the entrant a discount in exchange for a large share of the entrant's business. Most favored customer provisions can also harm competition by facilitating coordination. See generally Jonathan B. Baker, Vertical Restraints with Horizontal Consequences: Competitive Effects of "Most-Favored-Customer" Clauses, 64 Antitrust L.J. 517 (1996).

${ }^{75}$ See generally Richard J. Gilbert, Mobility Barriers and the Value of Incumbency, in 1 HANDBOOK OF Industrial ORganization 475, 476-530 (Richard Schmalensee \& Robert Willig eds., 1989) (excluding firms can make investments that commit them to an aggressive response to future rivalry, with the consequence that future competition is deterred); Steven C. Salop, Strategic Entry Deterrence, 69 Am. Econ. Rev. Papers \& Proceedings 335 (1979) (same); see also John Sutton, Sunk Costs and Market Structure (1981) (excluding firms may be able to deter entry by raising a new firm's post-entry marginal costs of production and distribution, as through investments that have the effect of increasing the sunk investments a new firm must make on marketing or research and development if it chooses to enter).

${ }^{76}$ Spirit Airlines, Inc. v. Nw. Airlines, Inc., 431 F.3d 917, 921-24 (6th Cir. 2005). A predator may also succeed by convincing lenders or investors no longer to support the prey ("deep pocket" predation), by convincing a prospective entrant that the predator's costs are too low to make entry profitable (predation by "cost-signaling"), or by convincing a prospective entrant that its product will be unattractive to buyers ("test-market" predation). See generally Patrick Bolton, Joseph F. Brodley \& Michael H. Riordan, Predatory Pricing: Strategic Theory and Legal Policy, 88 Geo. L.J. 2239 (2000); Aaron S. Edlin, Stopping Above-Cost Predatory Pricing, 111 Yale L.J. 941 (2002). Predatory pricing may also succeed by denying the prey economies of scale 
tion, a dominant firm's contract with suppliers to give the monopolist the benefit of discounts offered to rivals could be viewed as a commitment by the monopolist to match any price reduction by a rival (as well as falling into the previous category, purchase of an exclusionary right).

\section{B. Parallel Legal Rules}

The breadth of practices considered exclusionary in the case law suggests that the courts take exclusion seriously. The parallel structure of the legal rules governing exclusion and collusion similarly suggests that exclusionary conduct is not assigned a lower priority in antitrust law, regardless of differences in the relative frequency with which the two types of conduct are challenged. As will be seen, both types of allegations are generally reviewed under the rule of reason, and in the emerging framework for doing so, courts employ analogous methods of truncation based importantly on the absence of a plausible efficiency justification. ${ }^{77}$ The parallelism in legal rules is not primarily a legacy of antitrust's historical reliance on doctrinal categories that encompass both exclusionary and collusive conduct. ${ }^{78}$ Instead, the truncation

when the prey has fewer captive buyers, Chiara Fumagalli \& Massimo Motta, A Simple Theory of Predation 1-10 (IGIER Working Paper No. 437, 2012), available at http://www.igier.uni bocconi.it/files/437.pdf, or by denying the prey demand side scale economies on the other side of a two-sided platform, Massimo Motta \& Helder Vasconcelos, Exclusionary Pricing in a TwoSided Market (Centre for Econ. Pol'y Research, Discussion Paper No. 9164, 2012). Recent economic studies provide multiple examples of predatory pricing. See, e.g., Kenneth G. Elzinga \& David E. Mills, Predatory Pricing in the Airline Industry: Spirit Airlines v. Northwest Airlines (2005), in The Antitrust Revolution 219 (John E. Kwoka, Jr. \& Lawrence J. White eds., 5th ed. 2009); Malcolm R. Burns, Predatory Pricing and the Acquisition Cost of Competitors, $94 \mathrm{~J}$. Pol. Econ. 266 (1986); David Genesove \& Wallace P. Mullin, Predation and Its Rate of Return: The Sugar Industry, 1887-1914, 37 RAND J. Econ. 47 (2006); Fiona Scott Morton, Entry and Predation: British Shipping Cartels 1879-1929, 6 J. Econ. \& Mgmt. Strategy 679, 714 (1997); David F. Weiman \& Richard C. Levin, Preying for Monopoly? The Case of Southern Bell Telephone Company, 1894-1912, 102 J. Pol. ECon. 103 (1994).

77 The terms "truncated" or "structured" refer to a collection of analytical approaches-per se rules, quick look rules, presumptions, and burden shifting - that potentially condition liability on a limited factual inquiry rather than requiring courts to engage in a wide-open reasonableness analysis. Limiting the factual inquiry is advantageous if it reduces the costs of operating the legal system and provides guidance to firms seeking to comply with the antitrust laws and to generalist judges seeking to enforce those laws-under circumstances in which limiting the evidence considered is unlikely to result in erroneous decisions relative to what a fact-finder would conclude from a complete factual review. See Antitrust Law in Perspective, supra note 25, at 206; id. at 103-06 (discussing benefits and costs of per se condemnation). But see Abraham L. Wickelgren, Determining the Optimal Antitrust Standard: How to Think About Per Se Versus Rule of Reason, 85 S. CAL. L. Rev. Postscript 52, 54 (2012) (noting that, in some settings, more evidence may not improve judicial accuracy, and improved accuracy may not improve firm behavior). In general, the errors from truncation could go in either direction: truncated rules could sweep in conduct that should not be condemned, or avoid condemning conduct that should be prohibited. Conduct that avoids condemnation on a quick look can still be reviewed under the comprehensive rule of reason.

${ }^{78}$ Antitrust's traditional legal categories do not divide perfectly along exclusion vs. collusion lines. See supra Part I. While exclusion cases tend to be framed as vertical agreements or merg- 
methods reflect a modern evolution in rule of reason review that applies to both collusion and exclusion, and shows that courts do not place a higher burden on plaintiffs seeking to demonstrate anticompetitive exclusionary conduct.

In both the exclusion and the collusion context, the legal rules single out for particular attention anticompetitive conduct lacking a plausible efficiency justification. The term "naked" is often applied to collusive agreements among rivals to fix prices, divide markets, or otherwise harm competition that cannot plausibly be justified as efficient. ${ }^{79}$ The term "plain exclusion" will be used to describe the comparable exclusionary conduct: anticompetitive exclusion lacking a plausible efficiency justification. ${ }^{80}$ "Cheap exclusion" is a type of plain exclusion, namely plain exclusion that is also inexpensive for the excluding firms to implement. ${ }^{81}$

It is commonplace today that agreements among rivals (which more commonly threaten collusive rather than exclusionary harms), when reviewed under Sherman Act Section 1, are analyzed under the rule of reason through

ers, or as monopolization or attempts to monopolize, those categories can also be employed to attack collusive conduct, and the legal categories in which collusive cases tend to be framed, including horizontal agreements, can also be employed to attack exclusionary conduct. Within a doctrinal category, moreover, the legal rule generally does not differ depending on whether the alleged conduct is collusive or exclusionary. The rules governing group boycotts may be an exception, however. The Supreme Court's collusive group boycott decision in FTC v. Superior Court Trial Lawyers Association (SCTLA) treated that conduct as tantamount to price fixing among rivals. 493 U.S. 411, 423 (1990). The SCTLA majority did not make reference to the Court's then-recent exclusionary group boycott decision, Northwest Wholesale Stationers, Inc. $v$. Pacific Stationery and Printing Co., 472 U.S. 284 (1985). Stationers appears to demand a more extensive showing (perhaps including proof of market power) before applying a per se rule to invalidate the conduct than is required for horizontal price fixing-though it is not possible to say more than "appears" and "perhaps" because Stationers does not clearly delineate the elements of the per se rule it applies. In the wake of Stationers, the lower courts have grappled inconclusively with the issue. See 1 Antitrust Law Developments, supra note 36, at 492-93.

${ }^{79}$ See, e.g., White Motor Co. v. United States, 372 U.S. 253, 263 (1963) ("Horizontal territorial limitations . . . are naked restraints of trade with no purpose except stifling of competition.").

${ }^{80}$ The seemingly analogous term "naked exclusion" was not adopted because that phrase is used in the economics literature to describe a particular economic model. See Eric B. Rasmusen, J. Mark Ramseyer \& John S. Wiley, Jr., Naked Exclusion, 81 Am. Econ. Rev. 1137 (1991). But see Jonathan M. Jacobson, Exclusive Dealing, "Foreclosure," and Consumer Harm, 70 ANTITRUST L.J. 311, 360 (2002) (referring to "naked" exclusion); Krattenmaker \& Salop, supra note 9, at 227 (same). Plain exclusion in a Sherman Act Section 2 setting has been referred to as "no efficiency justification" monopolization. Harry First, The Case for Antitrust Civil Penalties, 76 Antitrust L.J. 127, 160 (2009).

${ }^{81}$ Susan A. Creighton, D. Bruce Hoffman, Thomas G. Krattenmaker \& Ernest A. Nagata, Cheap Exclusion, 72 AnTitrust L.J. 975, 977 (2005); Patricia Schultheiss \& William E. Cohen, Cheap Exclusion: Role and Limits (Jan. 14, 2009) (unpublished manuscript), available at http:// www.ftc.gov/os/sectiontwohearings/docs/section2cheapexclusion.pdf. The concept of cheap exclusion was developed in part as a guide to the enforcement agencies in allocating investigative resources, and incorporated the expense of implementation on the view that it would be related to the likelihood of uncovering anticompetitive exclusion. 
an analysis that can be structured or truncated using quick look or burdenshifting approaches. ${ }^{82}$ In consequence, a horizontal restraint can be condemned without a comprehensive analysis of its effects on competition if three elements are demonstrated: (a) an agreement among rivals, ${ }^{83}$ (b) certain facts suggesting the likelihood of harm to competition; and (c) the absence of a plausible efficiency justification for the agreement at issue. The second element may be satisfied by showing that the conduct falls in a traditional per se category (price fixing or market division), ${ }^{84}$ by showing that anticompetitive effect is intuitively obvious based on facial analysis of the agreement, ${ }^{85}$ or (with retrospective conduct) through actual effects evidence demonstrating that competition has been harmed. ${ }^{86}$

${ }^{82}$ See Andrew I. Gavil, Moving Beyond Caricature and Characterization: The Modern Rule of Reason in Practice, 85 S. CAL. L. Rev. 733, 744-53 (2012); see also ANTITRUst LAW IN PersPeCtIVE, supra note 25, at 206 (plaintiffs seek courts to truncate the rule of reason review of horizontal restraints in order "to condemn conduct without detailed analysis of market power and likely effects" when the conduct "is facially objectionable or has actual adverse effects," and to do so when the conduct "would be in a traditional per se category but for plausible efficiencies, and on review the efficiencies do not actually appear substantial"). Courts may also consider truncating the rule of reason review of horizontal restraints in order to exculpate conduct when defendants collectively have a low market share. Id. In the context of burden shifting, however, the latter possibility would presumably be considered only after both plaintiff and defendant have satisfied their initial burdens of production.

${ }^{83}$ Application of Sherman Act Section 1 is predicated on proof of agreement; the rules discussed in this paragraph govern the analysis of agreements among (horizontal) competitors. See Sherman Act, 15 U.S.C. $§ 1$. The agreement element often goes undisputed, but if an agreement among rivals must be inferred from circumstantial evidence, that element may be difficult to assess. See generally Baker, supra note 25; Louis Kaplow, Direct vs. Communications-Based Prohibitions on Price-Fixing, 3 J. Legal Analysis 449 (2011). Antitrust law could in theory condemn collusive conduct on a truncated basis without proof of agreement among rivals if the other elements of the truncated rule are present, but the limited experience with identifying collusive effects from unilateral conduct after Ethyl and from vertical agreements after GTE Sylvania and Leegin offers little guidance as to whether and when courts would do so. See generally Leegin Creative Leather Prods., Inc. v. PSKS, Inc., 551 U.S. 877 (2007) (resale price maintenance); Cont'l T.V., Inc. v. GTE Sylvania Inc., 433 U.S. 36 (1977) (non-price restraints); E.I. du Pont de Nemours \& Co. v. FTC, 729 F.2d 128 (2d Cir. 1984) (Ethyl).

${ }^{84}$ See, e.g., Palmer v. BRG of Ga., Inc., 498 U.S. 46 (1990) (horizontal market division); United States v. Trenton Potteries Co., 273 U.S. 392 (1927) (horizontal price fixing). The Supreme Court has also recognized that a collusive group boycott is tantamount to horizontal price fixing. FTC v. Superior Ct. Trial Lawyers Ass'n, 493 U.S. 411, 436 n.19 (1990).

${ }^{85}$ See, e.g., PolyGram Holding, Inc. v. FTC, 416 F.3d 29, 36 (D.C. Cir. 2005) ("If, based upon economic learning and the experience of the market, it is obvious that a restraint of trade likely impairs competition, then the restraint is presumed unlawful ...."). The court went on to find this criterion satisfied by an agreement between joint venturers to restrain price cutting and advertising with respect to products not part of the joint venture. $I d$.

${ }^{86}$ E.g., FTC v. Ind. Fed'n of Dentists, 476 U.S. 447 (1986); NCAA v. Bd. of Regents of the Univ. of Okla., 468 U.S 85 (1984). But see Republic Tobacco Co. v. N. Atl. Trading Co., 381 F. 3d 717, 737 (7th Cir. 2004) (noting that even though Indiana Federation of Dentists does not allow a plaintiff to dispense entirely with market definition by proffering actual effects evidence, a plaintiff must still show the "rough contours" of a market and that defendant commands a substantial share). In a retrospective exclusion case, for example, proof that prices rose after a rival was excluded might count as actual effects evidence. (The probative value of actual effects 
This approach is typically implemented today through a burden-shifting framework that has been developed by the lower courts in agreement cases alleging collusive effects. ${ }^{87} \mathrm{~A}$ plaintiff must satisfy an initial burden of production by demonstrating that competition has been or likely will be harmed ${ }^{88}$ If the plaintiff makes a satisfactory initial showing, the burden of production shifts to defendants to identify a plausible business justification. If defendant does so, the plaintiff, on whom the burden of persuasion rests, must prove unreasonableness by showing that the harm to competition is not dissipated or eliminated by the benefit to competition, ${ }^{89}$ or that defendant had a practical less-restrictive alternative for achieving the benefits with less harm to competition. ${ }^{90}$

The burden-shifting framework implies that the rule of reason review of allegedly collusive horizontal agreements can be truncated relative to the way a court would proceed under the comprehensive rule of reason in two senses. ${ }^{91}$

evidence can be contested-in this example, perhaps, with evidence that non-excluded firms experienced an independent increase in marginal cost of sufficient magnitude to explain the price increase.)

87 See, e.g., PolyGram Holding, 416 F.3d at 36 (D.C. Cir. 2005); Law v. NCAA, 134 F.3d 1010, 1019 (10th Cir. 1998); see also Andrew I. Gavil, Burden of Proof in U.S. Antitrust Law, in 1 Issues in Competition LAw AND Policy, supra note 52, at 125, 145-48; Gavil, supra note 82, at 758-60 (discussing burden shifting and the rule of reason).

88 The plaintiff may meet this burden with any of the limited factual showings of harm to competition that would provide a basis for truncated or quick look condemnation: that the agreement falls in a traditional per se category, that harm is intuitively obvious, or that harm has already occurred (actual effects evidence). Because the plaintiff also has the option of proving unreasonableness through a comprehensive rule of reason review, the plaintiff can also satisfy its initial burden with a more detailed demonstration of harm to competition based on an analysis of a wider range factors such as defendant market power or the actual effects of the agreement as implemented -in which case the plaintiff's initial burden of production would merge with its ultimate burden of persuasion. In practical application under Sherman Act Section 1, most plaintiffs have failed to satisfy their initial burden. See Michael A. Carrier, The Real Rule of Reason: Bridging the Disconnect, 1999 BYU L. REV. 1265, 1293 [hereinafter Bridging the Disconnect]; Michael A. Carrier, The Rule of Reason: An Empirical Update for the 21st Century, 16 GEO. Mason L. Rev. 827, 831-32 (2009) [hereinafter Empirical Update].

${ }^{89}$ Courts routinely describe the unstructured reasonableness inquiry in terms of balancing benefits and harms, but in practice they almost never actually balance. See Carrier, Bridging the Disconnect, supra note 88, at 1293; Carrier, Empirical Update, supra note 88, at 831-32. Accordingly, following a suggestion of Prof. Andrew Gavil, in this article I describe reasonableness review as evaluating whether the benefits "dissipate or eliminate" the harms rather than as "balancing" or "weighing" harms against benefits. If a court were to permit efficiency benefits in one market to justify conduct that harmed competition in a different market, however, it would be difficult to interpret that process other than as balancing.

${ }^{90}$ For one court's statement of this framework, see Law v. NCAA, 134 F.3d at 1019; and see also Gregory v. Fort Bridger Rendezvous Association, 448 F.3d 1195, 1205 (10th Cir. 2006) (reaffirming Law framework). For a collection of cases, see 1 AnTITRUST LAw DeVELOPMENTS, supra note 36 , at 62 n.353.

91 This article uses the phrases "comprehensive rule of reason," "unstructured rule of reason," and "full blown rule of reason" interchangeably to refer to the type of wide-ranging analysis undertaken in Board of Trade. See generally Bd. of Trade of City of Chicago v. United States, 246 U.S. 231 (1918). 
First, a plaintiff may satisfy its initial burden without undertaking a detailed market analysis (which would require defining markets, analyzing market shares, evaluating entry conditions, and the like) by relying instead upon categorization of the agreement, facial analysis of the agreement, or actual effects evidence. In addition, harm to competition may be inferred from the limited showing required to satisfy the plaintiff's initial burden combined with the absence of plausible efficiencies, without need for further analysis.

The courts appear to be developing a structured approach for evaluating anticompetitive exclusion that is similar to the approach they apply to evaluate anticompetitive collusion. As with alleged collusive harms, allegations of anticompetitive exclusion are generally tested under the rule of reason across doctrinal categories. ${ }^{92}$ Exclusive dealing allegations are evaluated for their reasonableness, whether challenged under the Sherman Act or the Clayton Act. ${ }^{93}$ Vertical agreements, which could result in exclusion, are reviewed under the rule of reason regardless of whether they involve price or non-price terms. ${ }^{94}$ Tying and exclusionary group boycotts are evaluated under the rule of reason if a per se rule does not apply. ${ }^{95}$ The exclusionary conduct element of the monopolization offense is reviewed in a burden-shifting framework similar to the approach now applied to evaluate the reasonableness of conduct under Sherman Act Section $1 .{ }^{96}$

\footnotetext{
${ }^{92}$ Many economic factors relevant to showing that exclusion and collusion have harmed competition, discussed below in Parts III and IV, would be relevant when applying the unstructured rule of reason, but they would not all be relevant if the reasonableness review is truncated.

${ }^{93}$ Jefferson Parish Hosp. Dist. No. 2 v. Hyde, 466 U.S. 2, 44-45 (1984) (O’Connor, J, concurring) (Sherman Act); Omega Envtl., Inc. v. Gilbarco, Inc., 127 F.3d 1157, 1162 (9th Cir. 1997) (Clayton Act); U.S. Healthcare, Inc. v. Healthsource, Inc., 986 F.2d 589, 593 (1st Cir. 1993) (Sherman Act); see Jacobson, supra note 80, at 363 (noting that exclusive dealing analysis has been "freed . . . to conform to more general analysis of trade restraints under the rule of reason").

${ }^{94}$ Leegin Creative Leather Prods., Inc. v. PSKS, Inc., 551 U.S. 877 (2007) (resale price maintenance); Cont'l T.V., Inc. v. GTE Sylvania Inc., 433 U.S. 36 (1977) (non-price restraints).

${ }_{95}$ Jefferson Parish, 466 U.S. at 29 (tying); United States v. Microsoft Corp., 253 F.3d 34, 84 (D.C. Cir. 2001) (tying); see Nw. Wholesale Stationers, Inc. v. Pac. Stationery \& Printing Co., 472 U.S. 284, 297 (1985) (exclusionary group boycott); United States v. Visa U.S.A., Inc., 344 F.3d 229 (2d Cir. 2003) (analyzing conduct tantamount to an exclusionary group boycott under the rule of reason).

${ }^{96}$ Compare Microsoft, 253 F.3d at 58-59, with PolyGram Holding, Inc. v. FTC, 416 F.3d 29 (D.C. Cir. 2005), and Law v. NCAA, 134 F.3d 1010 (10th Cir. 1998). Cf. United States v. Standard Oil Co., 221 U.S. 1, 61-62 (1911) (noting that the rule of reason applies to the analysis of conduct under both Sherman Act Section 1 and Sherman Act Section 2). The reasonableness analysis of monopolization is structured further when price-cutting is the alleged exclusionary act, as predatory pricing requires proof of below-cost pricing and an assessment of the pricecutter's prospects for recouping the costs of below-cost pricing through the later exercise of monopoly power. See Brooke Grp. Ltd. v. Brown \& Williamson Tobacco Corp., 509 U.S. 209 (1993) (applying Sherman Act principles to Robinson-Patman Act decision). The recoupment inquiry can be understood as assessing the profitability of the alleged anticompetitive strategy, and thus evaluating whether the excluding firms can solve the third "exclusion problem" discussed below in Part IV.
} 
The courts have also arguably begun to develop an approach for truncating the rule of reason review of exclusionary conduct across legal categories, much as they have come to do with collusive horizontal agreements. Synthesizing the leading cases, exclusionary conduct may be found unreasonable today without a comprehensive analysis of the nature, history, purpose, and actual or probable effect of the practice in the presence of two additional elements: (i) if the excluding firms have foreclosed competition from all actual or potential rivals other than insignificant competitors, ${ }^{97}$ and (ii) if the exclusionary conduct lacks a plausible efficiency justification. ${ }^{98}$ The need to identify the excluding firms' rivals may call for at least an informal market definition, ${ }^{99}$ but this predicate would not undermine the benefits of truncation in reducing transaction costs and providing guidance when market definition is not difficult, ${ }^{100}$ and may not fully undermine those benefits even if market

${ }^{97}$ Aspen Skiing v. Aspen Highlands Skiing Corp., 472 U.S. 585 (1985) (discussing a dominant firm that excluded its only competitor); Microsoft, 253 F.3d at 55 (noting that exclusionary conduct protected the "applications barrier to entry" that insulated the dominant firm from competition from current and potential rivals); United States v. Dentsply Int'l., Inc., 399 F.3d 181 (3d Cir. 2005) (discussing a dominant firm that foreclosed its rivals from access to dealers, and noting that while this exclusionary method did not cover two small rivals that sold directly to the ultimate customers, their alternative method of distribution was less effective). In Lorain Journal Co. v. United States, 342 U.S. 143 (1951), the dominant daily newspaper excluded a rival radio station from the advertising market but did not exclude another competitor, a weekly newspaper. The Supreme Court and the district court appear to have treated the small weekly newspaper as an insignificant market participant, in which case the exclusionary conduct foreclosed only the sole significant rival, but these decisions could instead be read to have defined the market narrowly to exclude that firm as a participant. United States v. Lorain Journal Co., 92 F. Supp. 794, 796-97 (N.D. Ohio 1950), aff'd, 342 U.S. 143 (1951).

${ }^{98}$ See United States v. Visa U.S.A., Inc., 344 F.3d 229 (2d Cir. 2003) (government prevailed by showing harm to competition and the absence of procompetitive benefits, though the inquiry into competitive harm was wide-ranging); Gavil, supra note 14, at 27-28 (noting that plaintiffs are most likely to succeed in proving exclusionary violations under Sherman Act Section 2 when the harm to competition or defendant's market power are obvious and the defendant lacks a plausible business justification); see also Mark S. Popofsky, Defining Exclusionary Conduct: Section 2, the Rule of Reason, and the Unifying Principle Underlying Antitrust Rules, 73 ANTITRUST L.J. 435, 445 (2006) (the Microsoft framework for evaluating exclusionary conduct under Sherman Act Section 2 "is virtually indistinguishable from the test courts employ under Section 1 's rule of reason").

${ }^{99}$ See Republic Tobacco Co. v. N. Atlantic Trading Co., 381 F. 3d 717, 737 (7th Cir. 2004) (noting that the approximate magnitude of market shares may be assessed after proving the "rough contours" of a market). By contrast, the second element in the truncated reasonableness review of collusive conduct does not require market definition. If truncated condemnation of exclusionary conduct is instead based on actual evidence of anticompetitive effect - an open possibility, see infra notes 129-31 and accompanying text-market definition would presumably not be required.

100 Market definition appears to have been uncontroversial in a number of pro-plaintiff exclusion decisions. See, e.g., Lorain Journal, 342 U.S. 143 (mass dissemination of news and advertising, both of a local and national character, in Lorain, Ohio); Dentsply, 399 F.3d 181 (sale of prefabricated artificial teeth in the United States); Conwood Co. v. U.S. Tobacco Co., 290 F.3d 768 (6th Cir. 2002) (moist snuff in the United States). 
definition is strongly contested. ${ }^{101}$ Moreover, it may not be necessary to identify with specificity every significant foreclosed rival to determine that all such rivals were excluded. ${ }^{102}$

The D.C. Circuit's analysis of monopolization in its en banc Microsoft decision provides the most detailed articulation of this approach. ${ }^{103}$ The monopolization offense has two doctrinal elements: monopoly power and exclusionary conduct (acquiring or maintaining that power through anticompetitive means). ${ }^{104}$ To identify the second element, exclusionary conduct, the circuit court adopted a burden-shifting framework consistent with "a century of case law on monopolization[.]" 105 Under its scheme, plaintiff initially establishes a prima facie case by demonstrating anticompetitive effect. ${ }^{106}$ If plaintiff successfully does so, the defendant may proffer a non-pretextual procompetitive justification for its conduct, which shifts the burden back to the plaintiff to rebut that claim. ${ }^{107}$ If the justification stands unrebutted, the plaintiff must demonstrate that the anticompetitive harm of the conduct outweighs the procompetitive benefit. ${ }^{108}$ In applying this framework, proof that the monopolist has foreclosed all actual or potential rivals would undoubtedly be sufficient to establish plaintiff's prima facie case, ${ }^{109}$ after which defendant's inability to identify a plausible efficiency justification would suffice to prove that the conduct is exclusionary and thus to condemn it as a violation of Sherman Act Section 2.

Truncated condemnation on a similar basis appears possible across most if not all of the disparate legal categories in which exclusionary conduct allegations may be evaluated, including attempt to monopolize, ${ }^{110}$ monopoliza-

${ }^{101}$ Problems that arise in defining markets in exclusion settings are discussed in Jonathan B. Baker, Market Definition: An Analytical Overview, 74 AnTitrust L.J. 129, 166-73 (2007).

102 Applications of Comcast Corporation, General Electric Company, and NBC Universal, Inc., for Consent to Assign Licenses and Transfer Control of Licensees, Memorandum Opinion and Order, 26 FCC Rcd. 48 (2011), available at transition.fcc.gov/FCC-11-4.pdf; see also United States v. Microsoft Corp., 253 F.3d 34, 79-80 (D.C. Cir. 2001) (inferring causal link between defendant's anticompetitive conduct and maintenance of its monopoly from the exclusion of nascent competitive threats, but not identifying each excluded potential rival).

${ }^{103}$ See Microsoft, 253 F.3d at 78-80.

104 United States v. Grinnell Corp., 384 U.S. 563, 570-71 (1966). Microsoft describes the second element as "exclusionary conduct." Microsoft, 253 F.3d at 58.

105 Microsoft, 253 F.3d at 58.

106 Id. at $58-59$.

${ }^{107} I d$. at 59 .

${ }_{108} I d$.

${ }^{109}$ Market definition may be the predicate for identifying rivals. See supra notes 99-102 and accompanying text. In Microsoft, the court identified a market in the context of evaluating the monopoly power element of the monopolization offense. See Microsoft, 253 F.3d at 50-56.

${ }^{110}$ See Lorain Journal Co. v. United States, 342 U.S. 143 (1951) (dominant daily newspaper excluded rival radio station from advertising market). Neither the Supreme Court nor the district court made clear whether advertising competition from a small weekly newspaper in the same 
tion, ${ }^{111}$ exclusionary group boycott, ${ }^{112}$ non-price vertical restraints, ${ }^{113}$ and exclusive dealing. ${ }^{114}$ The case law establishing the truncated approach to reasonableness review of exclusionary conduct does so more clearly for monopolization, the legal category addressed by Microsoft's burden-shifting framework, than for violations that would fall in other legal categories. For this reason, the cases could be read as establishing a burden-shifting approach to truncation only for the review of monopolization allegations. That narrow reading would be inconsistent with the broad trend in antitrust elevating concepts over categories discussed above in Part I. ${ }^{115}$ Hence, modern courts would likely look across doctrinal pigeonholes for guidance in evaluating exclusionary conduct claims, and adopt a common framework for doing so.

The specifics of the structured approach are less evident in the exclusion context than the collusive one because many more collusion cases have been condemned after truncated review than exclusion cases. ${ }^{116}$ It is nevertheless

city was ruled out by defining the market to exclude that firm as a participant-in which case the exclusionary conduct at issue foreclosed competition from all rivals-or whether it treated that firm as an insignificant market participant, in which case the exclusionary conduct foreclosed only the sole significant rival. United States v. Lorain Journal Co., 92 F. Supp. 794, 796-97 (N. D. Ohio 1950), aff'd, 342 U.S. 143 (1951).

${ }_{111}$ Aspen Skiing v. Aspen Highlands Skiing Corp., 472 U.S. 585 (1985); Microsoft, 253 F.3d at 64-78. Cf. Jonathan B. Baker, Promoting Innovation Competition Though the Aspen/Kodak Rule, 7 Geo. Mason L. Rev. 495, 496 (1999) (explaining that the Supreme Court had established a truncated legal rule finding a violation of Sherman Act Section 2 when a monopolist excludes rivals by restricting a complementary or collaborative relationship without an adequate business justification).

${ }^{112}$ See Nw. Wholesale Stationers, Inc. v. Pac. Stationery \& Printing Co., 472 U.S. 284, 298 (1985) (remanding for review under a legal rule creating the possibility of truncated condemnation). The Stationers Court used the term "per se rule," but, in contrast to the traditional per se rules employed in the analysis of horizontal restraints, conditioned application of its rule on up to three elements including defendant market power. See supra note 78. For this reason, its approach is better thought of as describing a truncated or structured inquiry. Accord, Toys "R" Us, Inc. v. FTC, 221 F.3d 928, 936 (7th Cir. 2000).

113 See Graphic Prods. Distribs., Inc. v. ITEK Corp., 717 F.2d 1560, 1583 (11th Cir. 1983) (affirming jury verdict for plaintiff upon proof of defendant market power absent evidence that the restraints were reasonably necessary to achieve a legitimate business purpose); Eiberger $\mathrm{v}$. Sony Corp., 622 F.2d 1068 (2d Cir. 1980) (affirming unjustified exclusion condemned without further inquiry into defendant market power); Gavil, supra note 14, at $8 \mathrm{n} .29$ ("[Continental T.V., Inc. v. GTE Sylvania Inc., 433 U.S. 36 (1977),] strongly implies that if a plaintiff can demonstrate that its supplier possesses market power, the burden of production should shift to the defendant to justify its conduct."). Although non-price vertical restraints can be subject to truncated condemnation, rule of reason litigation of such agreements almost always ends with defendant prevailing. See Hovenkamp, supra note 36, § 11.6b; Antitrust Law in Perspective, supra note 25, at 369 (Sidebar 4-1: Dealer Relations After Sylvania).

${ }_{114} C f$. United States v. Dentsply Int'l, Inc., 399 F.3d 181 (3d Cir. 2005) (analyzing exclusive dealing conduct as monopolization).

115 See supra notes $25-27$ and accompanying text.

116 The small number of recent exclusion decisions consistent with the synthesized rule does not mean that there is no such rule; it more likely shows that there are fewer litigated exclusionary conduct claims than collusive conduct claims in the first place, or that the conduct in such cases is less frequently justified with a plausible efficiency claim. The enforcement agencies 
evident from the synthesized rule that as the legal rules governing exclusion and collusion evolve, they are converging on an approach that is more likely to find unlawful conduct lacking a plausible efficiency justification, regardless of whether the anticompetitive effects are exclusionary or collusive-thus demonstrating that antitrust's doctrinal rules evaluate collusion and exclusion in a similar way, and do not tilt the scales to downplay exclusion.

\section{Refining the Truncated Rule Governing Exclusion}

The courts have not explicated as doctrine the synthesized rule for truncating the reasonableness review of exclusionary conduct set forth above. ${ }^{117}$ In consequence, many questions about truncated condemnation of exclusionary conduct remain open for future refinement, including the following six. ${ }^{118}$

First, if some rivals are not excluded, what showing is required to demonstrate their competitive insignificance? As an economic matter, a firm or firms would be insignificant for this purpose if, given the cost and difficulty of output expansion, it or they (collectively) would not increase sales sufficiently to undermine the post-exclusion exercise of market power. Courts that have treated non-excluded firms as insignificant have not experienced difficulty concluding that they have high costs of output expansion or low market shares, ${ }^{119}$ but these factual determinations will not always be easy to make. ${ }^{120}$

more frequently challenge naked collusion than plain exclusion. See infra note 237 and accompanying text (discussing relative frequency of exclusion and collusion cases).

117 An earlier work by the present author described a truncated legal rule established by the Supreme Court in two monopolization decisions: Aspen and Kodak. Aspen Skiing v. Aspen Highlands Skiing Corp., 472 U.S. 585 (1985); Eastman Kodak Co. v. Image Technical Servs., Inc., 504 U.S. 451 (1992); Baker, supra note 111, at 496. Under that rule, Sherman Act Section 2 is violated when a monopolist excludes rivals by restricting a complementary or collaborative relationship without an adequate business justification. This discussion updates that prior analysis to reflect more recent precedent. Most importantly, a number of questions about the elements of the rule that seemed open in 1999, see Baker, supra, at 503-05, have been addressed through the analytical framework set forth in Microsoft, United States v. Microsoft Corp., 253 F.3d 34 (D.C. Cir. 2001) (en banc). The generality of the Microsoft framework also suggests, contrary to the cautious interpretation of the cases offered in 1999, that truncation does not turn on the means of exclusion (that is, it would not be limited to exclusionary conduct that takes the form of a restriction to a prior complementary or collaborative relationship). See id.

${ }_{118}$ In addition, it is an open question whether truncated condemnation under the rule of reason can be applied to exclusionary conduct undertaken by or associated with the creation of joint research or production ventures, including voluntary standards development organizations, as these types of joint ventures "shall be judged on the basis of its reasonableness, taking into account all relevant factors affecting competition ...." 15 U.S.C. $\$ 4302$.

${ }^{119} \mathrm{~A}$ low market share may indicate competitive insignificance in this context because small firms often have difficulty expanding output inexpensively, as would be the case if they are small mainly for reasons other than aggressive competition by the excluding firms. Even if production costs are low and do not increase with output, for example, the costs of identifying and marketing to new customers often increase as output rises.

${ }^{120}$ But see supra note 100 (providing examples from exclusionary conduct cases in which courts did not find market definition difficult). 
If competitive insignificance is not easily determined, the truncated rule could lose its administrability advantage over unstructured rule of reason review, leading a court to prefer not to decide the matter before it on a quick look.

Second, if the excluding firm or firms have market power (most likely demonstrated through market shares) can a court infer that all significant rivals, actual or potential, have been excluded or likely would be excluded from evidence that one such rival has been excluded? That is, if the excluding firms have market power and are able to foreclose one rival, is it reasonable to presume they have the ability and incentive to foreclose all rivals? The Federal Trade Commission answered this question in the affirmative in a decision condemning an exclusionary group boycott. ${ }^{121}$ If its answer is generally accepted, truncated condemnation could be undertaken without identifying every significant rival and proving that each has been excluded or likely would be excluded. ${ }^{122}$ Instead, exclusionary conduct would be condemned without full rule of reason review on a showing that one or more rivals were excluded, the excluding firms possess market power, and the exclusionary conduct at issue had no plausible efficiency justification.

Third, in a prospective exclusion case, if the exclusionary conduct forecloses all actual and potential rivals, and has no business justification, can it be condemned without proof that the excluding firms previously had market power-particularly regardless of the excluding firm's market share? ${ }^{123}$ The obvious logic of the inference created by the synthesized rule set forth

121 Toys "R" Us, Inc., 126 F.T.C. 415, 590-608 (1998), aff'd, 221 F.3d 928 (7th Cir. 2000); see Multistate Legal Studies, Inc. v. Harcourt Brace Jovanovich Legal and Prof'l Publ'ns, Inc., 63 F.3d 1540, 1549, 1555-56 (10th Cir. 1995) (explaining that evidence of defendant market power and entry barriers suggests a triable issue of fact concerning recoupment in a predatory pricing case). Moreover, if harm to competition can be inferred from proof of market power and the absence of efficiencies, it is an open question what market share would be sufficient to satisfy the rule. In Toys, the FTC applied the rule to a firm it found to have a market share of more than 30 percent in the areas in which it did business and between 40 percent and 50 percent in many cities. Toys, 126 F.T.C. at 597-99. The risk of a false positive-here the risk of wrongly inferring that non-excluded rivals would be unable to counteract the harm to competition by collectively expanding output-may be greater the lower the market share threshold.

122 See Christine A. Varney, A Post-Leegin Approach to Resale Price Maintenance Using a Structured Rule of Reason, Antitrust, Fall 2009, at 22, 24-25 (proposing that a plaintiff proceeding on a manufacturer or retailer exclusion theory of harm from resale price maintenance can satisfy its prima facie case, thus shifting a burden to defendant to prove efficiencies, by showing: that defendant has market power, that the resale price maintenance arrangements result in substantial foreclosure, and that exclusionary effects are plausible); $c f$. Nw. Wholesale Stationers, Inc. v. Pac. Stationery \& Printing Co., 472 U.S. 284 (1985) (truncated condemnation rule looks only to exclusion, market power, and the absence of efficiencies).

${ }^{123}$ Market power in exclusion cases can also be demonstrated by actual effects evidence. E.g., Eastman Kodak Co. v. Image Technical Servs., Inc., 504 U.S. 451, 477 (1992) (noting that market power may be inferred from direct evidence that prices rose and rivals were excluded); United States v. Microsoft Corp., 253 F.3d 34, 51, 57 (D.C. Cir. 2001) (holding on alternative grounds of monopoly power); ReMax Int'l, Inc. v. Realty One, Inc., 173 F.3d 995 (6th Cir. 1999); see also Geneva Pharms. Tech. Corp. v. Barr Labs. Inc., 386 F.3d 485, 500 (2d Cir. 2004) 
above-a firm clearly can exercise market power by excluding all its rivals no matter how small its prior share-implies that proof of pre-existing market power should be unnecessary for truncated condemnation. ${ }^{124}$ Moreover, that outcome is consistent with the rule governing attempted monopolization, which requires proof of a "dangerous probability" of achieving monopoly power rather than pre-existing monopoly power, ${ }^{125}$ and the case law establishing that a monopoly obtained through the fraudulent acquisition of a patent violates Sherman Act Section 2. ${ }^{126}$ Given the historical importance of defendant market share in evaluating allegations of anticompetitive exclusion, even outside of Sherman Act Section 2, ${ }^{127}$ however, it is possible that a court could nevertheless require proof of excluding firm market power before truncating its reasonableness review. ${ }^{128}$

Fourth, is truncated condemnation available in a retrospective exclusion case without proof of market power but with a showing of actual anticompetitive effects? This approach would follow the logic of a quick look methodology established in collusive agreement cases, ${ }^{129}$ and was endorsed for

(showing of adverse effects insufficient on the facts of the case); Tops Mkts., Inc. v. Quality Mkts., Inc., 142 F.3d 90, 97 (2d Cir. 1998) (same).

124 "A firm that seeks to create a monopoly by dynamiting its competitor's plants does not need market power-only a saboteur and a match.” See HovenKAMP, supra note 36, § 6.5.

${ }^{125}$ Spectrum Sports, Inc. v. McQuillan, 506 U.S. 447, 455 (1993). Market shares too low to prove market power may be sufficient to show "dangerous probability." 1 AnTITRUST Law DeVELOPMENTS, supra note 36 , at 323.

126 Walker Process Equip. Inc. v. Food Mach. \& Chem. Corp., 382 U.S. 172, 173-74 (1965). To similar effect, suppose a firm manipulates a standard-setting process through deception to ensure that the standard incorporates its intellectual property, giving it the potential to exercise market power by asserting intellectual property rights. This showing combined with proof that the exclusionary conduct has no legitimate business justification would likely be sufficient to prove harm to competition if there is no practical way to compete without complying with the standard. See Rambus Inc. v. FTC, 522 F.2d 456, 467-68 (D.C. Cir. 2008) (finding no antitrust violation because the proof of exclusion was insufficient on the facts of the case); Note, Deception as an Antitrust Violation, 125 HaRv. L. REv. 1235, 1251-54 (2011) (advocating rule permitting court to find monopolization when a monopolist's deceptive act was reasonably capable of contributing to monopoly power, and to find an agreement to deceive unreasonable if it creates a significant anticompetitive effect).

127 See, e.g., 1 Antitrust Law Developments, supra note 36, at 216 ("Since the early 1970s, judicial decisions [in exclusive dealing cases] have established a virtual safe harbor for market foreclosure of 20 percent or less.").

${ }^{128}$ See Jacobson, supra note 80, at 365 (noting that in the reasonableness analysis of exclusive dealing within a burden-shifting framework allowing for truncated condemnation, a plaintiff must prove defendant market power to satisfy its initial burden).

${ }^{129}$ FTC v. Ind. Fed'n of Dentists, 476 U.S. 447 (1986); NCAA v. Bd. of Regents of the Univ. of Okla., 468 U.S 85 (1984). 
anticompetitive exclusion by the Federal Trade Commission, ${ }^{130}$ but has been questioned by the Seventh Circuit. ${ }^{131}$

Fifth, how will the synthesized rule for truncating the reasonableness review of exclusionary conduct be harmonized with the rules establishing below-cost pricing and recoupment as elements of the predatory pricing offense? ${ }^{132}$ Truncated condemnation is unlikely to be available in such cases because one or more of the many competitive justifications for low prices would typically appear plausible, ${ }^{133}$ rather than because these elements are part of the offense. (On similar reasoning. truncated condemnation is also unlikely to be available when the exclusionary conduct involves the introduction of a (non-sham) product design improvement.) ${ }^{134}$

Sixth, what business justifications for exclusionary conduct are cognizable? ${ }^{135}$ For example, can defendants justify exclusionary conduct on the ground that the opportunity to charge monopoly prices induces the excluding firms to invest in developing or marketing innovative products or production processes? ? $^{136}$ This argument would seem to be "a defense based on the as-

${ }^{130}$ See, e.g., Toys "R" Us, Inc., 126 F.T.C. 415, 608 (1998), aff'd, 221 F.3d 928 (7th Cir. 2000).

${ }^{131}$ In Republic Tobacco Co. v. North Atlantic Trading Co., 381 F. 3d 717, 737-38 (7th Cir. 2004), the Seventh Circuit declined to allow the plaintiff to dispense with market definition by proffering actual effects evidence in a vertical exclusion case. Although this position had seemingly been rejected by the Supreme Court when previously adopted by the same circuit court, see Indiana Federation of Dentists, 476 U.S. at 465-66, rev'g 745 F.2d 1124 (7th Cir. 1984), the appellate court in Republic Tobacco interpreted Indiana Federation of Dentists to require plaintiff to show the "rough contours" of a market and that the defendant commands a substantial share, Republic Tobacco, 381 F.3d at 737. That Seventh Circuit took a different view of Indiana Federation of Dentists in an earlier exclusionary group boycott case not discussed in Republic Tobacco. See Wilk v. AMA, 895 F.2d 352, 360 (7th Cir. 1990) (alternative holding).

${ }_{132}$ Brooke Grp. Ltd. v. Brown \& Williamson Tobacco Corp., 509 U.S. 209 (1993).

${ }^{133}$ See Baker, supra note 46, at 587-89 (surveying procompetitive explanations for prices that might appear to below costs); see also John E. Lopatka \& William H. Page, 'Obvious' Consumer Harm in Antitrust Policy: The Chicago School, the Post-Chicago School and the Courts, in Post-Chicago Developments in Antitrust Law, supra note 6, at 129, 132-36 (noting that courts tend to have sympathy for conduct conferring short-run consumer benefits and hostility for conduct conferring short-run consumer harm, even when careful economic analysis might support a decision otherwise).

${ }_{134}$ Allied Orthopedic Appliances Inc. v. Tyco Health Care Grp., 592 F.3d 991, 1000 (9th Cir 2010). See generally Alan Devlin \& Michael Jacobs, Anticompetitive Innovation and the Quality of Invention, 27 Berkeley TeCh. L.J. 1 (2012) (discussing the relationship between acts of invention and antitrust violations).

${ }^{135}$ In addition to the cognizability issue highlighted in the text, other issues familiar from other antitrust contexts may include the treatment of cost savings that benefit sellers but are not passed through to buyers, and whether or when to count efficiencies that benefit buyers in markets other than the market in which the harm to competition occurs.

${ }^{136}$ To similar effect, one commentator raises the possibility that a monopolist's exclusion of rivals from access to one side of its two-sided platform could be justified by its success in making the platform more effective at attracting buyers on the other side. See Jacobson, supra note 80, at 361 ("'O]ne can imagine a nonfrivolous (albeit weak) argument on behalf of the 
sumption that competition itself is unreasonable," and thus ruled out by the holding of National Society of Professional Engineers, ${ }^{137}$ but dicta in Trinko might appear to call that conclusion into question. ${ }^{138}$

In a general sense, the truncated rule of law explicated above allows condemnation of exclusion as anticompetitive without comprehensive reasonableness upon a showing of three elements: (a) exclusionary conduct, (b) facts suggesting the likelihood of harm to competition; and (c) the absence of a plausible efficiency justification for the exclusionary conduct. The second element would be satisfied by the exclusion of all actual and potential rivals (other than insignificant ones); the open questions raise the possibility that it may also be satisfied in other ways, particularly by excluding-firm market power combined with the ability to foreclose at least one rival, or by actual anticompetitive effects.

Describing the truncated rule for exclusion this way emphasizes its structural similarity to the truncated rule for horizontal restraints applied to collusion, which, as previously discussed, ${ }^{139}$ establishes a violation on a showing of three similar general elements: (a) an agreement among rivals, (b) facts suggesting the likelihood of harm to competition; and (c) the absence of a plausible efficiency justification for the agreement. If the predicates for quick look condemnation are not satisfied, the conduct is subject to unstructured rule of reason review in each case. As a formal matter, therefore, antitrust's doctrinal rules treat plain exclusion and naked collusion comparably; they do not confer a more relaxed scrutiny on exclusionary conduct.

The structured doctrinal rules for exclusion and collusion both require the absence of a plausible efficiency justification as a predicate for truncated condemnation, but the rules differ in their first two elements. Their initial elements are obviously not the same: the exclusion rule is predicated on exclusionary conduct while the collusion rule is predicated on collusive conduct. ${ }^{140}$ As will be examined in detail in Part IV, moreover, the rules also differ in their second element. The facts suggesting that the collusive conduct is anticompetitive, such as price fixing or market division, differ from the

\footnotetext{
Lorain Journal that the value of the newspaper as an advertising medium might be diluted if the same messages were available elsewhere.").

${ }^{137}$ Nat'l Soc'y of Prof'l Eng'rs v. United States, 435 U.S. 679, 696 (1978).

${ }_{138}$ See Verizon Commc'ns Inc. v. Law Offices of Curtis V. Trinko, LLP, 540 U.S. 398, 407 (2004) ("The opportunity to charge monopoly prices — at least for a short period . . . induces risk taking that produces innovation and economic growth. ...").

139 See supra text accompanying notes $82-86$.

${ }^{140}$ The first step could have been stated more broadly and in economic language as requiring coordinated conduct rather than the more narrow concept of agreement among rivals, but, as discussed supra note 83, antitrust law has only limited experience in identifying collusive effects from unilateral conduct or vertical agreements and the modern case law as yet offers little guidance on how to do so.
} 
facts suggesting that the exclusionary conduct is anticompetitive, such as excluding all actual or potential rivals. Yet, as I will explain in Part IV, this difference also does not undermine the formal parallelism between the truncated rules. Rather, the second step operates similarly in both contexts by obviating the need to demonstrate the specific mechanisms by which defendants solve the economic problems of making exclusion or collusion work. Those mechanisms are described in the next Part, which identifies the economic relationship between exclusion and collusion.

\section{THE ECONOMICS OF ANTICOMPETITIVE EXCLUSION}

The harm to competition that arises from exclusion and collusion can be understood within a common economic framework. Indeed, the economic reasons for concern about anticompetitive collusion are substantially the same as the reasons for concern about anticompetitive exclusion.

\section{A. Voluntary and Involuntary Cartels}

To see the economic relationship between exclusion and collusion as means of exercising market power, consider a hypothetical soft drink industry with three participants: Coke, Pepsi, and Royal Crown (RC). One can imagine these three rivals reaching an express or tacit (horizontal) agreement to act collectively as though they were a monopolist, reducing industry output in order to raise price above the competitive level. ${ }^{141}$ This outcome could be termed, for reasons that will become clear, a "voluntary" cartel.

Suppose instead that RC does not want to participate in the voluntary cartel. It would prefer to compete rather than to cooperate. In the merger context, one might describe RC as a "maverick" and be concerned that a merger of RC with Coke or Pepsi would lead to coordinated competitive effects. ${ }^{142}$ More generally, if RC would not go along voluntarily with the cartel that Coke and Pepsi want to create, then Coke and Pepsi could make it go along by raising RC's costs or by making it more difficult for RC to reach customers. ${ }^{143}$ With

\footnotetext{
${ }^{141}$ This discussion adopts the convention common in the economics literature of describing competitive harms in terms of increased prices and a reduction in output. This framework encompasses a wider range of harms than may be apparent. It includes reductions in product quality, which can be understood as increases in the quality-adjusted price. It may also account for reductions in the rate of innovation, as conduct that reduces competition also tends to discourage innovation. See generally Jonathan B. Baker, Beyond Schumpeter vs. Arrow: How Antitrust Fosters Innovation, 74 AnTiTrust L.J. 575, 579 (2007); Carl Shapiro, Competition and Innovation: Did Arrow Hit the Bull's Eye?, in The Rate and Direction of Inventive Activity Revisited 361 (Josh Lerner \& Scott Stern eds., 2012).

${ }_{142}$ See, e.g., Jonathan B. Baker, Mavericks, Mergers and Exclusion: Proving Coordinated Competitive Effects Under the Antitrust Laws, 77 N.Y.U. L. Rev. 135, 140 (2002).

${ }^{143}$ If RC is a prospective entrant, Coke may consider a broader range of exclusionary strategies than would be available if $\mathrm{RC}$ is an incumbent firm. In addition to raising RC's post-entry marginal costs of production and distribution, Coke could also deter RC's entry by making it necessary
} 
higher costs of production or distribution, $\mathrm{RC}$ would be forced to cut back its output and raise price, and so permit Coke and Pepsi to reduce their output and raise their prices without fear that aggressive competition by $\mathrm{RC}$ would undermine their collusive efforts. The upshot is that all three firms would reduce output and raise price, similarly to what would happen if RC went along voluntarily with Coke's and Pepsi's efforts to collude. ${ }^{144}$ Because RC is coerced into participating through the exclusionary conduct of Coke and Pepsi, this outcome can be understood as an "involuntary" (or coerced) cartel. ${ }^{145}$

The "involuntary cartel" terminology is a less natural way of describing the outcome if Coke is a dominant firm (no Pepsi) and RC is forced to exit or deterred from entry, as anticompetitive exclusion under such circumstances would result in the creation of a literal monopolist. ${ }^{146}$ Even in this limiting case, though, the "involuntary cartel" terminology appropriately captures the way the excluding firm forces the excluded rival to do what a cartel participant does voluntarily: avoid aggressive competition. The terminology captures the common adverse economic effect of collusion and exclusion, and focuses attention on it.

As the soft drink example demonstrates and the "involuntary cartel" terminology highlights, exclusion and collusion are complementary methods of obtaining market power. ${ }^{147}$ It does not matter to buyers whether the cartel is

for $\mathrm{RC}$ to make greater sunk investments in order to enter or by credibly committing to increase the post-entry competition that RC expects to face. See supra note 75 . (The latter strategies can still be interpreted as raising RC's marginal costs on the view that a prospective entrant's marginal decision includes whether to enter, not just how much to produce conditional on entry.)

${ }^{144}$ The possibility that competition could be harmed through exclusionary conduct has been well established in the economics literature for decades. E.g., Richard R. Nelson, Increased Rents from Increased Costs: A Paradox of Value Theory, 65 J. PoL. Econ. 387 (1957); Steven C. Salop \& David T. Scheffman, Cost-Raising Strategies, 36 J. Indus. Econ. 19 (1987); Oliver E. Williamson, Wage Rates as a Barrier to Entry; The Pennington Case in Perspective, 82 Q.J. ECON. 85 (1968).

${ }_{145}$ Alternatively, the collusive anticompetitve effects could be described as direct and the exclusionary effects described as indirect. Antitrust Law in Perspective, supra note 25, at 45-49.

146 The "involuntary cartel" terminology also may mislead if Coke is a dominant firm to the extent it (incorrectly) suggests that excluding firms must solve "cartel problems" in order for exclusion to succeed in that case.

${ }^{147}$ Cf. Aaron Edlin \& Joseph Farrell, Freedom to Trade and the Competitive Process (Nat'1 Bureau of Econ. Research, Working Paper No. 16818, 2011), available at http://ssrn.com/ab stract $=1761581$ (collusion and exclusion both harm competition by hindering the process through which buyers and sellers undertake potentially beneficial trades and thereby form improving coalitions). But see Thomas G. Krattenmaker, Robert H. Lande \& Steven C. Salop, Monopoly Power and Market Power in Antitrust Law, 76 Geo. L.J. 241, 249 (1987) (distinguishing "Stiglerian" (collusive) market power and "Bainian" (exclusionary) market power). 
voluntary or involuntary; either way, the same firms collectively reduce output and the price that buyers pay increases. ${ }^{148}$

Exclusion and collusion are also closely related in a second way: they are often and naturally combined by firms exercising market power. ${ }^{149}$ Colluding firms may need to exclude in order for their collusive arrangement to succeed. ${ }^{150}$ They may find it necessary to deter a cheating member through exclusionary conduct, or to exclude fringe rivals or new entrants in order to prevent new competition from undermining their collusive arrangement. ${ }^{151}$ For example, the European Commission found that a citric acid cartel threatened dumping actions against Chinese firms not participating in their collusive arrangement and targeted price cutting at the customers of the Chinese producers to deter those rivals from undermining the cartel. ${ }^{152}$ Indeed, a recent study of multiple cartels found that many "use[ ] exclusionary behavior often featured in monopolization cases to ensure the effectiveness of [their] efforts to restrict output." ${ }^{153}$ Similarly, excluding firms may need to collude in order to exclude successfully ${ }^{154}$ or to profit collectively from exclusionary conduct. ${ }^{155}$

\footnotetext{
${ }^{148}$ In a homogeneous product market, moreover, the exercise of market power reduces industry output, regardless of whether the practice is collusive or exclusionary.

${ }^{149}$ This discussion illustrates the way that exclusion and collusion permit the firms participating in a market to exercise market power within that market. It does not address the potential competitive consequences of monopoly leveraging (the exploitation of market power in one market to create market power in another market), except insofar as entry into a complementary market would facilitate entry into the market served by the excluding or colluding firms, and the excluding or colluding firms can maintain their market power in the primary market by foreclosing entry by new competitors seeking to sell the complementary product.

${ }^{150}$ See Antitrust Law in Perspective, supra note 25, at 235-47 (colluding firms must solve three "cartel problems," which include preventing new competition, for their arrangement to succeed).

${ }^{151}$ See JTC Petroleum Co. v. Piasa Motor Fuels, Inc., 190 F.3d 775, 778 (7th Cir. 1999) (Posner, C.J.) ("JTC, a maverick, was a threat to the cartel-but only if it could find a source of supply . . . ."; see generally Baker, supra note 142, at 188-97. Exclusionary conduct may be necessary for coordination among rivals to succeed, regardless of whether the coordination itself can be challenged as an illegal agreement.

${ }^{152}$ Case COMP/E-1/36.604-Citric Acid, Comm'n Decision, 2002 O.J. (L 239) 18, TIII 116, $119,166$.

${ }^{153}$ Randal D. Heeb, William E. Kovacic, Robert C. Marshall \& Leslie M. Marx, Cartels as Two-Stage Mechanisms: Implications for the Analysis of Dominant-Firm Conduct, 10 CHI. J. INT'L L. 213, 217 (2009).

${ }^{154}$ See Nw. Wholesale Stationers, Inc. v. Pac. Stationery \& Printing Co., 472 U.S. 284, 290-91 (1985) (alleging agreement among rivals to exclude a competitor); see also Hemphill \& Wu, supra note 53.

155 See Brooke Grp. Ltd. v. Brown \& Williamson Tobacco Corp., 509 U.S. 209, $226-27$ (1993) (rejecting predatory pricing claim in part because facts did not support oligopoly recoupment theory).
} 


\section{B. Exclusion AND ECONOMIC GROWTH}

The parallel between voluntary and involuntary cartels provides an economic basis for treating exclusion and collusion as comparably serious antitrust offenses. Indeed, anticompetitive exclusion may be the more important problem because of the particular threat exclusion poses to economic growth.

When antitrust cases address the suppression of new technologies, products, or business models, the disputes are almost always framed as exclusionary conduct allegations. ${ }^{156}$ For example, Microsoft was found to have harmed competition in personal computer operating systems by impeding the development of a new method by which applications software could access operating systems, involving the combination of Netscape's browser and Sun's Java programming language. ${ }^{157}$ The D.C. Circuit explained that "it would be inimical to the purpose of the Sherman Act to allow monopolists free rein to squash nascent, albeit unproven, competitors at will-particularly in industries marked by rapid technological advance and frequent paradigm shifts." 158

Similarly, much of the relief accepted by the Justice Department and the Federal Communications Commission in their concurrent reviews of Comcast's acquisition of NBC Universal programming aimed to protect the development of nascent competition from a new technology, online video distribution, and new business models that could threaten Comcast's market power in cable television. ${ }^{159}$ Exclusionary conduct inhibiting price competition may also harm innovation competition in the same market, as with the

\footnotetext{
${ }^{156}$ See Tim Wu, Taking Innovation Seriously: Antitrust Enforcement if Innovation Mattered Most, 78 Antitrust L.J. 313, 316 (2012) ("[I]f innovation mattered most . . . . [antitrust] enforcement would be primarily concerned with the exclusion of competitors."). But see United States v. Automobile Mfrs. Ass'n, 307 F. Supp. 617, 620-21 (C.D. Cal. 1969) (discussing consent decree settling allegations of conspiracy to suppress automotive pollution control research and development); Michelle Goeree \& Eric Helland, Do Research Joint Ventures Serve a Collusive Function? 5-6 (Institute for Empirical Research in Economics Working Paper No. 1424059, 2012), available at http://www.iew.uzh.ch/wp/iewwp448.pdf (providing empirical evidence that research joint ventures among rivals may facilitate collusion). For this purpose, cases alleging conspiracies to exclude firms adopting new technologies, as through group boycott or predatory pricing, are counted as exclusionary. See, e.g., Fair Allocation System, Inc., 63 Fed. Reg. 43,182 (FTC Aug. 12, 1998) (consent order settling charges that automobile dealers conspired to induce auto manufacturer to foreclosure rival dealer marketing on the Internet).

${ }^{157}$ United States v. Microsoft Corp., 253 F.3d 34 (D.C. Cir. 2001).

${ }^{158} \mathrm{Id}$. at 79.

${ }^{159}$ Applications of Comcast Corporation, General Electric Company, and NBC Universal, Inc., For Consent to Assign Licenses and Transfer Control of Licensees, Memorandum Opinion and Order, 26 FCC Rcd. 48 (2011), available at transition.fcc.gov/FCC-11-4.pdf; see Competitive Impact Statement, United States v. Comcast Corp., No. 1:11-cv-00106 (D.D.C. Jan. 18, 2011), available at http://www.justice.gov/atr/cases/f266100/266158.pdf. The transaction took the form of a joint venture between Comcast and the previous owner of the programming, General Electric, but was treated as an acquisition because Comcast controlled the joint venture and had the option to buy out General Electric.
} 
"exclusionary rules" adopted by MasterCard and Visa to prevent member banks from issuing American Express or Discover Cards. ${ }^{160}$

The anticompetitive exclusion of new technologies is not just a modern problem. Six decades ago, the newspaper monopolist in Lorain Journal impeded the entry of a rival using a new technology, radio. ${ }^{161}$ Had the newspaper succeeded, and other newspapers followed suit, ${ }^{162}$ it is easy to imagine that few radio stations in regions with a dominant newspaper would have succeeded unless they were owned by the newspaper, slowing the growth of the radio industry.

These prominent examples make clear that antitrust is an "inclusive" economic institution that supports economic growth and prosperity by preventing successful incumbent firms and industries from erecting barriers to the entry of rivals with lower costs, superior production technologies, or better products. ${ }^{163}$ The main innovation-related argument otherwise does not question the benefits of economic growth, whether in individual industries ${ }^{164}$ or to society

${ }^{160}$ United States v. Visa U.S.A., Inc., 344 F.3d 229, 241 (2d Cir. 2003) (upholding district court findings that exclusionary conduct stunted price competition and denied consumer access to products with new features, and that absent the exclusionary conduct, price competition and innovation in services would be enhanced).

${ }^{161}$ Lorain Journal Co. v. United States, 342 U.S. 143 (1951).

162 See Kansas City Star v. United States, 240 F.2d 643 (1957) (news and advertising monopolist owned multiple newspapers and radio and television broadcasting stations in the Kansas City region).

163 See Daron Acemoglu \& James A. Robinson, Why Nations Fail 38-40 (2012) (contrasting the growth-promoting economic institutions in the United States with the growth-inhibiting ones in Mexico by comparing Bill Gates, whose technologically innovative company was prevented from abusing its monopoly by U.S. antitrust enforcers, with Carlos Slim, whose company was conferred monopoly power and protected from competition by Mexican government institutions). Acemoglu and Robinson attribute economic growth and prosperity primarily to "inclusive" economic institutions that facilitate entry, investment, and innovation and permit less efficient firms to be replaced by more efficient ones, $i d$. at $75-79$, as opposed to "extractive" economic institutions that "expropriate the resources of the many, erect entry barriers, and suppress the functioning of markets so that only a few benefit." Id. at 81 . In their view, inclusive economic institutions are typically supported by "inclusive" political institutions that vest power in a broad coalition or plurality of political groups rather than in a narrow elite. Id. at 80-81, 86-87; see also Stephen L. Parente \& Edward C. Prescott, Barriers to Riches 1-34 (2000) (attributing differences in living standards across nations importantly to competition-reducing policies within less developed countries, put into place to protect the interests of groups that benefit from current ways of production, that prevent firms from adopting better production methods); cf. Edward L. Glaeser, The Political Risks of Fighting Market Failures: Subversion, Populism and the Government Sponsored Enterprises 8 (Nat'l Bureau of Econ. Research, Working Paper No. 18112, 2012) ("If bargaining across firms is difficult, especially when trying to arrange for large bribes, then competition will lead to less corruption risk than monopoly.").

${ }^{164} \mathrm{At}$ the level of individual industries, studies find substantial social gains from new product introductions. For example, the welfare gain from the introduction of personal computers has been estimated to equal 2-3 percent of consumption expenditure. Jeremy Greenwood \& Karen A. Kopecky, Measuring the Welfare Gain from Personal Computers, 51 Econ. InQuiRy 336, 336 (2013). Compare Jerry A. Hausman, Valuation of New Goods Under Perfect and Imperfect Competition, in 58 NBER Studies in Income and Wealth: The Economics of New Goods 
as a whole; ${ }^{165}$ both skeptics and advocates of antitrust intervention in exclusionary conduct settings such as monopolization are concerned with the impact of competition policy on growth. ${ }^{166}$

Instead, those concerned about antitrust enforcement against exclusionary conduct argue that it could discourage innovation by making it less profitable. Their economic point is that a greater prospect of post-innovation competition could reduce the return to innovation. ${ }^{167}$ But as an argument against antitrust enforcement, it is incomplete because it does not recognize the importance of competitive forces-both pre-innovation product market competition and competition in innovation itself-for fostering innovation and economic growth. ${ }^{168}$ Empirical evidence suggests that the latter forces are more impor-

207, 207-35 (Timothy F. Bresnahan \& Robert J. Gordon eds., 1996) (estimating substantial social welfare gains from the introduction of a differentiated consumer product), with Timothy $\mathrm{F}$. Bresnahan, The Apple-Cinnamon Cheerios War: Valuing New Goods, Identifying Market Power, and Economic Measurement (undated unpublished manuscript), http://www.stanford.edu/ $\sim$ bres/Unpublished_Papers/hausman\%20recomment.pdf (questioning Hausman's methodology and conclusion, but not doubting the likelihood of substantial benefits from new products in high-technology sectors). Moreover, other studies find that the social return to innovation substantially exceeds the private return. See Edwin Mansfield, Microeconomics of Technological Innovation, in The Positive Sum Strategy: Harnessing Technology for Economic GROwTH 307-11 (Ralph Landau \& Nathan Rosenberg eds., 1986); Jeffrey M. Bernstein \& M. Ishaq Nadiri, Interindustry R\&D Spillovers, Rates of Return, and Production in High-Tech Industries, 78 Am. Econ. Rev. 429 (1988); see also Zvi Griliches, The Search for R\&D Spillovers, 94 Scandinavian J. Econ. S29 (1992); Charles I. Jones \& John C. Williams, Measuring the Social Return to R\&D, 113 Q.J. Econ. 1119 (1998).

${ }^{165}$ See generally J. Bradford DeLong, Cornucopia: The Pace of Economic Growth in the Twentieth Century (Nat'l Bureau of Econ. Research Working Paper No. 7602, 2000) (highlighting the benefits of economy-wide increases in material wealth and productivity).

166 Compare David S. Evans \& Keith N. Hylton, The Lawful Acquisition and Exercise of Monopoly Power and Its Implications for the Objectives of Antitrust, 4 COMPETITION POL'y INT'L 203, 203 (2008) (arguing that antitrust pays excessive attention to the static harms of monopoly pricing and insufficient attention to the dynamic benefits of dominant firm innovation), with Jonathan B. Baker, "Dynamic Competition" Does Not Excuse Monopolization, 4 Competition POL'y INT'L 243, 243-45 (2008) (describing innovation benefits of antitrust enforcement against monopolization).

${ }^{167}$ For example, in the model analyzed by Hylton and Lin, antitrust enforcement against the exclusionary conduct of dominant firms benefits society by lowering post-innovation consumer prices, but harms society by discouraging innovation. See Keith N. Hylton \& Haizhen Lin, Optimal Antitrust Enforcement, Dynamic Competition, and Changing Economic Conditions, 77 ANTITRUST L.J. 247, 255 (2010). The model does not incorporate the dynamic benefits of preinnovation competition in providing an incentive to innovate. See generally Verizon Commc'ns Inc. v. Law Offices of Curtis V. Trinko, LLP, 540 U.S. 398, 407 (2004) (the prospect of monopoly induces risk-taking and innovation).

${ }^{168}$ See generally Baker, supra note 141, at 579; Shapiro, supra note 141; cf. TIM Wu, The Master Switch: The Rise and Fall of Information Empires 308 (2010) ("To grant any dominant industrial actor the protection of the state, for whatever reason, is to arrest the Schumpeterian dynamic by which innovation leads to growth, an outcome that is ultimately never in the public interest."); Wu, supra note 156, at 320 ("[A]n innovation-centered antitrust policy must make scrutiny of exclusion of innovators its primary concern and a focus of resources.”). 
tant on average. ${ }^{169}$ As an argument against antitrust, the observation also does not recognize the way antitrust enforcement can target industry settings and categories of behavior where such enforcement can promote innovation. ${ }^{170}$ Those settings include antitrust enforcement to foster product market competition in "winner-take-all" or "winner-take-most" industries, industries where the extent of future competition will be determined mainly by developments in technology or regulation, and rapidly growing industries ${ }^{171}$-all features that frequently characterize high technology sectors. ${ }^{172}$ In short, antitrust enforcement against exclusionary conduct is important because it fosters economic growth and prosperity, not just because it addresses harms to price competition similar to those attacked by enforcement against collusive conduct.

\section{DIFFERENCES BETWEEN EXCLUSION AND COLLUSION}

Notwithstanding the broad doctrinal and economic parallels between voluntary and involuntary cartels, anticompetitive collusion and exclusion arise through different mechanisms. This section explains why those differences do not mean that that antitrust enforcers or courts should downplay exclusion relative to collusion. It also shows that the truncated legal rules for exclusion and collusion operate similarly: by making it unnecessary to demonstrate some or all elements of the relevant mechanisms.

\section{A. The Economics of "Exclusion Problems"}

For an exclusionary strategy to succeed, and thus for the excluding firms successfully to create an involuntary cartel, the excluding firms must solve three problems: identifying a practical method of exclusion, excluding rivals sufficient to ensure that competition is harmed, and ensuring profitability of

${ }^{169}$ See Baker, supra note 141, at 583-87; Shapiro, supra note 141.

${ }^{170}$ See Baker, supra note 141, at 589; see also Baker, supra note 166 (describing innovation benefits of antitrust enforcement against monopolization).

${ }^{171}$ See Baker, supra note 141, at 593-98. Policies increasing pre-innovation competition in these industries - such as monopolization cases or other antitrust enforcement actions- are unlikely to make much difference to the reward to successful innovation-but can increase preinnovation competition in both product markets and in innovation, and thus increase overall incentives to innovate.

${ }^{172}$ Anticompetitive conduct, whether exclusionary or collusive, can occur in rapidly-innovating high-technology industries, as illustrated by recent government enforcement efforts involving information technology providers. See, e.g., United States v. Microsoft Corp., 253 F.3d 34 (D.C. Cir. 2001) (exclusion); United States v. Adobe Sys., Inc., No. 1:10-cv-01629 (D.D.C. Mar. 18, 2011) (final judgment), available at http://www.justice.gov/atr/cases/f272300/272393.htm (collusion); United States v. Hynix Semiconductor, Inc., No. CR 05-249 PJH DRAM (N.D. Cal. May 11, 2005) (plea agreement), available at http://www.justice.gov/atr/cases/f209200/209231. pdf (collusion); Intel Corp., FTC Docket No. 9341 (Aug. 4, 2010) (decision and order), available at http://www.ftc.gov/os/adjpro/d9341/100804inteldo.pdf (exclusion). 
their exclusionary strategy. ${ }^{173}$ These three problems - method, sufficiency, and profitability - may be termed "exclusion problems" 174 by analogy to the "cartel problems" that colluding firms must solve in order for a coordinated arrangement to succeed. ${ }^{175}$

First, the excluding firms must be able to identify a method of partially or fully excluding some or all rivals. ${ }^{176}$ The possible methods include four economic mechanisms for raising rivals' marginal input costs described by Professors Krattenmaker and Salop. ${ }^{177}$ First, excluding firms may create a "bottleneck." 178 The excluding firms can do so by purchasing exclusionary rights from a sufficient number of the lowest cost suppliers to force excluded rivals to shift to higher cost suppliers or less efficient inputs. The cost increase leads the excluded rivals to compete less aggressively with the excluding firms. Second, excluding firms may engage in "real foreclosure." 179 Under this method, excluding firms purchase exclusionary rights over a substantial fraction of the supply of a key input, and, by withholding that supply, drive up the market price for the remainder of the input still available to excluded rivals. Again, higher costs would lead the excluded rivals to compete less aggres-

173 These exclusion problems were identified by Professors Krattenmaker and Salop in their seminal survey article on exclusionary conduct in antitrust. See Krattenmaker \& Salop, supra note 9, at 230-49. In that article, Krattenmaker and Salop refer to the first exclusion problem (method) as "raising rivals' costs," $i d$. at 230, to the second problem (sufficiency) as "gaining power over price," $i d$. at 242 , and to the third exclusion problem as "profitability," using the same term employed here, $i d$. at 266. The three exclusion problems set forth in the text also generalize the three conditions described as necessary for successful exclusion through vertical agreement set forth in Baker, supra note 74, at 524, which explains that the benefits of the strategy to the firms undertaking it must exceed its costs (profitability), the excluding firms must not cheat on each other (an aspect of sufficiency), and the excluded firm must be unable to avoid the strategy (method).

${ }^{174}$ When there are multiple excluding firms, solving the first and second "exclusion problems" could require coordination among rivals, further illustrating the close connection between collusion and exclusion. See Hemphill \& Wu, supra note 53 (discussing the ways excluding firms solve their "cartel problems").

175 As is well known, colluding firms must find a way to solve three "cartel problems": reaching consensus on terms of coordination, deterring cheating on those terms, and preventing new competition. See Antitrust Law in Perspective, supra note 25, at 235-47. These problems emerge from the Stiglerian deterrence perspective on coordination (as refined by the economic literature on oligopoly supergames). See Baker, supra note 25, at 149-69 (describing economics of coordination). They are not tied to the broader perspective on coordination adopted by the 2010 Horizontal Merger Guidelines. The Guidelines go beyond the Stiglerian perspective by also recognizing as coordination "parallel accommodating conduct" (high price outcomes that result from firm conduct that softens competition when firm strategies do not depend on history and rivals have accommodating reactions). See U.S. Dep't of Justice \& Fed. Trade Comm'n, Horizontal Merger Guidelines § 7 (2010), available at http://www.justice.gov/atr/public/guidelines/ hmg-2010.pdf.

${ }^{176}$ Methods arising in the case law are surveyed informally supra Part II.A.

177 See Krattenmaker \& Salop, supra note 9, at 234-40.

$178 \mathrm{Id}$. at 234.

${ }^{179} I d$. at 236. 
sively. Third, the excluding firms may act as a "Cartel Ringmaster" by inducing multiple suppliers of a key input to sell to the excluded rivals only on disadvantageous terms, thereby reducing competition from those rivals. ${ }^{180}$ Fourth, the excluding firms may create a "Frankenstein Monster." 181 The excluding firms would do so by purchasing exclusionary rights from a number of suppliers of the key input, thereby increasing the likelihood that the remaining suppliers would successfully collude, expressly or tacitly, to raise price to the excluded rivals. With higher input prices, the excluded rivals would once again be led to compete less aggressively.

The economic mechanisms by which excluding firms foreclose their rivals could work through raising input prices (input foreclosure), as with the four methods just set forth, but they could also operate by reducing rivals' access to the market (customer foreclosure). For example, if the rivals benefit from scale economies and the excluding firms adopt methods that foreclose the excluded rivals from access to low cost distribution, the excluding firms may raise their rivals' costs by reducing their rivals' scale. ${ }^{182}$ Indeed, any economic mechanism available for input foreclosure is potentially available for customer foreclosure, and vice versa. ${ }^{183}$

If the excluded firms can inexpensively adopt counterstrategies to avoid or evade the exclusionary conduct, the excluding firms will be unable to solve the first exclusion problem, identifying an exclusionary method. ${ }^{184}$ In the hypothetical soft drink example sketched in Part III.A, if Coke and Pepsi attempt to exclude RC by denying it access to bottlers, but RC can instead obtain comparable distribution through beer distributors at little cost penalty, ${ }^{185}$ the exclusionary strategy would not be successful. ${ }^{186}$ Moreover, if the method of

${ }^{180} I d$. at 238 .

${ }^{181} I d$. at 240.

182 If the excluded rivals must produce and sell at a reduced scale, they may have higher marginal costs. If the excluded rivals can no longer achieve a minimum viable scale, those rivals would be forced to exit.

${ }^{183}$ Some conceptual gymnastics may be required to see the parallel. Consider, for example, an industry with firms at three levels: input supply, manufacturing, and distribution. Distribution may more naturally be seen as downstream of manufacturing, but it would not be inappropriate to view it alternatively as a service purchased by the manufacturer. Hence conduct excluding a rival from access to distribution could be viewed as input foreclosure as well as customer foreclosure. See also supra note 54.

${ }^{184}$ Krattenmaker and Salop analyze rivals' counterstrategies solely as a profitability issue; here that issue is also treated as an aspect of the first exclusion problem.

185 This counterstrategy would be unlikely to be available, however, unless beer distributors can produce bottled products from concentrate.

186 Although customers may have an incentive to help the excluded firms avoid foreclosure, see David T. Scheffman \& Pablo T. Spiller, Buyers' Strategies, Entry Barriers, and Competition, 30 ECON. INQuiRy 418 (1992), they need not be able or willing to do so. Customers' ability to assist excluded firms in executing a counterstrategy is unlikely to be greater than their ability to undermine a voluntary cartel by sponsoring entry. In a market with many buyers, for example, no 
exclusion requires coordination between Coke and Pepsi, the inquiry into method of exclusion would also include asking whether those firms could successfully coordinate. ${ }^{187}$

Second, the exclusionary conduct must be sufficient to harm competition. This condition requires in part that the excluded firm matter competitively; ${ }^{188}$ its exclusion must relax a competitive constraint on the excluding firms. ${ }^{189}$ In addition, it requires that any remaining competition-whether from rivals not excluded or not fully excluded, from entrants, or from among the excluding firms themselves - not undermine what the relaxation of a competitive constraint has achieved for the excluding firms: their ability to raise market prices. Accordingly, the excluding firms must prevent their involuntary cartel from being undermined through repositioning or output expansion by unexcluded rivals, by the entry of new competitors, or by cheating among the excluding firms. In a prospective exclusion case, the ability of excluding firms to solve the sufficiency problem might be inferred from an analysis of market structure, ${ }^{190}$ or from past history of successful exclusion. In a retrospective

individual customer may have sufficient incentive to sponsor entry: doing so would be costly and each buyer would recognize that most of the benefits would accrue to other buyers rather than itself.

187 With multiple excluding firms, the excluding firms may have difficulty committing to their exclusionary method, as they may be unable to avoid the temptation to cheat on the involuntary cartel they have created by foreclosing their excluded rivals. The analysis of whether the excluding firms can successfully overcome this problem, an aspect of sufficiency, would be similar to the analysis of whether the excluding firms would cheat on the collusive arrangement that would have formed had the excluded firms joined the excluding firms voluntarily. This issue would not arise if there is only a single excluding firm, as would be the case if Coke was a dominant firm.

188 See Joshua D. Wright, Moving Beyond Naïve Foreclosure Analysis, 19 GEO. MAson L. REV. 1163, 1186-87 (2012) (recommending that the share foreclosed by the adoption of an exclusionary rights agreement be measured relative to the share foreclosed but for the adoption of the agreement).

189 An excluded firm can constrain the excluding firms competitively even if it is not as efficient as the excluding firms. For example, if the industry price is $\$ 18$, the excluding firms have marginal costs of $\$ 10$, and the sole excluded firm has a marginal cost of $\$ 15$, competition would be harmed if the excluding firms raise the price to \$20 (say) through foreclosure of the excluded firm, even though the excluded firm has a higher marginal cost than the excluding firms. In this example, the exclusionary conduct would both raise price to consumers and increase the allocative efficiency loss that arises when price exceeds marginal cost. If foreclosure of an inefficient firm allows a lower cost firm to expand output in its place, as may or may not occur, the resulting production cost savings would create a countervailing benefit to aggregate welfare (although that benefit would not be cognizable if the welfare criterion looks solely to consumers).

${ }^{190}$ If the exclusionary conduct is undertaken by a dominant firm, for example, and the dominant firm excludes all significant fringe rivals (those that are not capacity-constrained or otherwise have a high cost of expansion) and entrants, the dominant firm would not face any competitive threats. This simple economic idea underlies the truncated legal rule governing exclusionary conduct discussed in Part II.B. The second and third open questions about the rule governing truncated condemnation of exclusionary conduct suggest some ways of making this inference other than analyzing the consequences of excluding firm conduct for each actual and potential rival individually. Supra notes 121-128 and accompanying text. 
exclusion case, where market definition may be more difficult, ${ }^{191}$ evidence of actual competitive effects may also be available. ${ }^{192}$

Finally, the exclusionary conduct must be profitable for each excluding firm. ${ }^{193}$ Each must reasonably expect that the additional profits it will obtain or maintain through the successful operation of an involuntary cartel would exceed the costs it incurs in achieving that arrangement. ${ }^{194}$ The costs might include, for example, payments to sellers of complements that agree to exclude rivals, forgone revenues from reducing price below what the excluding firms might otherwise charge (e.g., if predatory pricing is alleged as the exclusionary mechanism), or forgone profits on lost sales (e.g., if the excluding firms refuse to deal with buyers that deal with a rival). ${ }^{195}$ In a retrospective exclusion case, profitability might be inferred from observing higher prices or other harms to competition.

The costs of exclusion, and thus the profitability of anticompetitive exclusionary conduct, depend upon the nature and scope of the method used to exclude. ${ }^{196}$ Exclusionary strategies need not be expensive. ${ }^{197}$ A dominant firm's unilateral refusal to deal with suppliers that also supply an entrant or fringe rival, for example, may not be costly if few or no suppliers defect to

${ }^{191}$ See generally Baker, supra note 101, at 169-73 (discussing problems that arise in defining markets in exclusion settings).

192 This possibility underlies the fourth open question about the truncated legal rule governing exclusionary conduct. See supra notes 129-131 and accompanying text.

${ }^{193}$ Krattenmaker and Salop's notion of profitability includes an evaluation of efficiency justifications. See Krattenmaker \& Salop, supra note 9, at 277-82. Efficiencies potentially affect profitability to the extent ancillary efficiencies reduce the costs and increase the benefits of exclusion. Efficiencies are also possible means by which the excluding firms would justify otherwise harmful conduct. Hence, the truncated rule governing exclusionary conduct set forth in Part IV.B requires the absence of a plausible efficiency justification, and efficiencies are considered as part of a comprehensive reasonableness analysis (as would be undertaken if the truncated rule does not apply).

${ }^{194}$ When predatory pricing is the exclusionary instrument, this problem is termed "recoupment" because the excluding firms bear the cost of exclusion before they earn the rewards. The prospects for profitability may be challenging to demonstrate in a case that is brought after the excluding firms have incurred costs of exclusion but before the profits they may earn can be observed, as may occur with predatory pricing. But profitability may be easier to evaluate when the profits from exclusion arise coincident with the costs, as in many non-price exclusion settings.

195 The costs may also include any expense associated with solving "cartel problems" if multiple excluding firms must coordinate in order to exclude rivals or raise price once that exclusion has occurred. Ancillary benefits to the excluding firms of pursuing exclusionary conduct, such as efficiencies, could reduce the net costs of implementing the method of exclusion.

${ }^{196}$ When exclusion is coordinated, moreover, the costs and benefits of exclusion may differ among the excluding firms. See Baker, supra note 46, at 601-02 (noting that one firm may have borne a disproportionate fraction of the costs and earned the bulk of the benefits of an alleged predatory pricing conspiracy among cigarette manufacturers).

${ }^{197}$ See generally Creighton et al., supra note 81. 
dealing with the rival. ${ }^{198}$ Even when it is expensive for the excluding firms to foreclose their excluded rivals, moreover, the prospective monopoly profits the excluding firms obtain from successfully obtaining or protecting market power may be great enough to make the expenditure worthwhile. ${ }^{199}$

\section{B. Profitability of Purchasing an Exclusionary Right}

The recent economic literature on exclusionary conduct has paid particular attention to identifying conditions under which one exclusionary method, the purchase of an exclusionary right, would be profitable for the excluding firms ${ }^{200}$ - thus explaining how the excluding firms solve the third "exclusion problem" using this strategy. ${ }^{201}$ A firm purchases an exclusionary right when it pays a supplier or distributor (or other seller of complements) not to deal with one or more of the excluding firm's rivals. ${ }^{202}$ The arrangement could be express, as with Alcoa's contracts with hydroelectric power producers to prevent the generators from supplying electricity to other aluminum manufacturers, ${ }^{203}$ or Microsoft's agreements with Internet access providers to limit

198 See, e.g., Lorain Journal Co. v. United States, 342 U.S. 143 (1951).

${ }^{199}$ See generally Krattenmaker \& Salop, supra note 9, at 273-77 (noting that rivals benefiting from an involuntary cartel may find it necessary to share their monopoly profits with sophisticated input suppliers).

200 The analysis of the profitability of this exclusionary strategy is complicated by the need to account for the interaction between the excluding firms and the vertically related firms (or other sellers of complements) that agree not to deal with the excluded firms or otherwise foreclose them.

${ }^{201}$ Other exclusionary methods, not discussed in detail here, may resemble the purchase of an exclusionary right because they may also involve contracts or understandings between the excluding firm and sellers of complements. These may include "most favored nations" (MFN, or "most favored customer") clauses, which can be employed by dominant firms to ensure that fringe rivals and entrants cannot lower their costs by obtaining lower prices from sellers of complements, bundled (or loyalty) discounts (or rebates) offered by manufacturers to dealers, slotting allowances, and resale price maintenance. To the extent these methods operate like the purchase of an exclusionary right, the economic analysis in the text is likely relevant to understanding their competitive implications. See John Asker \& Heski Bar-Isaac, Vertical Practices Facilitating Exclusion (NYU Working Paper, 2012) available at http://ssrn.com/abstract=218182 (a manufacturer can employ a range of vertical practices to share profits from its exercise of market power with its dealers, thereby giving the dealers an incentive not to deal with an entrant into manufacturing); cf. Timothy J. Brennan, Getting Exclusion Cases Right: Intel and Beyond, CPI ANTitrust Chronicle 5-7, Dec. 2011 (1), available at https://www.competitionpolicyinter national.com/dec-11 (exclusionary conduct that operates by suppressing competition in the market for a complementary product can profit firms selling complements). (In other settings, though these practices may harm competition through means other than exclusion (including facilitating collusion, dampening competition, or facilitating anticompetitive price discrimination), or they may permit firms to achieve efficiencies.)

202 Although the discussion below will be framed by an example in which the excluded firm was cut off from the supply of a key input, the same analysis would apply if the excluded firm was cut off from an important distribution channel.

${ }^{203}$ See United States v. Aluminum Co. of Am., 148 F.2d 416, 422-23 (2d Cir. 1945) (Alcoa) (describing agreements addressed in a 1912 government antitrust enforcement action). 
distribution of Netscape's browser. ${ }^{204}$ The arrangement could also be tacit, as when a manufacturer pays a generous wholesale price to a supplier and the supplier returns the favor by not dealing with one or more rival manufacturers. ${ }^{205}$

Several factors affect the profitability of exclusion through the purchase of an exclusionary right. ${ }^{206}$ Some of these factors were addressed by the Seventh Circuit in JTC Petroleum Co. v. Piasa Motor Fuels, Inc. ${ }^{207}$ In that case, the court evaluated the plausibility of an alleged bid-rigging scheme in which the defendant producers were said to have protected their collusive arrangement by inducing suppliers of a key input to refuse to sell that input to JTC, a maverick rival that otherwise would have cheated on the cartel. The appellate court overruled the district court's award of summary judgment to defendants, holding that a rational jury could conclude that the excluded firm was the victim of a supplier boycott organized by its rivals.

The four factors set forth below presume that a dominant firm is engaged in the exclusionary conduct, without addressing the additional complications that arise when firms coordinate to purchase exclusionary rights, as was alleged in JTC Petroleum. Instead, the discussion will suppose that one of the alleged excluding firms in the case, Piasa, paid asphalt suppliers not to supply one of Piasa's rival's, JTC. This arrangement could have been negotiated explicitly and memorialized contractually, or it could have been informal and tacit, as might arise if Piasa paid generously for its asphalt purchases while simultaneously making clear to the supplier the high value it places on supplier loyalty. ${ }^{208}$

${ }^{204}$ United States v. Microsoft Corp., 253 F.3d 34, 67-68 (D.C. Cir. 2001) (en banc).

${ }^{205}$ See, e.g., JTC Petroleum Co. v. Piasa Motor Fuels, Inc., 190 F.3d 775, 778 (7th Cir. 1999) (Posner, C.J.) (noting that cartel members may have induced suppliers to refuse to sell to the cartel's maverick rival by paying a higher price for the supplied product).

206 See generally Michael D. Whinston, Lectures on Antitrust Economics 133-97 (2006) (surveying the economic literature on exclusionary vertical contracts, with attention to antitrust applications); Claudia M. Landeo, Exclusionary Vertical Restraints and Antitrust: Experimental Law and Economics Contributions, in Research Handbook on Behavioral Law AND ECONOMics (Kathryn Zeiler \& Joshua Teitelbaum eds., forthcoming) (surveying the experimental economic literature on exclusionary vertical contracts, with attention to antitrust applications).

${ }^{207}$ JTC Petroleum, 190 F.3d 775. The terminology employed here highlights the vertical structure of the exclusionary contracts but may be confusing to a reader familiar with the opinion. In the opinion, the firms described here as producers are termed "applicators" (they are road contractors), and the firms described here as suppliers are termed "producers" (because they produce asphalt for use by the applicators). Id. at 776.

${ }^{208}$ An informal or tacit exclusionary arrangement presents an additional difficulty not present if the exclusionary right is purchased through a contract. Piasa might wish to subsidize one or more suppliers as an implicit quid pro quo for exclusivity, perhaps by paying generously for its own input purchases. But Piasa could not profitably do so if the suppliers would act opportunistically (by taking the payment without following through by cutting off JTC), as the resulting competition between Piasa and JTC would lower Piasa's profits. However, the suppliers would 
The first factor is the relative profitability of success for Piasa and JTC. For Piasa, success would mean excluding JTC and thus obtaining or maintaining market power. For JTC, success would mean participating in the market by avoiding exclusion. The relative profitability of success matters because the firm with the greater financial advantage should its strategy succeed is better positioned to win a bidding war over whether the supplier will sell asphalt to JTC. Piasa may have a financial advantage arising from the monopoly profits it would earn if it successfully excluded JTC, ${ }^{209}$ while JTC may have a financial advantage if can produce at lower cost than Piasa. ${ }^{210}$ In the JTC Petroleum case, the Seventh Circuit addressed this factor by explaining that the cartel profits could have given the producers a fund with which to compensate the input suppliers. ${ }^{211}$

The second factor affecting the profitability to Piasa of purchasing an exclusionary right from an input supplier is Piasa's ability to limit the scope and cost of its investments in exclusion through careful targeting. ${ }^{212}$ For example, if Piasa must pay the supplier to deal with Piasa exclusively, and thus pay it not to sell to a wide range of other firms (perhaps including rivals to Piasa and firms producing in geographic markets other than those in which Piasa and JTC compete), Piasa may have to pay more than it would pay to induce the supplier not to sell to just one firm, JTC. Piasa was more likely to find the

not necessarily act opportunistically, for example if they fear that Piasa would respond by not purchasing from them.

${ }^{209}$ Piasa would no longer have that advantage if JTC would reasonably expect that if it manages to avoid exclusion, Piasa would not compete aggressively against it. See Chiara Fumagalli \& Massimo Motta, Exclusive Dealing and Entry, When Buyers Compete, 96 Am. Econ. Rev. 785 (2006) (noting that if a successful entrant would be likely to take a substantial fraction of the market from a dominant incumbent, distributors may see greater benefit in dealing with the entrant than they would if the entrant's prospects were more limited).

${ }^{210}$ JTC might have a more efficient production technology or better business model, for example. In other settings, the excluded firm's financial advantage should it successfully enter might come from its ability to offer an attractive new or improved product. Even if JTC has substantial financial resources, moreover, its ability to convince suppliers to sell it asphalt will also depend on the extent to which an individual supplier would expect to share in the profits from JTC's marketplace success. The more that competition among asphalt suppliers to serve JTC would be expected to dissipate supplier profits, the less interest a supplier would have in serving JTC rather than accepting Piasa's request for exclusivity. See Whinston, supra note 206, at 148-49; John Simpson \& Abraham L. Wickelgren, Naked Exclusion, Efficient Breach, and Downstream Competition, 97 Am. Econ. Rev. 1305 (2007).

${ }^{211}$ JTC Petroleum, 190 F.3d at 778. There was no suggestion that the excluded firm was an efficient producer that would have earned higher profits in a competitive market than the alleged cartelists would have obtained through successful bid-rigging. See id.

${ }^{212}$ See Claudia M. Landeo \& Kathryn E. Spier, Naked Exclusion: An Experimental Study of Contracts with Externalities, 99 AM. Econ. Rev. 1850 (2009) (discrimination by incumbent seller facilitates exclusion); Patrick DeGraba, Naked Exclusion by a Dominant Supplier: Exclusive Contracting and Loyalty Discounts (Fed. Trade Comm'n, Working Paper No. 306, 2010), available at http://www.ftc.gov/be/workpapers/wp306.pdf (a dominant input supplier can prevent a smaller rival from expanding by using exclusive contracts and price discriminating based on an end user's likelihood of purchasing products made with the rival's input). 
strategy of purchasing an exclusionary right to be profitable if it could exclude JTC cheaply. ${ }^{213}$ This factor was not addressed explicitly in the Seventh Circuit's JTC Petroleum decision, perhaps because the alleged exclusionary conduct in that case targeted only the maverick rival and was not so broad in scope as to call into question the profitability of this exclusionary strategy.

The third factor affecting the profitability of exclusion through purchase of an exclusionary right is whether the suppliers expect Piasa to succeed in excluding JTC. This factor would matter most if there were many suppliers (or, equivalently, many distributors), and the excluded rival (JTC) must obtain the key input from several suppliers (but not necessarily all) in order to succeed. Under such circumstances, each supplier's decision to contract with Piasa not to deal with JTC - and the price it will demand from Piasa in order to exclude JTC - may depend on each supplier's expectations about JTC's likely success in reaching a deal with other suppliers. ${ }^{214}$ If each supplier thinks that JTC is unlikely to find enough supply to compete successfully by contracting with

${ }^{213}$ To similar effect, Alcoa apparently targeted entry by rival aluminum producers by contracting with hydroelectric power producers to prevent the generators from supplying electricity to other aluminum manufacturers. The contracts were targeted because they did not preclude the power producers from selling electricity to firms producing other products. See United States v. Aluminum Co. of Am., 148 F.2d 416, 422-23 (2d Cir. 1945) (Alcoa) (describing agreements addressed in a 1912 government antitrust enforcement action). Selective price matching may also operate as a targeted exclusionary strategy. For example, a manufacturer may exclude a rival by matching any price reduction that the rival offers customers with a comparably low price. That strategy would be targeted if the manufacturer only cuts price to those customers solicited specifically by the excluded rival. But if the manufacturer cannot commit to limited targeting in response to competition, and must fight an aggressive rival with an (expensive) across-the-board price reduction, then the exclusionary price-cutting strategy may not be profitable. $C f$. MichaEL E. Porter, Competitive Advantage 500-01, 511 (1985) (recommending "plac[ing] potential challengers at a relative cost disadvantage" by "targeting" price cuts on "products that are likely initial purchases by new buyers" or by "localizing" the response to rival price cutting "to particularly vulnerable buyers" rather than across-the board to reduce the cost of the response); BRUCE Greenwald \& Judd Kahn, Competition Demystified 231 (2005) (recommending than an incumbent respond to entry by "punish[ing] the newcomer as severely as possible at the lowest possible cost to itself"). But see Judith R. Gelman \& Steven C. Salop, Judo Economics: Capacity Limitation and Coupon Competition, 14 Bell J. ECon. 315, 316 n.2 (1983) (noting that even small sunk expenditures may be sufficient to prevent entry by serving as a credible commitment to post-entry competition across-the-board). I am grateful to Aaron Edlin for sharing his insights into the exclusionary potential of price-matching by incumbent firms.

${ }^{214}$ Supplier expectations may depend on the nature of the interdependence among their decisions. One supplier's decision to contract with JTC may confer a positive externality on other suppliers, as by making it more likely that JTC's strategy to compete will succeed. For example, each supplier's agreement to supply JTC may make it more likely that JTC will convince enough other suppliers to do so, and in consequence, may make it more valuable for each undecided supplier to agree to supply JTC. In other settings, however, the decision by one supplier to contract with JTC would reduce the sales and profits available to other suppliers, conferring a negative externality that lessens other suppliers' gains from contracting with JTC. Supplier expectations may also depend on whether the excluding firms can improve their odds of success by supplementing the strategy of purchasing an exclusionary right with additional strategies for raising rivals' costs or reducing their access to the market. 
other suppliers, it would do better by accepting a payment from Piasa for exclusivity-even if it gets little or nothing for doing so-than by contracting with JTC. ${ }^{215}$ The critical role of supplier expectations in this dynamic may mean that the greater the number of suppliers JTC needs to contract with for viability, the less likely that any individual supplier would expect JTC to succeed and, thus, the more likely that each supplier would agree with Piasa not to deal with JTC. ${ }^{216}$

The JTC Petroleum opinion did not address this factor explicitly, presumably because there were only three suppliers, and JTC would likely succeed if it contracted with any one of them. But the opinion did consider supplier expectations by providing three possible reasons why no supplier would act against the cartel's wishes: the cartel might be able to coerce the suppliers by threatening to exercise monopsony power, the cartel's payments to the suppliers may have been too large to resist, and the suppliers themselves may have colluded (as plaintiffs had alleged), so each supplier's individual decision not to sell to the maverick producer may also have been supported by the threat of punishments from the other suppliers. ${ }^{217}$ These possibilities suggest ways that Piasa could have succeeded in excluding JTC by influencing supplier expectations if JTC had needed to assemble multiple suppliers in order to compete.

The final factor affecting the profitability of Piasa's purchase of an exclusionary right is the relative ability of Piasa and JTC to make credible commitments to the suppliers. Piasa's bargaining position with the suppliers would be improved if it can commit that it will not purchase from suppliers that sell to JTC. ${ }^{218}$ If Piasa can convince the suppliers that they must choose between it and JTC - that Piasa will follow through on its intention not to buy from suppliers that sell to JTC - then the suppliers may prefer to work with Piasa by cutting off JTC even if Piasa offers little or nothing in payment for exclusivity. But if the suppliers think that in the event they sell to JTC, Piasa would prefer to continue to purchase from them notwithstanding Piasa's displeasure with their decision to do business with JTC, then Piasa will have to pay more

${ }^{215}$ If JTC needs multiple suppliers to survive but each supplier thinks the other suppliers will accept an exclusive deal with Piasa, no supplier would break ranks to deal with JTC even if Piasa pays nothing. After all, a supplier that expects JTC to fail would not want to ruin its relationship with Piasa by contracting with JTC.

${ }^{216}$ Although the pure "naked exclusion" model has two equilibria, one in which all bottlers agree to exclusivity with Piasa and one in which none do so, the exclusion equilibrium dominates if Piasa can convince even a small number of suppliers not to deal with JTC. See Rasmusen et al., supra note 80, at 1143-44; Ilya R. Segal \& Michael D. Whinston, Naked Exclusion: Comment, 90 Am. Econ. Rev. 296 (2000).

217 JTC Petroleum Co. v. Piasa Motor Fuels, Inc., 190 F.3d 775, 778-79 (7th Cir. 1999) (Posner, C.J.).

${ }^{218}$ Cf. Steven C. Salop \& R. Craig Romaine, Preserving Monopoly: Economic Analysis, Legal Standards, and Microsoft, 7 Geo. Mason L. Rev. 617, 640-42 (1999) (discussing credibility of predatory threats by a dominant firm). 
to induce the suppliers not to deal with JTC, possibly making it uneconomic for Piasa to employ this exclusionary strategy. ${ }^{219}$ The court did not explicitly consider this factor, but it implicitly addressed the credibility of cartel threats not to purchase from suppliers that sell to JTC and other maverick producers by suggesting the possibility that the colluding producers had coerced the suppliers.

The three exclusion problems (means, sufficiency, and profitability) differ from the three cartel problems (reaching consensus, deterring deviation, and preventing new competition) because the mechanisms by which firms achieve an involuntary cartel and a voluntary one are not the same. ${ }^{220}$ But as will be seen in the next Part, the legal rules governing structured review of alleged exclusionary and collusive conduct limit the factors that a court must consider before truncated condemnation in analogous ways-providing additional support for the conclusion that antitrust doctrine treats anticompetitive exclusion and anticompetitive collusion as comparably serious offenses.

\section{Exclusion Problems and Truncated Reasonableness Review}

The economic logic underlying truncated reasonableness review is clarified by recognizing that firms may obtain or maintain market power by solving exclusion problems or collusion problems. The structured rules that permit condemnation of exclusionary or collusive conduct, described above in Part II.B, prove harm to competition through limited factual showings. ${ }^{221}$ In the collusion context, plaintiff may rely on facial analysis or categorization of the agreement (as price fixing or market division), or on actual effects evidence. ${ }^{222}$ In the exclusion context, plaintiff may rely, at a minimum, on evidence that all actual or potential rivals other than insignificant competitors have been excluded. ${ }^{223}$

\footnotetext{
${ }^{219}$ On the other hand, if JTC can commit to limiting its output (as by adopting a high-cost or capacity-constrained production process, or locating its facilities so it can only serve some customers inexpensively), then Piasa may conclude that it would be less costly to allow JTC to enter rather than spend what would be required to prevent JTC from obtaining key inputs. See Gelman \& Salop, supra note 213, at 315.

${ }^{220}$ The problems may overlap, however, if colluding firms must solve their exclusion problems in order to prevent new competition by rivals or entrants, or if multiple excluding firms must solve their cartel problems in order to exclude.

221 Both rules have two elements other than harm to competition. Each incorporates a conduct predicate-exclusion in one case, agreement in the other-and each requires the absence of a plausible efficiency justification for the exclusionary conduct or collusive arrangement at issue.

222 See supra notes 84-86 and accompanying text.

${ }^{223}$ See supra note 97 and accompanying text. Some of the open questions ask whether two other limited forms of proof, actual effects evidence and excluding firm market power, could also be sufficient to demonstrate harm to competition. See supra notes 121-122, 129-131, and accompanying text.
} 
Those truncated rules limit the detail with which competitive effects are analyzed. They may make it unnecessary to examine whether a defendant can or did solve each exclusion problem (in an exclusionary effects case) or each cartel problem (in a collusive effects case), as would be relevant when evaluating the conduct under the comprehensive rule of reason. ${ }^{224}$ The truncated condemnation rule for exclusionary conduct infers harm to competition from evidence that all actual or potential rivals other than insignificant competitors have been excluded through conduct lacking a plausible efficiency justification. If these facts can be demonstrated, the conduct can be found to harm competition by presuming (or inferring) that firms can solve one of their exclusion problems, profitability, without specifically analyzing it. Two of the open questions - the possibility that proof of excluding-firm market power may permit the inference that all rivals are or likely would be excluded from evidence that one has been excluded, and the possibility that harm to competition could be shown through actual effects evidence in a retrospective exclusion case-raise the possibility of presuming (or inferring) that firms can also solve a second exclusion problem, sufficiency, again without specifically analyzing it.

Whether exclusion or collusion is alleged, truncation of the reasonableness review means that adverse competitive effects can be inferred without showing fully why the anticompetitive mechanism worked: why it was profitable in

${ }^{224}$ See, e.g., United States v. Visa U.S.A., Inc., 344 F.3d 229 (2d Cir. 2003) (explicitly analyzing the method of exclusion and its sufficiency, and implicitly analyzing its profitability by recognizing that it protected excluding-firm market power from erosion). A wide range of other evidence could be relevant under the comprehensive rule of reason to determining whether defendants in an exclusionary conduct case have solved their exclusion problems. For example, the availability of potential alternative sources of distribution to an excluded manufacturer may bear on whether the plaintiff was substantially or insignificantly excluded, as may the duration and costs of terminating the exclusivity agreements that limit the excluded firm's access to customers, and the percentage of the market foreclosed to the excluded firm by the conduct at issue may be relevant to assessing the sufficiency of the alleged exclusionary acts to create harm to competition. E.g., Omega Envtl., Inc. v. Gilbarco, Inc., 127 F.3d 1157 (9th Cir. 1997); cf. NicSand, Inc. v. 3M Co., 507 F.3d 442 (6th Cir. 2007) (finding that an excluded rival challenging a dominant manufacturer's multi-year distribution contracts with all major retailers lacked antitrust injury when the excluded rival was formerly dominant, previously had exclusive distribution arrangements with most of the leading retailers, and had an equal opportunity to compete for exclusivity with the new dominant firm). The focus on "coercion" by the excluding firm in a recent appellate decision can be understood either as an aspect of the inquiry into whether the plaintiff has alternatives for avoiding exclusion (an inquiry into "method") or as an aspect of an inquiry into whether the defendant had a legitimate business justification for the practice. Race Tires Am., Inc. v. Hoosier Racing Tire Corp., 614 F.3d 57, 77-79 (3d Cir. 2010). Comprehensive reasonableness analysis of exclusionary conduct is the same regardless of whether the conduct is challenged by the government or an excluded firm or whether the case is brought under Sherman Act Section 1 (as a vertical agreement), Sherman Act Section 2 (as monopolization or an attempt to monopolize), Clayton Act Section 3 (as exclusive dealing), or FTC Act Section 5. See generally HovenKamp, supra note $36, \S 10.9$ (noting that exclusive dealing has been condemned under several statutes). 
both settings, perhaps why the method was sufficient in an exclusion case, and how the firms deterred cheating and prevented new competition in a collusion case. The specific methods by which firms exercise market power differ across the settings, but the burden on plaintiff is reduced in an analogous way in each. Again the formal structure of the truncated doctrinal rule does not treat exclusion differently from collusion.

\section{POLICY CONSIDERATIONS DO NOT JUSTIFY DOWNPLAYING EXCLUSION}

Although the rhetorical consensus for treating exclusion as a lesser offense is commonly asserted without explicit justification, its defenders sometimes argue that false positives (convictions) are more likely or more costly with exclusionary violations than collusive ones, while false negatives (acquittals) are less likely or less costly with exclusion than collusion. ${ }^{225}$ This framing adopts an "error cost" perspective to evaluate antitrust rules, under which the best rule minimizes total social costs. ${ }^{226}$ This general approach toward evaluating legal rules has been employed by the Supreme Court in recent antitrust decisions. ${ }^{227}$

In antitrust applications, the costs to society that need to be considered extend beyond litigation costs and the consequences of alternative decisions to the parties to a case; they also include the benefits (negative costs) of deterring harmful conduct and costs of chilling beneficial conduct, throughout the

\footnotetext{
225 See, e.g., Keith N. Hylton, The Law and Economics of Monopolization Standards, in ANTITRust Law AND ECONOMics 82, 102 (Keith N. Hylton ed., 2010).

226 The relevant social costs are commonly described as the costs of false positives and false negatives, along with the transaction costs associated with the use of the legal process. See DOJ SECTION 2 REPORT (WithDRAWN), supra note 11, at 15-18 (endorsing error cost framework for the evaluation of Section 2 standards). Transaction costs include more than the costs of litigation; they also include costs associated with information-gathering by the institution specifying decision rules. See C. Frederick Beckner III \& Steven C. Salop, Decision Theory and Antitrust Rules, 67 Antitrust L.J. 41 (1999).

${ }^{227}$ See, e.g., Leegin Creative Leather Prods., Inc. v. PSKS, Inc., 551 U.S. 877, 895 (2007); (explaining that per se rules may "increase the total cost of the antitrust system" even when they "decrease administrative costs" if they "prohibit[] procompetitive conduct the antitrust laws should encourage" or "increase litigation costs by promoting frivolous suits against legitimate practices" and overruling rule of per se illegality against vertical price restraints); Verizon Commc'ns Inc. v. Law Offices of Curtis V. Trinko, LLP, 540 U.S. 398, 408 (2004) (describing a need to be "very cautious" in finding an antitrust violation when a dominant firm unilaterally refuses to cooperate with a rival "because of the uncertain virtue of forced information sharing and the difficulty of identifying and remedying anticompetitive conduct by a single firm"); $i d$. at 414 (expressing concern with the "cost of false positives" arising from the possibility that "generalist antitrust court" would need to enforce a complex statutory scheme in a dynamic industry); Brooke Grp. Ltd. v. Brown \& Williamson Tobacco Corp., 509 U.S. 209, 226 (1993) (stating that in predatory pricing cases, "the costs of an erroneous finding of liability are high" because of the danger that false convictions would chill procompetitive price cutting).
} 
economy. ${ }^{228}$ But it can be difficult to account for economy-wide effects within the error cost framework. ${ }^{229}$ Moreover, when deterrence and chilling effects are accounted for, substantive legal rules can properly be compared on the basis of their error costs only if the comparison holds constant a wide range of background institutions: both antitrust enforcement institutions, such as rules governing burdens of proof, ${ }^{230}$ which can vary in impact across doctrinal categories, ${ }^{231}$ and non-antitrust institutions, such as the scope of intellectual property rights. ${ }^{232}$ Notwithstanding these conceptual and practical difficulties, this section will discuss antitrust rules in terms of the familiar categories of false positives and false negatives.

Given that the similarity in the economic reasons for concern about anticompetitive collusion and anticompetitive exclusion, ${ }^{233}$ and the similar structure to the legal rules governing exclusion and collusion, ${ }^{234}$ an error cost argument for downplaying exclusion relative to collusion cannot turn on how conduct would be evaluated by an omniscient judge faithfully applying the rules. Rather, the two leading and closely related policy arguments offered for downplaying exclusion relative to collusion rely on arguments about the relative likelihood and magnitude of mistakes in the antitrust review of collusive conduct compared with exclusionary conduct. The first supposes that it is

${ }^{228}$ See, e.g., Brooke Group, 509 U.S. at 223 (permitting predatory pricing enforcement based on above cost prices would create "intolerable risks of chilling legitimate price-cutting"); Allied Orthopedic Appliances Inc. v. Tyco Health Care Grp., 592 F.3d 991, 1000 (9th Cir. 2010) (noting that courts should not find monopolization when the alleged exclusionary act is a non-sham product design improvement because of the danger of dampening technological innovation and the difficulty of weighing uncertain future benefits against current competitive harms). Deterrence considerations are particularly important in evaluating antitrust rules. See generally Jonathan B. Baker, The Case for Antitrust Enforcement, 17 J. Econ. Persp., Autumn 2003, at 27.

${ }^{229}$ False positives and false negatives may not neatly map onto overdeterrence and underdeterrence, respectively, because the deterrence consequences of legal errors depend in part on the way the errors affect the marginal costs and benefits to firms of taking precautions to avoid violations. See generally Warren F. Schwartz, Legal Error, in ENCYClOPEDIA OF LAW AND ECONomics 1029, 1029-38 (Boudewijn Bouckaert \& Garrit De Geest eds., 1999), available at http:// encyclo.findlaw.com/0790book.pdf.

${ }^{230}$ See generally Louis Kaplow, Burden of Proof, 121 YALE L.J. 738 (2012); Wickelgren, supra note 77, at 54 (noting that the consequences of greater accuracy at trial for firm conduct depend in part on whether firms can predict how trial outcomes will change, whether settlement outcomes are improved, and how decisions to sue or settle are affected).

${ }^{231}$ See Stephen Calkins, Summary Judgment, Motions to Dismiss, and Other Examples of Equilibrating Tendencies in the Antitrust System, 74 Geo. L.J. 1065, 1127-39 (1986) (documenting the way the antitrust treble damages remedy has shaped substantive and procedural antitrust law across doctrinal categories).

${ }^{232}$ The balance of error costs could change if the antitrust rules themselves change, as when the Supreme Court modified many legal rules in response to Chicago School concerns that they impeded efficiency enhancing business conduct, or if the background institutions change even when the rules do not.

${ }^{233}$ See supra Part III.A

${ }^{234}$ See supra Part II.B. 
harder to tell apart harmful and beneficial conduct when exclusion is alleged, so enforcers and courts are more likely to make errors in that setting. ${ }^{235}$ The second contends that false positives are more dangerous when exclusion is alleged because they are more likely to chill beneficial conduct like price cutting and new product introductions-making it more important that enforcers and courts avoid errors in the exclusion setting. ${ }^{236}$ If errors are more frequent and more costly to society when exclusionary conduct is alleged, as these two stories claim, enforcers and courts should be more cautious in challenging such conduct.

The enforcement agencies do challenge anticompetitive collusion more frequently than they challenge anticompetitive exclusion. Since 1980, U.S. cases involving horizontal restraints, a collusion-oriented doctrinal category, have been brought substantially more often than cases in doctrinal categories where exclusion is more likely to be found (monopolization and vertical agreements). ${ }^{237}$ Although this observation may seem to follow from agency views regarding relative error costs, ${ }^{238}$ or even to vindicate that perspective, there is

${ }^{235}$ See Frank H. Easterbrook, When Is It Worthwhile to Use Courts to Search for Exclusionary Conduct?, 2003 Colum. Bus. L. Rev. 345, 345 ("'C]ompetitive and exclusionary conduct look alike."); DOJ SECTION 2 Report (WithDRAwn), supra note 11, at 13 ("[O]ften the same conduct can both generate efficiencies and exclude competitors.").

${ }^{236}$ See Easterbrook, supra note 235, at 347.

${ }^{237}$ See generally Kovacic, supra note 30, at 377. Including Robinson-Patman violations as an exclusion category would not alter this conclusion. The frequency of anticompetitive collusion challenges relative to harmful exclusion allegations in court cases is also likely skewed toward collusion, even though the frequency of court cases is likely driven by private litigation rather than agency enforcement actions. A study of the private treble damages cases filed between 1973 and 1983 in five districts found substantially more raised horizontal allegations (which tend to involve collusive conduct) than vertical allegations (which more often involve exclusionary conduct). See Steven C. Salop \& Lawrence J. White, Treble Damages Reform: Implications of the Georgetown Project, 55 AnTitrust L.J. 73, 74 (1986) (finding that "52.8 percent of cases incorporated vertical allegations [while] 71.6 percent [incorporated]] horizontal allegations"). Many cases included both horizontal and vertical claims, consistent with the possibility that exclusionary conduct was part of a collusive scheme (as can be the case even when the plaintiff is a rival). See, e.g., JTC Petroleum Co. v. Piasa Motor Fuels, Inc., 190 F.3d 775 (7th Cir. 1999). These statistics were not driven by cases brought by standalone competitors, as they accounted for only 22.9 percent of the filings in the sample. See Salop \& White, supra, at 74. The explanations and implications of the disparity in the frequency of the two types of agency cases, discussed below, would also likely apply to the interpretation of the relative frequency of private cases, as private plaintiffs and their attorneys often face a similar cost-benefit calculus as the enforcement agencies in allocating their resources and many private cases are follow-ons to government investigations.

${ }^{238}$ Cf. DOJ Section 2 Report (Withdrawn), supra note 11, at 5, 8 (relying on the U.S experience applying Section 2 to derive broad principles). In recent years, moreover, the agencies may have begun to prioritize collusion in ways that go beyond allocating enforcement resources. The agencies have targeted collusion for increased penalties, greater international cooperation, and the increased use of leniency programs to provide an incentive for colluding firms to come forward. Scott D. Hammond, Deputy Assistant Att'y Gen., U.S. Dep't of Justice, The Evolution of Criminal Antitrust Enforcement Over the Last Two Decades (Feb. 25, 2010), available at http://www.justice.gov/atr/public/speeches/255515.htm; see Stephen Labaton, The 
actually no necessary relationship between the distribution of errors and their costs and the relative frequency of cases. Even if the allocation of agency cases provides a reliable guide to the relative frequency of the two types of competitive problems, the observed enforcement pattern does not mean that errors in resolving antitrust allegations, whether false positives or false negatives, are either more frequent or more costly in exclusion settings. Nevertheless, to evaluate the relative frequency and magnitude of errors, it is useful to first examine why the agencies emphasize collusion over exclusion in case selection.

\section{A. Relative Frequency of Errors}

To begin with frequency, the connection between the relative number of collusion and exclusion challenges and the frequency of errors depends in part on why the agencies bring more collusion cases than exclusion cases. There are a number of possible explanations, including the following four. First, the agencies may bring more collusion cases because the antitrust laws deter anticompetitive exclusion more effectively than they deter anticompetitive collusion. ${ }^{239}$ This explanation makes sense: collusion is likely easier to hide than exclusion; exclusion can often more easily or reliably be achieved through conduct that would not violate the antitrust laws (such as lobbying for governmentally created entry barriers ${ }^{240}$ ); and firms with an incentive to avoid anti-

World Gets Tough on Fixing Prices, N.Y. TIMEs, June 3, 2001, http://www.nytimes.com/2001/ 06/03/business/the-world-gets-tough-on-fixing-prices.html. At the same time, they have debated whether courts should relax the legal rule governing monopolization, which is almost always an exclusionary offense, in order to raise the practical burden on plaintiffs. See supra note 37. By contrast, European competition policymakers tend to express greater concern with exclusionary conduct. See, e.g., Eleanor Fox \& Daniel Crane, Global Issues in Antitrust and CompetiTION LAw 122, 123-29 (2010) (contrasting the EU test for predatory pricing with the "very conservative" approach of U.S. courts); $i d$. at 130 (observing that EU law is more likely to require that a dominant firm deal with its rival than U.S. law); id. at 143 (noting "a significant divide" between the United States and the European Union on using competition policy to address margin squeezes by regulated firms); $i d$. at 197 ("The European Union . . . is less permissive [than U.S. law on vertical restraints].").

${ }^{239}$ Many examples of anticompetitive collusion, exclusion, and mergers have been documented across a range of industries during periods of lax antitrust enforcement, such as the quarter century after the Sherman Act was enacted, suggesting that the antitrust laws have deterred a great deal of anticompetitive conduct. See Baker, supra note 228, at 36-38.

${ }^{240}$ Cf. James C. Cooper, Paul A. Pautler \& Todd J. Zywicki, Theory and Practice of Competition Advocacy at the FTC, 72 ANTITRUST L.J. 1091 (2005) (describing trends in the FTC's competition advocacy program, which questions proposed federal or state legislation and regulations that threaten to impede competition). The Federal Trade Commission has also emphasized the importance of construing the state action exemption to the antitrust laws narrowly in order to discourage the manipulation of regulatory processes for private rent-seeking. See John T. Delacourt \& Todd J. Zywicki, The FTC and State Action: Evolving Views on the Proper Role of Government, 72 ANTITRust L.J. 1075 (2005). 
trust liability may find it easier to prevent managers from harming competition through exclusion than from doing so through collusion. ${ }^{241}$

Second, the agencies may bring more collusion cases because they have chosen to direct the bulk of their investigative resources toward collusion rather than exclusion for reasons of efficiency in budget and personnel allocation rather than because of their perception of the distribution of error costs. They likely find it cost-effective to focus their efforts outside merger review on anticompetitive conduct that lacks a plausible efficiency justification, ${ }^{242}$ and when they do, they likely discover that naked collusion is more common than plain exclusion. ${ }^{243}$

Third, the relative counts of collusion and exclusion cases may overstate the relative frequency of collusion because of the way the cases are counted. The most plausible way this could happen is if mixed cases-cases in which firms both collude and exclude-are not infrequent and are routinely viewed solely as collusion cases. ${ }^{244}$ Under such circumstances, the agencies may appear to be directing their enforcement efforts toward collusion more than they are doing in fact.

These three explanations - greater deterrence of exclusion, agency resource allocation decisions, and treating mixed cases solely as collusion matters-are collectively more likely than the fourth possibility, which is implicitly accepted by those who favor the error cost argument for downplaying exclusion: that collusion cases are more common because it is more difficult to distinguish harmful from beneficial conduct in exclusion settings than in collusion settings. Yet only the fourth explanation tends to suggest that enforcers and courts are more likely to make errors in resolving exclusion allegations than collusion allegations.

Moreover, the fourth explanation is problematic. It is hard to see why the difficulties in identifying harm to competition would be systematically greater in an exclusion setting than a collusion one if the challenged conduct has no

${ }^{241}$ See William H. Page, Optimal Antitrust Remedies: A Synthesis 15-16 (Working Paper 2012), available at http://ssrn.com/abstract $=2061791$.

${ }^{242}$ See Creighton et al., supra note 81, at 995 (recommending that enforcers target cheap exclusion); First, supra note 80, at 160-62 (recommending new remedial tools for attacking monopolization through conduct lacking an efficiency justification).

${ }^{243}$ See Jacobson, supra note 80, at 361 (noting that in the context of vertical exclusive dealing, exclusionary conduct lacking any plausible justification "appears unusually rare"). Even if plain exclusion is no less common than naked collusion, moreover, antitrust cases attacking plain exclusion may be less frequent if exclusionary conduct lacking any plausible business justification is commonly attacked under non-antitrust statutes. See A. Douglas Melamed, Exclusionary Conduct Under the Antitrust Laws: Balancing, Sacrifice, and Refusals to Deal, 20 Berkeley ТЕсH. L.J. 1247, 1249 (2005).

${ }^{244}$ See supra notes 43-48, 149-155 and accompanying text. 
plausible efficiency justification in each case-that is, in a universe limited to naked collusion and plain exclusion. It is also hard to see why the difficulties identifying anticompetitive practices would be greater in an exclusion setting for the rest of the relevant universe-that is, if the challenged conduct does have a plausible efficiency justification in each case.

For example, to pick an exclusionary practice, ${ }^{245}$ a manufacturer's requirement that a retailer not distribute rival manufacturers' products may benefit the manufacturer primarily because the practice creates efficiencies (as by eliminating double marginalization or otherwise aligning incentives between manufacturer and retailer), or it may benefit the manufacturer primarily because the practice confers market power by excluding rival manufacturers from access to low cost distribution. It may be difficult to distinguish between these explanations. But it may equally be difficult to tell whether a retailing joint venture between two manufacturers, to pick a collusive practice, primarily benefits them by lowering production costs (as by generating scale economies) or by conferring market power through a reduction in the direct competition between them. It may also be difficult to tell whether an agreement among rivals to exchange information (perhaps implemented through their trade association) benefits competition by helping the firms match production to costs and demand, or whether it harms competition by facilitating collusion, as by helping them detect cheating rapidly. ${ }^{246}$

The casual but erroneous supposition that it is harder to distinguish harms from efficiencies in the exclusion setting is likely the result of a category mistake: comparing the difficulty of proving harm from naked cartels, where there is no plausible efficiency, with the difficulty identifying anticompetitive exclusionary practices when the conduct has a plausible justification. ${ }^{247}$ Naked cartels probably come first to mind as a collusive practice, given the frequency with which the enforcement agencies announce such cases. But when

${ }^{245}$ No example can be representative, but the argument plausibly generalizes beyond the examples provided here.

${ }^{246}$ For case examples that suggest the difficulty of distinguishing harms to competition and efficiencies when collusion is alleged, see, for example, Broadcast Music, Inc. v. CBS Inc., 441 U.S. 1 (1979) (reversing lower court decision finding a blanket licensing agreement among rival copyright owners illegal per se); United States v. Topco Associates, 405 U.S. 596 (1972) (striking territorial restrictions on the marketing of private label products distributed by a joint venture among supermarkets, some of which were effectively horizontal rivals); General Motors Corp., 103 F.T.C. 374 (1984) (approving joint production venture between rival automakers subject to conditions).

${ }^{247}$ Similarly, it would be inappropriate to make inferences about the relative harm arising from exclusion and collusion by comparing the competitive harm from the typical naked cartel to the competitive harm from the typical instance of exclusionary conduct, whether plain or justified by an efficiency. See Aaron Edlin, Predatory Pricing, in Research Handbook on the Economics of Antitrust Law 144, 173 (Einer Elhauge ed., 2012) ("Presumably, it is true . . that most price cuts are pro-competitive .... However, no antitrust proposals attack all price cuts, so that sample is irrelevant."). 
thinking about exclusion without reflecting on how to make an apples-to-apples comparison, the top-of-mind exclusionary practice will often be a vertical contract with a plausible efficiency justification, rather than an example of plain exclusion, such as the conduct found to violate the antitrust laws in Lorain Journal and Microsoft. The casual supposition misleads because plain exclusion would correspond to a naked cartel, while a vertical contract with a plausible justification would not. A comparison based on a category mistake provides no reason to expect more frequent enforcement and adjudicative errors in resolving exclusion cases than in evaluating collusion cases.

\section{B. Relative Cost of Errors}

For the reasons set forth above, downplaying exclusion cannot be justified based on the view that false positives are more common in the exclusion setting. If a justification remains, it would instead have to be based on a supposition that any errors that do occur are more costly when exclusion is alleged than when collusion is alleged. Two primary arguments have been offered for this latter supposition-one based on empirical studies and the other rooted in an analysis of institutional competence-but neither is convincing.

First, some commentators suggest that the many empirical studies that have identified efficiencies and other competitive benefits from vertical integration and vertical agreements show that anticompetitive consequences of such practices are unlikely, so antitrust rules should favor defendants in exclusionary conduct categories. ${ }^{248}$ But these studies would be probative only if they show that errors are more costly when exclusion is alleged than when collusion is alleged, which they do not. ${ }^{249}$ Many of the cited studies do not discriminate between exclusionary and collusive explanations for vertical agreements; ${ }^{250}$ taken at face value, they would question the prevalence of both explanations and thus cannot provide a basis for downplaying exclusion relative to collusion. ${ }^{251}$ Moreover, the business decisions evaluated in these studies are com-

\footnotetext{
248 Jeffrey Church, Vertical Mergers, in 2 Issues in Competition Law and Policy, supra note 52, at 1455, 1495-97; James C. Cooper, Luke M. Froeb, Dan O’Brien \& Michael G. Vita, Vertical Antitrust Policy as a Problem of Inference, 23 InT'L J. Indus. ORg. 639 (2005); Geoffrey A. Manne \& Joshua D. Wright, Innovation and the Limits of Antitrust, 6 J. CoMPETITION L. \& ECON. 153, 161 n.23 (2010).

${ }^{249}$ The studies do not bear on the relative frequency of errors, so also do not show that false positives would be more frequent in exclusion cases than collusion cases.

${ }^{250}$ Cf. Leegin Creative Leather Prods., Inc. v. PSKS, Inc., 551 U.S. 877, 892-94 (2007) (discussing both collusive and exclusionary explanations for resale price maintenance).

${ }^{251}$ The prevention or elimination of free riding can potentially justify both vertical and horizontal agreements. Cont'l T.V., Inc. v. GTE Sylvania Inc., 433 U.S. 36 (1977) (vertical non-price agreement); Polk Bros., Inc. v. Forest City Enters., Inc., 776 F.2d 185 (7th Cir. 1985) (horizontal market division agreement between potential rivals). "Free riding" refers to the externality that arises when investments by one firm increase demand or reduce costs for rivals, and the first firm is not compensated for providing this benefit. The elimination of free riding is frequently in-
} 
monly made under the shadow of the antitrust laws. Because of the deterrent effect of antitrust enforcement, the observed practices would be expected disproportionately to benefit competition even if they have anticompetitive potential in other settings. ${ }^{252}$ In consequence, empirical studies evaluating exclusionary conduct provide little evidence of value regarding either the potential for those practices to harm competition ${ }^{253}$ or the likelihood that the particular instances selected for enforcement in fact harm competition. ${ }^{254}$

The other commonly offered justification for the view that errors are more costly when exclusion is alleged than when collusion is alleged turns on a claim about the institutional competence of enforcers and courts. For institutional competence to matter, enforcers and courts must make systematically

voked to justify restrictions imposed by manufacturers on distributors, where the manufacturer claims that absent the restrictions, the dealer would not provide an appropriate level of services to customers or promotional investments. See generally Benjamin Klein \& Andres V. Lerner, The Expanded Economics of Free-Riding: How Exclusive Dealing Prevents Free-Riding and Creates Undivided Loyalty, 74 Antitrust L.J. 473 (2007); Benjamin Klein \& Kevin M. Murphy, Vertical Restraints as Contract Enforcement Mechanisms, 31 J.L. \& Econ. 265 (1988); Lester G. Telser, Why Should Manufacturers Want Fair Trade? 3 J.L. \& Econ. 86 (1960). For other examples of business justification defenses considered in antitrust cases, see HovenKaMP, supra note 36, § 5.2 (horizontal joint ventures); Mary Anne Mason \& Janet L. McDavid, Business Justification Defenses, in 2 Issues in Competition Law and Policy supra note 52, at 1019 (monopolization cases); Michael A. Salinger, Business Justification Defenses in Tying Cases, in 3 Issues in Competition Law And Policy supra, at 1911 (tying cases); Joseph Kattan, Efficiencies and Merger Analysis, 62 ANTitrust L.J. 513 (1994) (horizontal mergers).

${ }^{252}$ See Wickelgren, supra note 77, at 55 ("[H]ow often one should expect to see an anticompetitive manifestation of a restraint will depend on how that restraint is likely to be judged."); $i d$. at 56 ("When considering whether to change the treatment of RPM, for example, from the per se rule to the rule of reason, it is not important what fraction of existing uses of RPM are pro- or anticompetitive. Rather, what matters is how many more pro- and anticompetitive instances of RPM will arise under some version of rule-of-reason treatment rather than per se treatment."). Relatedly, the leading studies of vertical restraints may have examined competitive effects primarily in relatively competitive markets, where those practices would not be expected to harm competition, rather than in sectors in which firms exercise substantial market power, where antitrust enforcement tends to be concentrated. Vincent Verouden, Vertical Agreements: Motivation and Impact, in 2 Issues in Competition Law AND Policy, supra note 52, at 1813, 1837. Although defendants commonly prevail in vertical restraint cases, those outcomes frequently result from lack of proof of market power so they provide little guide to the likelihood that such conduct, whether exclusionary or collusive, would be justified when defendants have market power. Furthermore, the prevalence of a practice in markets thought to perform competitively at best establishes that the practice could be procompetitive. It does not indicate whether the conduct could harm competition when employed by firms with market power or whether anticompetitive uses have been deterred by the threat of antitrust enforcement. See Randal D. Heeb et al., supra note 153 , at 229 (loyalty rebates, which in theory can under some circumstances benefit competition and under other circumstances harm competition, are sometimes used by cartels).

${ }^{253}$ Empirical economic studies about the competitive effects of specific business practices are generally more useful for evaluating conduct in industries similar to those studied than for generalizing across industries to formulate legal rules. Jonathan B. Baker \& Timothy F. Bresnahan, Economic Evidence in Antitrust: Defining Markets and Measuring Market Power, in HandBook of Antitrust Economics 1, 24-29 (Paolo Buccirossi ed., 2008).

${ }^{254}$ By contrast, the many examples of anticompetitive conduct observed during periods of lax antitrust enforcement suggest the benefits of antitrust. See Baker, supra note 228, at 36-38. 
different (and worse) errors when evaluating exclusion cases than when analyzing collusion cases. Because the main concern of those arguing in favor of downplaying exclusion is that false positives will chill procompetitive conduct, the issue turns on the relative incidence and significance of judicial errors when the conduct under review has a plausible efficiency justification. In the exclusion context, this includes price cutting and new product introductions-conduct that at least in the short run benefits consumers. ${ }^{255}$ There is no reason to think that enforcers and courts will systematically fail to notice when defendants have a plausible efficiency justification in exclusion cases yet recognize that possibility in collusion cases. ${ }^{256}$ If outcomes are systematically biased in favor of plaintiffs in exclusion cases but not in collusion cases, that outcome would instead have to result from some aspect of the decisionmaking process that differs across the two settings.

The most common institutional competence argument presumes that exclusion cases are disproportionately prompted by the trumped up complaints of inefficient rivals, losers in the marketplace, that seek to overturn the market's verdict in the courts directly as plaintiffs or indirectly by inducing enforcement agency suits. If so, and if, in addition, complaining rivals bringing bad cases tend to have more influence over the judicial process than the firms wrongly accused of anticompetitive exclusionary conduct, then false positives would be more likely to arise in exclusion cases than in collusion cases. ${ }^{257}$

\footnotetext{
255 Similarly, collusive conduct can appear to benefit consumers in the short run. Examples may include various practices facilitating coordination, such as the parallel adoption of simplified and common product definitions, the parallel adoption of price lists, or the parallel adoption of guarantees to buyers that they will get the best price the seller gives any buyer.

${ }^{256}$ To similar effect, some claim that antitrust enforcement against exclusion is problematic because it is difficult for courts to make the detailed factual assessments required to determine whether firms can solve their exclusion problems or to compare the harms from exclusionary conduct against the procompetitive benefits. See, e.g., Manne \& Wright, supra note 248, at 157 (characterizing Easterbrook's analysis as premised in part on the view that "errors of both types are inevitable, because distinguishing procompetitive conduct from anticompetitive conduct is an inherently difficult task in the single firm context"). Yet if fact finding is the problem with comprehensive reasonableness review of exclusion allegations, it raises a comparable difficulty for collusion enforcement under the comprehensive rule of reason, where a court must determine whether firms can solve their collusion problems and analyze whether the benefits to competition dissipate or eliminate the harms. See Leegin Creative Leather Prods., Inc. v. PSKS, Inc., 551 U.S. 877, 916-17 (2007) (Breyer, J., dissenting) (noting the difficulties of assessing whether the benefits of resale price maintenance in preventing free riding outweigh the potential harm of facilitating a dealer cartel, and the difficulties judges and juries may face in evaluating market power).

257 See, e.g., William J. Baumol, Robert E. Litan \& Carl J. Schramm, Good Capitalism, Bad Capitalism, and the Economics of Growth and Prosperity 118-19 (2007); Edward A. Snyder \& Thomas E. Kauper, Misuse of the Antitrust Laws: The Competitor Plaintiff, 90 Mich. L. REv. 551 (1991) (noting that a small minority of the 37 horizontal restraints cases filed by competitor plaintiffs between 1973 and 1983 in five federal districts alleging exclusionary practices seemed meritorious). If the courts do not weed out false claims from competitors, moreover, even efficient rivals would be expected to bring unwarranted exclusion claims in order to discourage hard competition from dominant firms.
} 
Under such circumstances, antitrust institutions would inappropriately tend to protect competitors rather than competition in exclusion cases, but not so often in collusion cases, consistent with what those making this institutional competence argument contend. ${ }^{258}$

This argument about institutional competence is unconvincing, however, because there is no reason to think that the agencies and courts are biased in favor of the victims of alleged exclusion ${ }^{259}$ or that unsuccessful rivals can systematically convince the enforcement agencies and courts to accept bad cases. ${ }^{260}$ Even if unsuccessful rivals or terminated dealers foresee the possibility of substantial gains from bringing a speculative (or even trumped up) antitrust complaint, they must also consider their low probability of success in evaluating their expected gain, and thus in deciding whether to bring a case. After all, it is no more difficult for enforcers and courts to understand the possible biases of rivals, and discount their testimony appropriately, than for those decision makers to discount as necessary the testimony of alleged excluding firms and customers. ${ }^{261}$ More than most firms, moreover, defendants in exclusion cases, particularly large firms accused of monopolization, tend to have the ability to present an effective courtroom case, employing top quality legal representation and economic experts and supporting them with a generous budget. ${ }^{262}$ Large firm defendants in exclusion cases also tend to have the resources to make an effective public relations case and mobilize political support. $^{263}$

${ }^{258}$ See Brunswick Corp. v. Pueblo Bowl-O-Mat, Inc., 429 U.S. 477, 488 (1977) (quoting Brown Shoe Co. v. United States, 370 U.S. 294, 320 (1962) (noting that antitrust aims to protect "competition, not competitors")).

${ }^{259}$ One commentator speculates, without evidence, that antitrust enforcers tend to sympathize with smaller firms. D. Daniel Sokol, The Strategic Use of Public and Private Litigation in Antitrust as Business Strategy, 85 S. CAL. L. Rev. 689, 730-31 (2012). It is also possible that juries could systematically misinterpret colorful evidence of defendant intent to crush rivals as indicating an aim to do so through anticompetitive means (rather than by lowering costs and prices or introducing new or better products), notwithstanding jury instructions making the relevant distinction. The likelihood and magnitude of the possible prejudicial effect of such evidence on the interpretation of aggressively competitive conduct close to the line is hard to assess, but if this possibility is important systematically, it is better addressed through rulings on the admissibility of evidence in those cases where the problem may arise rather than through caution in enforcing the antitrust laws against anticompetitive exclusion generally.

${ }^{260}$ In addition, the antitrust injury requirement limits the possible misuse of the antitrust laws in this way.

${ }^{261}$ See FCC, StafF Analysis and Findings, WT Docket No. 11-65, 44-45 \& n.255 (Nov. 29, 2011), available at http://hraunfoss.fcc.gov/edocs_public/attachmatch/DA-11-1955A2.pdf (describing interests of merging firms and merger opponents and their possible alignment with the public interest).

262 But see Sokol, supra note 259, at 731 (arguing that dominant firms do not employ effective counterstrategies because they are prone to inertia, focused on running their business, arrogant, and likely to be viewed as unsympathetic victims).

${ }^{263}$ Another institutional competence argument concerns remedy. Exclusionary violations are sometimes said to be difficult to remedy in rapidly changing industries, where dramatic changes 


\section{Other Error Cost Arguments}

Other error cost arguments for giving priority to collusion over exclusion are also unconvincing. Some suggest, consistent with Justice Scalia's Trinko dicta, ${ }^{264}$ that false negatives are limited in antitrust cases because markets are almost invariably self-correcting ${ }^{265}$ or that false positives are particularly expensive to society because market power rather than competition forms the primary spur to innovation. ${ }^{266}$ Those controversial claims should not be accepted. ${ }^{267}$ Market power is often durable: economic theory suggests many reasons why monopoly power would not be transitory, ${ }^{268}$ and the case law offers many examples of durable market power, ${ }^{269}$ including in high-tech markets. ${ }^{270}$ Moreover, the empirical evidence indicates that the push of competition is generally more important for innovation than the pull of monopoly. ${ }^{271}$ Hence a focus on "dynamic competition" does not justify exclusionary conduct like monopolization. ${ }^{272}$ For the present discussion, however, the more important

in the marketplace are likely to occur between the date of violation and the time a court determines liability and crafts relief. Even when remedies that would restore competition in the market under review appear limited, however, remedies providing general deterrence (such as fines and damages) remain available. See United States v. Microsoft Corp., 253 F.3d 34, 49 (D.C. Cir. 2001); Louis Kaplow, An Economic Approach to Price Fixing, 77 AntrTrust L.J. 343, 416-32 (2011) (preferring fines to injunctions as the sanction for collusion on general deterrence grounds).

${ }^{264}$ See supra notes 12-20 and accompanying text.

${ }^{265}$ See, e.g., Fred S. McChesney, Easterbrook on Errors, 6 J. Competition L. \& Econ. 11, 16 (2010); Fred S. McChesney, Talking 'Bout My Antitrust Generation: Competition for and in the Field of Competition Law, 52 Emory L.J. 1401, 1412 (2003); see also Hylton, supra note 225, at 102; Manne \& Wright, supra note 248, at 157 (claiming that Easterbrook's analysis is premised in part on the view that "false positives are more costly than false negatives, because self-correction mechanisms mitigate the latter but not the former").

${ }^{266}$ See Evans \& Hylton, supra note 166, at 203.

${ }^{267}$ For a discussion of other arguments potentially related to the balance of error costs in the context of monopolization enforcement, see Baker, supra note 21, at 616-20.

${ }^{268}$ See, e.g., Ariel Ezrachi \& David Gilo, Are Excessive Prices Really Self-Correcting? 5 J. COMPETITION L. \& ECON. 249 (2008) (noting that supracompetitive prices only attract entry efforts if they signal that the post-entry price would be high or that the incumbent firms have high costs, and even then entry may not succeed in competing those prices down to competitive levels); see also Oliver E. Williamson, Delimiting Antitrust, 76 Geo. L.J. 271, 289 (1987) ("Economies as an antitrust defense excepted, no one has provided a demonstration that the cost differences are as Easterbrook indicates. Easterbrook has an undischarged burden of proof that the cost of false positives in the market power region where strategic behavior is implicated is similarly low.").

${ }^{269}$ See, e.g., Standard Oil Co. v. United States, 221 U.S. 1 (1911); United States v. Dentsply Int'l, Inc., 399 F.3d 181 (3d Cir. 2005).

270 See, e.g., United States v. Microsoft Corp., 253 F.3d 34 (D.C. Cir. 2001).

271 See generally Baker, supra note 141; Shapiro, supra note 141.

272 Baker, supra note 166; cf. Catalano, Inc. v. Target Sales, Inc., 446 U.S. 643, 649 (1980) (rejecting the argument that the potential for supracompetitive prices to induce entry could justify horizontal price fixing). Moreover, the suggestion that an increased financial reward to defendants promotes competition by increasing their incentive to invest and innovate, if offered without qualification or recognition of tradeoffs, has no logical stopping point. It would imply that the 
point is that even if these suspect claims were accepted, they would not justify the rhetorical consensus prioritizing collusion: they would be reasons to oppose all antitrust enforcement, not to downgrade exclusion relative to collusion.

Another error cost argument has been accepted by some U.S. courts as a reason to allow a monopolist to make exclusive vertical agreements: the claim that exclusionary practices cannot make matters worse (and thus cannot harm competition) because there is a "single monopoly profit." 273 This possibility does not justify treating exclusion less seriously than collusion, however, because the argument applies only in narrow circumstances. ${ }^{274}$ If the excluding firms have literally no fringe rivals and face no potential entrants, and if there are no ways that buyers can substitute away from the monopoly, then there may indeed be no way to increase the rents from exercising market power through (further) exclusionary conduct. Outside of such unusual facts, though, firms can potentially obtain, extend, or maintain their market power through exclusionary conduct that suppresses these forms of competition, ${ }^{275}$

government should subsidize firms heavily, allowing them to invest even more for the benefit of society. See Hylton \& Lin, supra note 167, at 258-59 (noting that exclusionary practices can encourage investment by making it more profitable).

${ }^{273}$ E \& L Consulting, Ltd. v. Doman Indus. Ltd., 472 F.3d 23 (2d Cir. 2006); G.K.A. Beverage Corp. v. Honickman, 55 F.3d 762, 767 (2d Cir. 1995); Town of Concord v. Boston Edison Co., 915 F.2d 17, 23, 32 (1st Cir. 1990) (Breyer, C.J.); see Jefferson Parish Hosp. Dist. No. 2 v. Hyde, 466 U.S. 2, 36-37 (1984) (O’Connor, J., concurring).

${ }^{274}$ Similarly, a horizontal agreement with no efficiency justification would not harm competition if the horizontal rivals are already coordinating perfectly. But this unlikely possibility does not justify downplaying the concern with collusive conduct.

275 See generally Antitrust Law in Perspective, supra note 25, at 417-18 (example in which a monopolist manufacturer harms competition by consolidating distribution in one dealer); id. at 861-65 (example in which single monopoly profit theory holds when downstream buyer uses monopolized product in fixed proportions with other inputs but fails to hold when the product is used in flexible proportions); id. at 811-12 (example in which a monopolist achieves additional market power through the exclusionary effect of tying); see also Timothy F. Bresnahan, Monopolization and the Fading Dominant Firm, in Competition Law and Economics: Advances in Competition Policy Enforcement in the EU and North America 264 (Abel M. Mateus \& Teresa Moreira eds., 2010) (demonstrating that a dominant firm threatened by rival innovation can profit by blocking those rivals, leading to the failure of the single monopoly profit theory in the case of technologically dynamic industries). An incumbent monopolist would also be unable to increase its market power through exclusion in an unusual case in which it has sufficient bargaining power to permit efficient entry while appropriating virtually all the rents. See Phillipe Aghion \& Patrick Bolton, Contracts as a Barrier to Entry, 77 Aм. Econ. Rev. 388 (1987) (discussing a model in which the manufacturer and distributor seek to allow efficient entry and extract all the rents the entrant creates, but bargaining over splitting the surplus can break down when the parties have imperfect information). The economics literature has also considered the applicability of the "single monopoly profit" argument in the context of "monopoly leveraging" concerns outside the scope of the present discussion. See generally Patrick Rey \& Jean Tirole, A Primer on Foreclosure, in 3 Handbook of Industrial Organization 2145, 2182-83 (Mark Armstrong \& Robert Porter eds., 2007) (discussing models of "horizontal foreclosure"); Salop \& Romaine, supra note 218, at 623-26 (distinguishing between application of 
even if the excluded firms are less efficient competitors than the excluding firms. ${ }^{276}$

In sum, the policy (or error cost) arguments for downplaying exclusion do not stand up to analysis, whether they are grounded in common ideas about the difficulty of distinguishing procompetitive conduct from anticompetitive exclusion or in the more controversial arguments made in Trinko. The close relationship between the ways by which exclusion and collusion allow firms to exercise market power, and the convergence in the legal rules governing exclusionary and collusive conduct, do not mislead. Exclusion should be treated as seriously as collusion.

\section{IMPLICATIONS FOR ENFORCEMENT}

Exclusion should be recognized as a core concern of competition law and policy along with collusion, and the use of the common rhetorical convention that treats anticompetitive exclusionary conduct as of lesser importance than anticompetitive collusion should be avoided. Doing so could lead enforcers to place a higher priority on challenging exclusion than they do today, particularly aiming to prevent exclusionary conduct that forecloses potential entry in markets subject to rapid technological change. It is particularly important to reaffirm the innovation benefits of antitrust enforcement against anticompetitive exclusion in high-tech markets in the wake of the Trinko opinion's nod toward monopoly power as a means of encouraging innovation, ${ }^{277}$ which risks leading lower courts astray. ${ }^{278}$

Recognizing exclusion as a core competition problem is unlikely to lead courts to modify the substantive antitrust rules they employ to test exclusionary conduct. Those rules are, in general, well-designed to test the reasonableness of firm conduct, whether the analysis is truncated or comprehensive. Nor is rhetorical parity likely to affect the frequency with which the courts address exclusionary conduct. Because the rules would not change, it is unlikely that private plaintiffs, which account for the bulk of antitrust litigation, would bring more exclusion cases (other than follow-ons in the event government actions against exclusionary conduct increase). ${ }^{279}$ Government enforcers

\footnotetext{
the "single monopoly profit" argument to monopoly leveraging allegations and preserving monopoly allegations).

276 See supra note 189.

277 See supra note 16 and accompanying text.

${ }^{278}$ See supra notes $167-172$ and accompanying text.

${ }^{279}$ Neither the relative frequency of the underlying anticompetitive conduct nor the tools available to enforcers and plaintiffs for identifying them would directly be affected if exclusion is no longer described as a lesser antitrust offense. The number of exclusion cases could even decline. To the extent firms today have been misled by the common rhetoric, and incorrectly believe that anticompetitive exclusionary conduct would not successfully be challenged, a rhetorical change
} 
should treat exclusionary conduct as comparable in priority with collusive conduct, although, as a practical matter, the relative frequency of government cases alleging anticompetitive exclusion would increase only to the extent the enforcement agencies shift resources away from investigating and challenging anticompetitive collusion. ${ }^{280}$ Even if the agencies targeted exclusionary conduct aggressively, budgetary and staffing limitations would most likely permit the agencies to bring only a handful of additional exclusion cases annually. ${ }^{281}$

The major benefit of recognizing that exclusion is as important as collusion would instead come from protecting the legitimacy of the antitrust rules governing exclusionary conduct against pressure for modifications that would limit enforcement inappropriately. Enforcers and courts would not be misled by the contemporary consensus in antitrust discourse that shies away from attacking anticompetitive exclusion, instead urging a focus on collusive conduct. A rhetorical shift may also heighten the salience of addressing the open questions in the formulation of the rules governing truncated condemnation of anticompetitive exclusion, ${ }^{282}$ and thereby encourage the further development of the law in that area.

A shift in how exclusion is viewed could also matter for remedies, as it may encourage the Justice Department to raise the penalties for anticompetitive exclusionary conduct, in appropriate cases, through criminal enforcement. ${ }^{283}$ The Justice Department has the discretion to challenge anticompetitive exclusionary conduct as a civil violation or to prosecute it criminally, in the same way that the government has the discretion to attack collusion civilly or crimi-

of course could increase deterrence, reduce the prevalence of such conduct, and, in consequence, reduce the frequency with which it is challenged.

${ }^{280}$ The frequency of government enforcement in various categories is surveyed in Kovacic, supra note 30 , at $407-76$.

${ }^{281}$ In recent years, the Justice Department has brought between two and five non-merger civil actions annually and challenged twelve to twenty mergers during each of the least five years (fiscal years 2007-2011), Antitrust Div., U.S. Dep't OF Justice, Workload Statistics FY 2002-2011, http://www.justice.gov/atr/public/workload-statistics.html, and so has limited ability to increase the number of exclusion cases through reallocation of civil resources. The Antitrust Division also filed between forty and ninety criminal cases annually during these years. Because criminal exclusionary conduct cases are likely to be rare even if exclusion is viewed as having equal priority as collusion, the Justice Department is unlikely to be able to increase its exclusionary conduct case count substantially without shifting resources from criminal to civil investigations. The Federal Trade Commission would similarly have only limited ability to increase the number of exclusion cases through reallocation of resources.

${ }^{282}$ See generally supra notes $117-138$ and accompanying text.

${ }^{283}$ The penalties could also be raised by awarding the government the ability to collect civil fines for antitrust violations. See First, supra note 80, at 153-65 (recommending that Congress enlarge government antitrust remedies to include civil penalties, and that the enforcement agencies initially target the use of those remedies to monopolization cases in which the exclusionary conduct had no efficiency justification or in which the defendant engaged in a systemic effort to maintain monopoly). 
nally. ${ }^{284}$ Criminal enforcement has been employed to attack exclusion in the past, as with a monopolization case brought against a dominant newspaper and its senior officials alleging exclusionary conduct similar to the anticompetitive practices attacked in Lorain Journal. ${ }^{285}$ Today, however, criminal antitrust enforcement is directed at cartel conduct, ${ }^{286}$ consistent with the common description of exclusion as a lesser offense.

If exclusion is viewed as central to antitrust, criminal prosecution would no longer be reserved for collusive conduct. When applied to exclusionary conduct, it would almost surely be directed at the most egregious cases of plain exclusion, in much the way that the government now targets only the most egregious naked cartels for indictment. ${ }^{287}$ It would be easy to imagine a criminal antitrust indictment (as well as other criminal charges) brought against senior executives if, for example, a dominant firm harmed competition by

${ }^{284}$ The Justice Department challenged the lysine cartel criminally, for example, but brought a civil case when challenging price fixing among the major airlines. Compare United States v. Andreas, 216 F.3d 645, 680 (7th Cir. 2000) (upholding criminal convictions of executives conspiring to fix lysine prices), with United States v. Airline Tariff Publ'g Co., No. 92-2854 (SSH), 1994 WL 502091 (D.D.C. Aug. 10, 1994) (final consent decree settling airline price-fixing allegations).

${ }^{285}$ Kansas City Star v. United States, 240 F.2d 643 (1957); see also United States v. Hilton Hotels Corp., 467 F.2d 1000 (9th Cir. 1972) (upholding criminal conviction of firms that conspiring to boycott suppliers, though the group boycott was collusive rather than exclusionary); William E. Kovacic, The Intellectual DNA of Modern U.S. Competition Law for Dominant Firm Conduct: The Chicago/Harvard Double Helix, 2007 Colum. Bus. L. Rev. 1, 17-18 \& n.44 (identifying three criminal monopolization cases brought during the early 1960s). Only a small fraction of antitrust cases prosecuted criminally have involved exclusionary practices. See Joseph C. Gallo et al., Criminal Penalties Under the Sherman Act: A Study of Law and Economics, 16 REs. IN L. \& ECON. 25, 28 (Richard O. Zerbe, Jr. ed., 1994) (finding that 33, or 2 percent, of the 1,522 criminal antitrust cases brought by the Justice Department between 1955 and 1993 involved exclusionary practices).

286 "In general, current [Antitrust] Division policy is to proceed by criminal investigation and prosecution in cases involving horizontal, per se unlawful agreements such as price fixing, bid rigging, and customer and territorial allocations. ... [C]ivil prosecution is used with respect to other suspected antitrust violations ...." U.S. Dep' t. of Justice, Antitrust Division MANuAL III-12 (5th ed. Nov. 2010), available at http://www.justice.gov/atr/public/divisionmanual/ atrdivman.pdf.; accord, Thomas O. Barnett, Assistant Att'y Gen., Antitrust Div., U.S. Dep't of Justice, Criminal Enforcement of Antitrust Laws: The U.S. Model (Sept. 14, 2006), available at http://www.justice.gov/atr/public/speeches/218336.htm ("[T]he Division focuses its criminal enforcement . . . . narrowly on price fixing, bid-rigging, and market allocations, as opposed to the 'rule of reason' or monopolization analyses used in civil antitrust law."). In the past, however, the Antitrust Division has indicated that criminal enforcement is appropriate when predatory (exclusionary) conduct supports collusion. See Report of the AtTorney General's National Committee to Study the Antitrust Laws 350 (1955) (statement of Assistant Attorney General).

${ }^{287}$ See Kovacic, supra note 30, at 416-23 (describing the progressive evolution of the U.S. norm treating cartel behavior as criminal conduct since the $1970 \mathrm{~s}$, and providing statistics concerning the relative frequency of criminal (DOJ) and civil (FTC) enforcement against anticompetitive horizontal agreements). See generally Donald I. Baker, To Indict or Not to Indict: Prosecutorial Discretion in Sherman Act Enforcement, 63 Cornell L. Rev. 405 (1978). 
destroying its key rival's factory, ${ }^{288}$ or if a price-fixing cartel engaged in cooperative conduct to exclude an actual or potential rival that threatened to destabilize its collusive arrangement. ${ }^{289}$ Criminal enforcement in exclusion cases would be rare-cartel cases would surely remain the mainstay of the Justice Department's criminal enforcement efforts-but that is not a reason to avoid criminal sanctions in appropriate exclusionary conduct cases.

\section{CONCLUSION}

Enforcers and commentators routinely describe anticompetitive exclusion as a lesser offense than anticompetitive collusion. The absence of rhetorical parity misleads because the two types of conduct harm competition in similar ways and are treated comparably in the framing of antitrust rules. Nor do policy considerations, whether or not discussed in "error cost" terms, suggest downplaying exclusion relative to collusion in antitrust enforcement.

The rhetorical relegation of anticompetitive exclusion to antitrust's periphery must end. The more that exclusion is described as a lesser offense, the more its legitimacy as a subject for antitrust enforcement will be undermined and the greater the likelihood that antitrust rules will eventually change to limit enforcement against anticompetitive foreclosure when they should not. It is time to recognize that exclusion, like collusion, is at the core of sound competition policy.

\footnotetext{
${ }^{288}$ See supra note 55 (providing examples of egregious exclusionary conduct, including destruction of a rival's in-store displays, espionage and sabotage, false statements disparaging a rival's product, and destruction of a rival's retail store); see also United States v. Empire Gas Corp., 537 F.2d 296, 298 \& n.1 (8th Cir. 1976) (involving a corporate president acquitted in criminal case alleging destruction of property; the Justice Department also brought an unsuccessful attempt to monopolize case against the firm).

${ }^{289}$ The moral condemnation and loss of liberty associated with criminal sanctions would thus be limited to the perpetrators of serious anticompetitive conduct that firms and their managers should have understood in advance would be subject to criminal prosecution.
} 